\title{
VIEWS OF EGYPT BY GEORGIOS AND CONSTANTINOS ZANGAKI: EXAMINING A LATE NINETEENTH-CENTURY PHOTOGRAPHIC ALBUM AT THE ART GALLERY OF ONTARIO
}

\author{
by \\ Serra Erdem \\ Bachelor of Fine Arts, Photography \\ The Ontario College of Art \& Design \\ Toronto, Ontario, Canada 2006
}

\begin{abstract}
A thesis presented to Ryerson University, the Art Gallery of Ontario and George Eastman House International Museum of Photography and Film in partial fulfillment of the requirements for the degree of Master of Arts in the program of Photographic Preservation and Collections Management
\end{abstract}

Toronto, Ontario, Canada

cSerra Erdem 2009 


\section{DECLARATION}

I hereby declare that I am the sole author of this thesis.

I authorize Ryerson University, the Art Gallery of Ontario and George Eastman House International Museum of Photography and Film to lend this thesis to other institutions or individuals for scholarly research.

I further authorize Ryerson University to reproduce this thesis by photocopying or other means, in total or in part, at the request of other institutions or individuals for the purpose of scholarlv research 


\section{ABSTRACT}

\section{Serra Erdem}

Master of Arts, Photographic Preservation and Collections Management Ryerson University, Art Gallery of Ontario and George Eastman House 2009

This thesis focuses on Views of Egypt, an album housed in the Art Gallery of Ontario, that contains forty-six albumen prints of which twenty-seven are made by two Greek brothers: Georgios (ca.1845-ca.1895) and Constantinos (ca.1845-1916) Zangaki. The Zangaki brothers worked as commercial photographers in the late nineteenth century in the Levant. Considering the extensive number of prints by the Zangaki brothers in various institutions worldwide, they must have been successful; yet neither they nor their photographs are well known. Views of Egypt is part of a larger enterprise: late nineteenthcentury photography in Egypt that aimed at supplying Oriental scenes and picturesque views to the Western tourist. The Zangaki brothers' photographs are representative of this period and merit closer examination. Furthermore, as it is important to preserve such examples, the last part of the thesis considers the preservation of both the album and the photographs it contains. 


\section{ACKNOWLEDGEMENTS}

I would like to thank Marta Braun, Photographic Preservation and Collections Management Program Director and my thesis advisor for spending more time in commenting on my writing, as I was also trying to get a better hang of writing in English, my second language. I would also like to thank my second reader Sophie Hackett, Assistant Curator of Photography at the Art Gallery of Ontario, for her guidance with this project.

Special thanks to Maria Golia, David Harris, Ken Jacobson, Mark Osterman, Engin Özendes, Ola Seif, Maia Sutnik, Carole Troufléau, Katharine Whitman and Alkis X. Xanthakis whose expertise in photography contributed to the development of ideas throughout this thesis project.

I wish to thank the following institutions for granting me access to their photography collections: Art Gallery of Ontario, Département des Estampes et de la Photographie at the Bibliothèque nationale de France, and Photographic and Cinema Collections in Rare Books and Special Collections Library at the American University in Cairo.

Warm thanks to the following individuals: My colleagues from the Art Gallery of Ontario for their friendship and support, Emily McKibbon for photographing the Zangaki brothers' images and providing me with their catalogue information from the Getty Research Institute, Myrto Koumarianos for translating Greek articles, Fusun Uzun for translating French titles, and to Norah Franklin and Amit Dahan for editing this thesis.

Ultimately, I am grateful to my family for their love and support throughout my life. 


\section{TABLE OF CONTENTS}

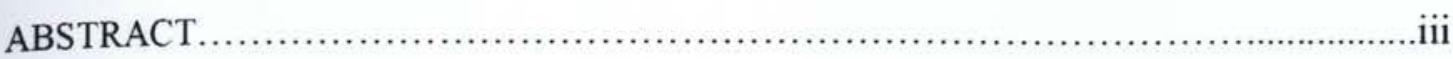

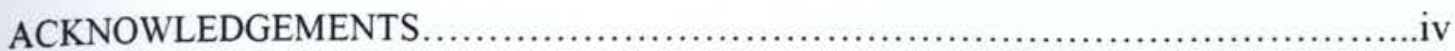

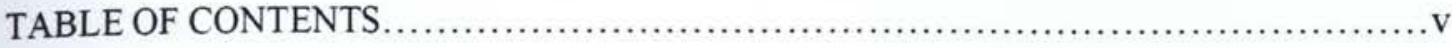

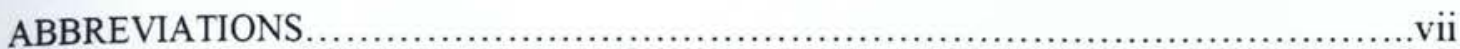

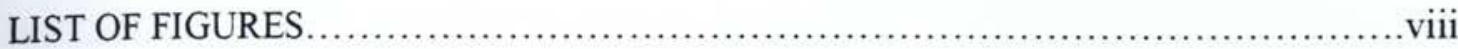

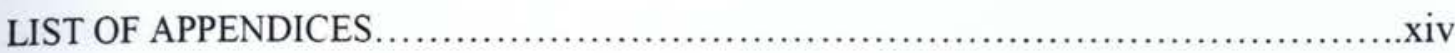

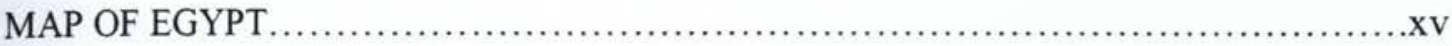

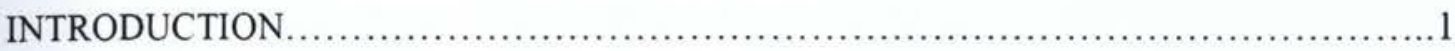

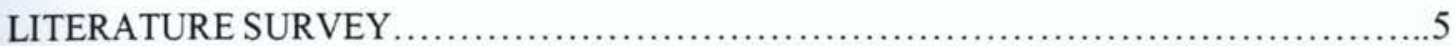

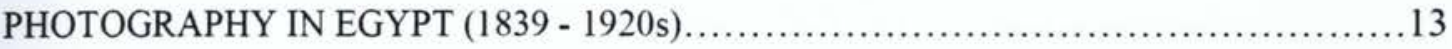

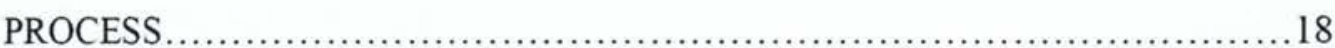

ADDING TEXT TO NEGATIVES...............................................22

POSTCARD PRODUCTION........................................... 23

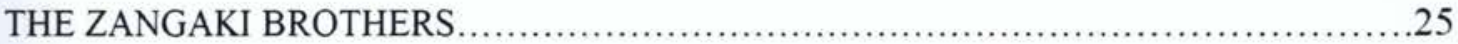

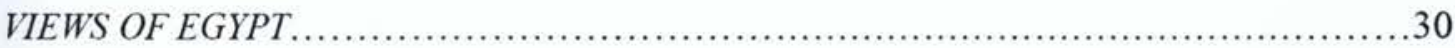

CONSTRUCTION OF THE NEGATIVE LIST ..................................................33

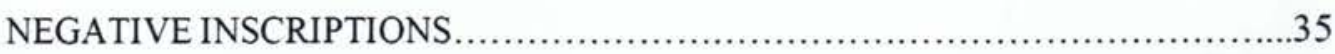

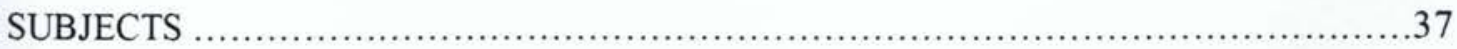

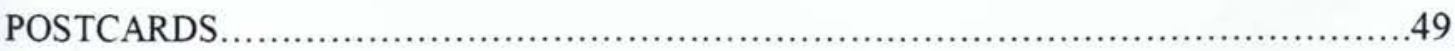

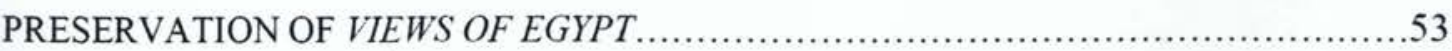

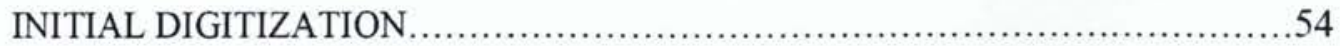

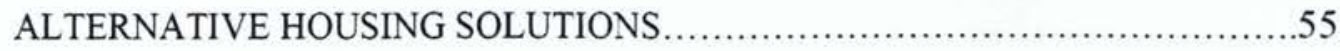




\section{TABLE OF CONTENTS (continued)}

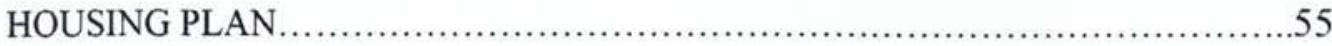

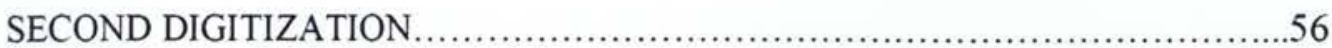

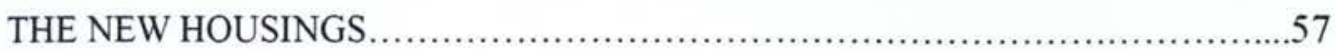

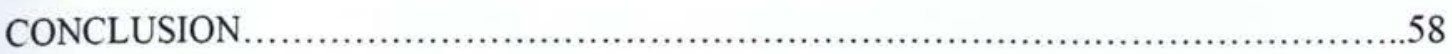

BIBLIOGRAPHY

\section{APPENDICES}

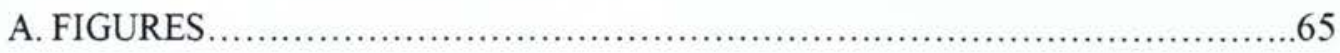

B. CATALOGUE OF THE VIEWS OF EGYPT ALBUM ......................................

C. LIST OF NEGATIVE NUMBERS

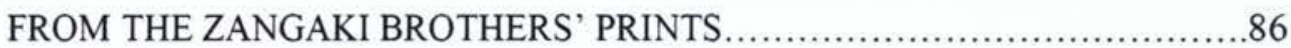

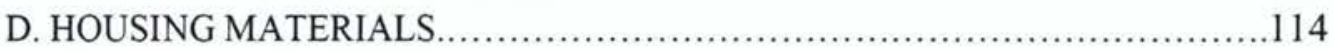




\section{$\underline{\text { ABBREVIATIONS }}$}

AGO

AUC

$\mathrm{BnF}$

Bottin

(journal)

Art Gallery of Ontario, Toronto, Ontario, Canada

Photographic and Cinema Collections in Rare Books and Special Collections Library, American University of Cairo, Cairo, Egypt

Département des 'Estampes et de la Photographie, Bibliothèque nationale de France, Paris, France

Annuaire et Almanach Du Commerce Et De L'Industrie De La Magistrature Et De L'Administration Ou Almanach Des 500,000 Adresses De Paris, Des Départements Et Des Pays Étrangers (Firmin Didot Et Bottin Reunis), later merged with AlmanachBottin

CCA

Centre Canadien d'Architecture, Montreal, Quebec, Canada

EgyptDirectory (journal)

GEH Annuaire Complet Du Commerce, De L'Industrie, De L'Administration Et De La Magistrature De L'Égypte Contenant Les Renseignements, Addresses Et Professions des 20 Principales Villes De L'Égypte

George Eastman House International Museum of Photography and Film, Rochester, U.S.A

Gri. Inst.

The Griffith Institute, Oxford, England

IndicatEgypt (journal) Indicateur Égyptien Administratif Et Commercial

Marta Braun Coll. Marta Braun's Private Collection, Toronto, Canada

UCL The University of Chicago Library, Chicago, U.S.A 


\section{LIST OF FIGURES}

Fig.1 Views of Egypt, ca.1880, red leather with gold painted border and embossed detailing on four corners containing 50 pages with 46 albumen prints, AGO: $2008 / 121$ 66

Fig.2 Zangaki brothers (Georgios Zangaki, ca.1845-ca. 1895, Constantinos Zangaki, ca.1845-1916), Edfou Bas-relief du temple de Horus, ca.1880, Albumen print, $21.5 \times 27.7 \mathrm{~cm}$., No.1037, in the Views of Egypt album, AGO: 2008/121.30 .....66

Fig.3 Zangaki brothers (Georgios Zangaki, ca.1845-ca.1895, Constantinos Zangaki, ca.1845-1916), Palmieres [sic] vis a vis[sic] du Kasr-el-Nil, ca.1880, Albumen print, 21.8 x $28 \mathrm{~cm}$., No.493, AGO: 2008/121.38.

Fig.4 Zangaki brothers (Georgios Zangaki ca.1845-ca.1895, Constantinos Zangaki, ca.1845-1916), Palmieres [sic] vis a vis [sic] du Kasr-el-Nil, detail of signature, ca. 1880 , Albumen print, 21.8 x 28 cm., No.493, AGO: 2008/121.38.

Fig.5 Zangaki brothers (Georgios Zangaki, ca.1845-ca. 1895, Constantinos Zangaki, ca.1845-1916), Palmieres [sic] vis a vis[sic] du Kasr-el-Nil, detail of negative number and title, ca.1880, Albumen print, 21.8 x $28 \mathrm{~cm}$., No.493, AGO: $2008 / 121.38$ 66

Fig.6 Pappa Peridis (active c.1890s-1905), Georgiladakis (active ca.1890-1910), Ramseon Luxor, detail of signature, ca.1890, Albumen print, 21.9 x $28.2 \mathrm{~cm}$, No.1030, AGO: 2008/121.14

Fig.7 Pappa Peridis (active c.1890s-1905), Georgiladakis (active ca.1890-1910), Grand temple Luxor, detail of negative number and title, ca.1890, Albumen print, 21.6 x $27.9 \mathrm{~cm}$, No.1026, AGO: 2008/121.16.

Fig.8 Pappa Peridis (active c.1890s-1905), Georgiladakis (active ca.1890-1910), [...]Karnac, detail of signature, ca.1890, Albumen print, $21.8 \times 27.9 \mathrm{~cm}$, No. 1060, AGO: 2008/121.21

Fig.9 Pappa Peridis (active c.1890s-1905), Georgiladakis (active ca.1890-1910), Grand temple Luxor, detail of signature, ca.1890, Albumen print, 21.6 x $27.9 \mathrm{~cm}$, No.1026, AGO: 2008/121.16

Fig.10 C. Zangaki (ca.1845-1916), Deux Femmes de Damietta, Damietta Women, ca.1900, No.1542, in Osman 1997 (137).

Fig.11 Zangaki brothers (Georgios Zangaki, ca.1845-ca.1895, Constantinos Zangaki, ca.1845-1916), [Two Middle Eastern Women], ca.1880, Albumen print, 21.7 x $28.2 \mathrm{~cm}$., No.11, AGO: 2008/121.2. 


\section{LIST OF FIGURES (continued)}

Fig.12 Zangaki brothers (Georgios Zangaki, ca.1845-ca.1895, Constantinos Zangaki, ca.1845-1916), Deux femmes arabes, ca.1880, Albumen print, No.737, UCL: 25961 .68

Fig.13 Zangaki brothers (Georgios Zangaki, ca.1845-ca.1895, Constantinos Zangaki, ca.1845-1916), Femmes arabes sur Baudets, ca.1880, Albumen print, No.576, GEH: 1983:1317:0003.

Fig.14 Zangaki brothers (Georgios Zangaki, ca.1845-ca.1895, Constantinos Zangaki, ca.1845-1916), Arabe prenant son caffe[sic], ca.1880, Albumen print, $21.8 \times 28.1$ cm., No.643, AGO: 2008/121.6.

Fig.15 Zangaki brothers (Georgios Zangaki, ca.1845-ca.1895, Constantinos Zangaki, ca.1845-1916), Epicerie[sic] arabe, ca.1880, Albumen print, $22.1 \times 28.2 \mathrm{~cm}$,

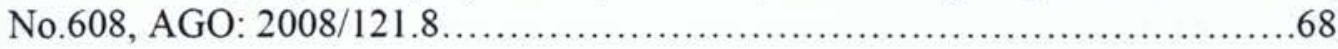

Fig.16 Zangaki brothers (Georgios Zangaki, ca.1845-ca.1895, Constantinos Zangaki, ca.1845-1916), Rue de com[erce a][sic] Port Said, ca.1880, Albumen print, No.34, BnF: 40492256, EO-487-BOITE FOL B

Fig.17 Zangaki brothers (Georgios Zangaki, ca.1845-ca.1895, Constantinos Zangaki, ca.1845-1916), Rue du comerce a[sic] Port-Said, ca.1880, Albumen print, No.458, GEH: 2001:1522:0007

Fig.18 Zangaki brothers (Georgios Zangaki, ca.1845-ca.1895, Constantinos Zangaki, ca.1845-1916), Rue du comerce a [sic] Port-Said, ca. 1880, Albumen print, $21.4 \mathrm{x}$ 27.7 cm., No. 456, GEH: 2001:1522:0007.

Fig.19 Zangaki brothers (Georgios Zangaki, ca.1845-ca.1895, Constantinos Zangaki, ca.1845-1916), Soldat Abyssin a [sic] Dogali, ca.1880, Albumen print, No. 521, AGO: 2008/121.40.

Fig.20 Zangaki brothers (Georgios Zangaki, ca.1845-ca.1895, Constantinos Zangaki, ca.1845-1916), [Bicharins...], ca.1880, Albumen print, No.517, BnF: 40492256, EO-487-BOITE FOL B

Fig.21 Zangaki brothers (Georgios Zangaki, ca.1845-ca.1895, Constantinos Zangaki, ca.1845-1916), Chadoufs de la haute[sic] Egypte[sic], ca.1880, 21.4 x $27.7 \mathrm{~cm}$., Albumen print, No.630, AGO: 2008/121.41.

Fig.22 Zangaki brothers (Georgios Zangaki, ca.1845-ca.1895, Constantinos Zangaki, ca.1845-1916), Saqqieh Egyptiene[sic], ca.1880, Albumen print, No.540, GEH: 2000:0814:0015. 


\section{LIST OF FIGURES (continued)}

Fig.23 Zangaki brothers (Georgios Zangaki, ca.1845-ca.1895, Constantinos Zangaki, ca.1845-1916), Plan du Canal, Maritime de Suez, ca.1870, Albumen print, Unnumbered, BnF: 40492256, EO-487-BOITE FOL B.....................70

Fig.24 Zangaki brothers (Georgios Zangaki, ca.1845-ca.1895, Constantinos Zangaki, ca.1845-1916), Bateaux arêtes[sic] a Port Said a[sic] cause de la Drague, ca.1870, Albumen print, No.9, BnF: 40492256, EO-487-BOITE FOL B

Fig.25 Zangaki brothers (Georgios Zangaki, ca.1845-ca.1895, Constantinos Zangaki, ca.1845-1916), Drague a'longue[sic] eculaine, ca.1870, Albumen print, No.461, BnF: 40492256, EO-487-BOITE FOL B.

Fig.26 Anon., Probably Zangaki brothers (Georgios Zangaki, ca.1845-ca.1895, Constantinos Zangaki, ca.1845-1916), [Aftermath of bombardment in Alexandria in 1882], after 1882, Albumen print, Unknown number, in Osman 1997 (70)

Fig.27 Anon.,Probably Zangaki brothers (Georgios Zangaki, ca.1845-ca.1895, Constantinos Zangaki, ca.1845-1916), [Aftermath of bombardment in Alexandria in 1882], after 1882, Albumen print, Unknown number, Osman 1997 (71)

Fig.28 Zangaki brothers (Georgios Zangaki, ca.1845-ca. 1895, Constantinos Zangaki, ca.1845-1916), Chameaux de mariage arabe, ca.1890, Albumen print, No.472 Marta Braun Coll

Fig.29 Zangaki brothers (Georgios Zangaki, ca.1845-ca.1895, Constantinos Zangaki, ca.1845-1916), Arivee[sic] du M[ahmel] Caire, ca. 1890, Albumen print, No.849, GEH: 1981:2126:0002.

Fig.30 Zangaki brothers (Georgios Zangaki, ca.1845-ca.1895, Constantinos Zangaki, ca.1845-1916), Vue des trois Pyramides, ca. 1880, Albumen print, No.376, GEH: 2001:1522:0016.

Fig.31 Zangaki brothers (Georgios Zangaki, ca.1845-ca. 1895, Constantinos Zangaki, ca.1845-1916), Assouan premier caracte[sic], ca.1880, Albumen print, $21.5 \mathrm{x}$ $27.5 \mathrm{~cm}$., No.1056, AGO: 2008/121.34. .72

Fig.32 Zangaki brothers (Georgios Zangaki, ca.1845-ca.1895, Constantinos Zangaki, ca.1845-1916), Le Muezzu Caire, ca.1890, Albumen print, No.78, Marta Braun Coll. 


\section{LIST OF FIGURES (continued)}

Fig.33 Zangaki brothers (Georgios Zangaki, ca.1845-ca.1895, Constantinos Zangaki, ca.1845-1916), Assouan Nile [...], detail of Olga, ca. 1890, Albumen print, No.792, Marta Braun Coll. .73

Fig.34 Zangaki brothers (Georgios Zangaki, ca.1845-ca.1895, Constantinos Zangaki, ca.1845-1916), Statue de Ramses III [...see] du Ramesseum Thebes[sic], ca. 1880, Albumen print, 21.4 x $28.2 \mathrm{~cm}$., No.926, AGO: 2008/ 121.9.

Fig.35 Zangaki brothers (Georgios Zangaki, ca.1845-ca.1895, Constantinos Zangaki, ca.1845-1916), Statue de Ramses a [sic] Louqsor[sic], ca.1880, Albumen print, No.646, GEH: 1978:1297:0020 .........................................73

Fig.36 Zangaki brothers (Georgios Zangaki, ca.1845-ca.1895, Constantinos Zangaki, ca.1845-1916), Le Sphynx et Pyramide, between 1865 and 1885, Albumen print, $22.7 \times 27.7 \mathrm{~cm}$., No.106, AGO: 2008/121.47.

Fig.37 Zangaki brothers (Georgios Zangaki, ca.1845-ca.1895, Constantinos Zangaki, ca.1845-1916), Le Sphynx Caire, between 1865 and 1885, Albumen print, No.206, GEH: 2001:1522:0015 .74

Fig.38 Zangaki brothers (Georgios Zangaki, ca.1845-ca.1895, Constantinos Zangaki, ca.1845-1916), [Le Sphinx], after 1885, Albumen print, Unnumbered, AUC: $19^{\text {th }}$ century photographs

Fig.39 Zangaki brothers (Georgios Zangaki, ca.1845-ca.1895, Constantinos Zangaki, ca.1845-1916), Sphynx decouvert[sic], after 1885, Albumen print, No.796, BnF: 40492256, EO-487-BOITE FOL B.

Fig.40 Zangaki brothers (Georgios Zangaki, ca.1845-ca.1895, Constantinos Zangaki, ca.1845-1916), Le Sphynx et Pyramide, detail of one of the Zangaki brothers, between 1865 and 1885, Albumen print, $22.7 \times 27.7 \mathrm{~cm}$., No.106, AGO: 2008/121.47 (See Fig.36 for the whole image)

Fig.41 Zangaki brothers (Georgios Zangaki, ca.1845-ca.1895, Constantinos Zangaki, ca.1845-1916), Sphynx et la grand Pyramide de Cheope, between 1865 and 1885, Albumen print, No.80, CCA: PH1986:0566.

Fig.42 Zangaki brothers (Georgios Zangaki, ca.1845-ca.1895, Constantinos Zangaki, ca.1845-1916), Pyramide de Cheops le Sphynx et le temple de Choffs, between 1865 and 1885, Albumen print, No.391, BnF: 40589991, IFN-7702173. . .75 


\section{LIST OF FIGURES (continued)}

Fig.43 Zangaki brothers (Georgios Zangaki, ca.1845-ca.1895, Constantinos Zangaki, ca.1845-1916), [Nubians and the crocodile], ca.1880, Albumen print, Unknown number, in Xanthakis 2005 (62), (Christian Adam Coll.) ........................75

Fig.44 Zangaki brothers (Georgios Zangaki, ca.1845-ca.1895, Constantinos Zangaki, ca.1845-1916), Le Sphynx et Pyramide, detail of the portable darkroom, between

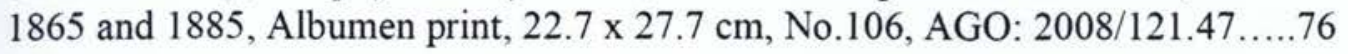

Fig.45 Zangaki brothers (Georgios Zangaki, ca.1845-ca.1895, Constantinos Zangaki, ca.1845-1916), [Lake Mariut], detail of the portable darkroom, ca.1880, Albumen print, Unknown number, Osman 1997 (4).

Fig.46 Zangaki brothers (Georgios Zangaki, ca.1845-ca.1895, Constantinos Zangaki, ca.1845-1916), Avenue des pyramides Cairo, detail of the portable darkroom, ca.1880, Albumen print, No.156, Nicholas Warner Coll.......................76

Fig.47 Zangaki brothers (Georgios Zangaki, ca.1845-ca.1895, Constantinos Zangaki, ca.1845-1916), Le Sphynx et Pyramide, detail of the inscription on the Sphinx, between 1865 and 1885, Albumen print, 22.7 x $27.7 \mathrm{~cm}$., No.106, AGO: 2008/121.47. 76

Fig.48 Zangaki brothers (Georgios Zangaki, ca.1845-ca.1895, Constantinos Zangaki, ca.1845-1916), Diner Arabe, ca.1880, Albumen print, No.598, UCL:381-95 .....77

Fig.49 Zangaki brothers (Georgios Zangaki, ca.1845-ca.1895, Constantinos Zangaki, ca.1845-1916), [Egypt, Arab Family], ca.1900, postcard publisher - C. Andreopoulos, Vegnios \& Zachos, postcard, approximately $15 \times 10.5 \mathrm{~cm}$, in Osman 1997 (134) .

Fig.50 Zangaki brothers (Georgios Zangaki, ca.1845-ca.1895, Constantinos Zangaki, ca.1845-1916), Femme arabe femme turque, ca.1880, Albumen print, No.803, BnF: 40492256, EO-487-BOITE FOL B

Fig.51 Zangaki brothers (Georgios Zangaki, ca.1845-ca.1895, Constantinos Zangaki, ca.1845-1916), [Two Middle Eastern Women], ca.1900, coloured photograph transferred either to a handkerchief or a silk place mat, in Jacobson 2007 (195).

Fig.52 Zangaki brothers (Georgios Zangaki, ca.1845-ca.1895, Constantinos Zangaki, ca.1845-1916), [Two Sudanese Women], ca.1880, Albumen print, No.582, in Osman 1997 (92). 


\section{LIST OF FIGURES (continued)}

Fig.53 Zangaki brothers (Georgios Zangaki, ca.1845-ca.1895, Constantinos Zangaki, ca.1845-1916), [Two Sudanese Women], ca.1900, postcard publisher - Edit, The Cairo Postcard Trust, coloured postcard, approximately $15 \times 10.5 \mathrm{~cm}$., Ebay (full website description can be found on footnote \#89). .78

Fig.54 Zangaki brothers (Georgios Zangaki, ca.1845-ca.1895, Constantinos Zangaki, ca.1845-1916), Fontaine de Moise el Suez, ca.1880, Albumen print, No.237, Marta Braun Coll.

Fig.55 Zangaki brothers (Georgios Zangaki, ca.1845-ca. 1895, Constantinos Zangaki, ca.1845-1916), Suez - Fontaine de Moise, ca.1900, postcard publisher - P. Peridis-Cairo, No.16, postcard, approximately $10.5 \times 15 \mathrm{~cm}$., Ebay (full website description can be found on footnote \#90) .78

Fig.56 Zangaki brothers (Georgios Zangaki, ca.1845-ca.1895, Constantinos Zangaki, ca.1845-1916), Porteur d'eau, ca.1880, Albumen print, No.573, BnF: 40492256, EO-487-BOITE FOL B. .79

Fig.57 Zangaki brothers (Georgios Zangaki, ca.1845-ca.1895, Constantinos Zangaki, ca.1845-1916), Porteur d'eau, ca.1900, postcard publisher - Ephtimios Frères Port-Said, postcard, approximately $15 \times 10.5 \mathrm{~cm}$., Ebay (full website description can be found on footnote \#91)

Fig.58 Zangaki brothers (Georgios Zangaki, ca.1845-ca.1895, Constantinos Zangaki, ca.1845-1916), [Egpytiennes], ca.1880, Albumen print, Unnumbered, BnF:40492256, EO-487-BOITE FOL B .................................... 79

Fig.59 Views of Egypt, detail of weakened binding, AGO: 2008/121 ...................79

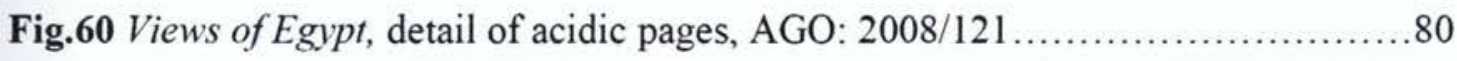

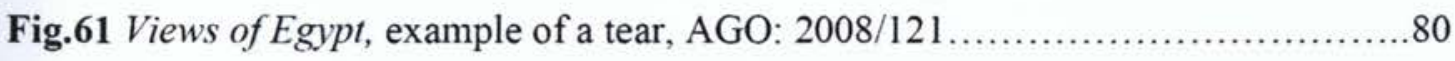

Fig.62 Views of Egypt, example of a crease, AGO: 2008/121 ........................ 80

Fig.63 Completed Views of Egypt prints in mylar sleeves with the Hollinger box, AGO: 2008/121. .80

Fig.64 Views of Egypt empty album shell stored in the Hollinger box, AGO: $2008 / 121$ 80 


\section{LIST OF APPENDICES}
A. Figures
B. Catalogue of the Views of Egypt Album
C. List of Negative Numbers from the Zangaki Brothers' Prints
D. Housing Materials 


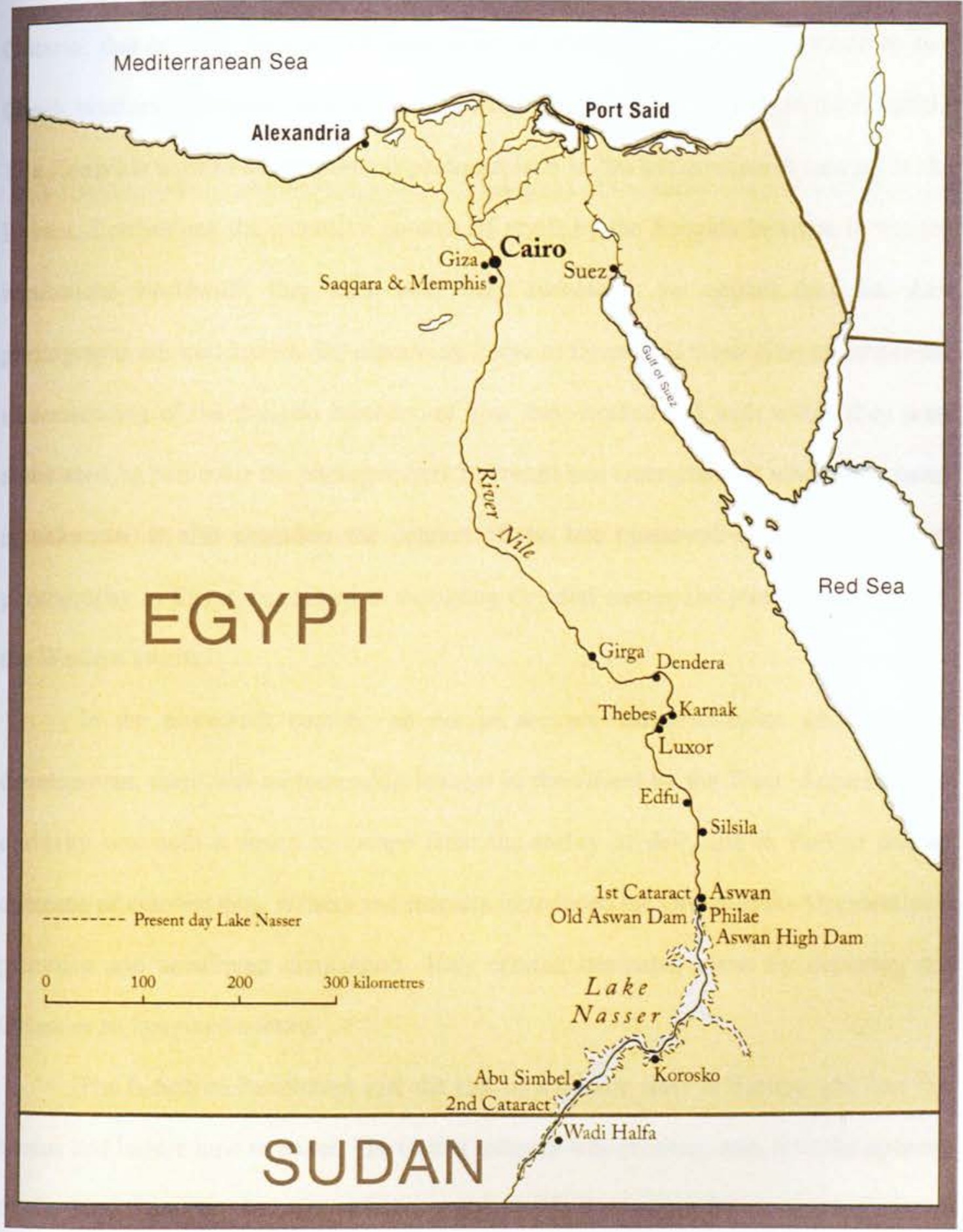




\section{INTRODUCTION}

This thesis focuses on Views of Egypt, an album housed in the Art Gallery of Ontario, that contains forty-six albumen prints of which twenty-seven are made by two Greek brothers: Georgios (ca.1845-ca.1895) and Constantinos (ca.1845-1916) Zangaki. ${ }^{1}$ The Zangakis worked as commercial photographers in the late nineteenth century in the Levant. Considering the extensive number of prints by the Zangaki brothers in various institutions worldwide, they must have been successful; yet neither they nor their photographs are well known. By examining Views of Egypt, this thesis aims to further our understanding of the Zangaki brothers, of how they worked and with whom they were associated, in particular the photographers P. Peridis and Georgiladakis whose first name is unknown. It also considers the context of the late nineteenth-century commercial photography in Egypt that aimed at supplying Oriental scenes and picturesque views to the Western tourist.

In the nineteenth century, an era of western industrialization and technical development, there was an increasing interest in the Orient by the West. Arguably, this curiosity was both a desire to escape from the reality of daily life in Europe and an outcome of colonization. Writers and painters introduced the Orient to the Occident as a primitive and uncultured civilization. They created fabricated views by depicting the Orient as an imagined culture.

The Industrial Revolution saw the rise of a middle class in Europe who had the means and leisure time to travel. The tourist industry was growing, and, with the opening of the Suez Canal in 1869, Egypt became a desirable destination for many travelers and

\footnotetext{
'Album not only includes the Zangaki brothers' photographs but also P. Peridis' (Greek, active ca.18901905 ) and Georgiladakis' (Greek, ca.1890-ca.1910), whose first name is unknown.
} 
tourists from Europe and America who were on their way to the Far East and India. Tourism also stimulated the photography market in Egypt, and photographers from different areas of the world came to establish photography businesses in Cairo and Port Said. Using established Western romantic notions of depicting the Orient, photographers in Egypt aimed at supplying Oriental scenes and picturesque views to the Western tourist. Thousands of albumen prints were produced in this period depicting a romantic and eroticized version of Egypt. Tourists were able to choose prints by different photographers and were offered an assortment of albums also by the photographers into which the photographs could be mounted. These albums would be sold to tourists as souvenirs of their travels in Egypt. The tourists could also take the prints home rolled up and buy their own album.

Albumen prints started to fade from the market with the invention of the Kodak camera by George Eastman in 1888 . There was no need for tourists to buy commercial photographs as they could take their own photographs and keep them as their souvenirs. In 1894 , the postal regulations were changed to allow the mailing of pictures on postcards. This created a new commercial field in the photography industry, and photographers were able to print their negatives on photographic paper or get their negatives printed on postcard stock in factories to sell to the tourists. The tourists were already familiar with the established Oriental scenes and picturesque views; this, therefore, led to a boom in interest and millions of postcards were printed.

In order to explore the Zangakis in context, the first section of this thesis, entitled "Photography in Egypt," will explore photography in Egypt from 1839 to the 1920s, including a brief history of Egypt in the nineteenth century, establishment of the Oriental 
genre, the history of tourism in the nineteenth century and, lastly, the photography processes used during this period. Following, "The Zangaki Brothers" will provide a biography of the Zangaki brothers, demonstrating that the available sources show that they are representative of their period, and, therefore, that further investigation into their biographies will add to our understanding of commercial photography in late nineteenthcentury Egypt.

There are components of the Zangakis' lives and practices that have not been researched thoroughly and that would add to our understanding of their period. My research will address these gaps, starting with an examination of the Views of Egypt album and cataloguing the photographs contained within (Appendix B). Following, in the "Construction of the Negative List" my focus will shift to the creation of the Zangakis' negative list, comparing Zangakis' prints from various institutions across the world. With their body of work partially collected, a close-examination of their photographs in the "Subjects" can tell us, in general, about the wide range of subjects one company would cover during this time, while revealing specific aspects about the Zangakis' practices, such as the props and the backgrounds they used repetitively and their inclusion of one of the brothers and their portable darkroom in their photographs. The section "Postcards," includes the postcards that I have found to illustrate the Zangakis' transition from albumen prints to postcards.

The act of culling and cataloguing the Zangakis' prints both sheds light on the history of this period and the brothers' biography and work. As it is important to keep these photographs in good condition for further study and exhibition, the Views of Egypt album and its photographs should be preserved. The last part of this thesis, "Preservation 
of Views of Egypt," examines the condition of the album and the photographs contained within. It includes the alternative housing solutions proposed, the decision made, and the steps ultimately undertaken in reconstituting the album for archival preservation. 


\section{LITERATURE SURVEY}

This literature survey is divided into three parts: first, books and exhibition catalogues that provide information (biographical and photography related) on the Zangaki brothers, Peridis and Georgiladakis; second, books that treat photography in Egypt in general; and, third, Egyptian guidebooks and directories. The earliest information on the Zangaki brothers is found in one book and two exhibitions catalogues on Middle East photography. Adam D. Weinberg mentions the Zangakis in his 1971 exhibition catalogue Majestic Inspirations, Incomparable Souvenirs: 19th Century Photographs of the Mediterranean and the Middle East, which includes an introduction to photography in the Middle East and short biographies of photographers who were included in the exhibition. Weinberg includes other historians' comments on the confusion about whether the brothers' family name is Langaki or Zangaki. Clearly, in 1971, historians were not sure about the origins of the Zangakis and did not know that the Zangakis were actually two brothers. Weinberg writes, "In any case, the mystery regarding his name and place of origin is indicative of how little we know about him."” About the photographs, Weinberg writes, "The works themselves exhibit a taste for simple composition with extreme care in the placement of figures." ${ }^{3}$ The Zangaki image entitled Le Sphynx et Pyramide was also the cover photograph of the catalogue.

Paul E. Chevedden's 1977 The Photographic Heritage of the Middle East: An Exhibition of Early Photographs of Egypt, Palestine, Syria, Turkey, Greece, \& Iran, 1849-1893 includes an overview of the beginning and development of the history of photography in general. Like Weinberg, he includes biographical information on Middle

\footnotetext{
${ }^{2}$ Adam Weinberg, Majestic Inspirations, Incomparable Souvenirs: 19th Century Photographs of the Mediterranean and the Middle East (Rose Art Museum, Brandeis University, 1977), 17.

${ }^{3}$ Ibid., 17.
} 
Eastern photographers, including the Zangaki brothers. Chevedden's words on the Zangakis are brief He too refers to the brothers as a single photographer, "G. Zangaki, a photographer probably of Greek origin, established a studio in Port Said at the entrance of the Suez Canal and produced a substantial volume of photographs throughout the 1870 s and the 1880 s. $^{.4}$

Focus East: Early Photography in the Near East (1839-1885) by Nissan Perez (1981) is a significant source for the history of photography in the Near East. Perez's publication is divided into two parts: first, the history of photography in the Near East including examples of photographs with standard subjects, and, second, biographies of photographers in alphabetical order who worked in the Near East. He gives each photographer's geographical origin, birth and death dates, active dates and medium. Perez is the first to understand that there are two photographers by the Zangaki surname and that they are brothers. He claims that one brother was the actual photographer and the second a technician. He includes the Zangakis as "C. \& G. Zangaki Brothers, Greek, dates unknown. Active 1870s. Collodion." Perez's work has both positive and negative aspects. Overall, his description is the most thorough. He writes that there are a very large number of Zangaki prints in almost every late travel album of the Near East but that there has been no biographical information on the Zangakis. In his description, he also points out the inscription Adelphoi Zangaki on their portable darkroom and that one of the Zangakis is included in their Le Sphynx et Pyramide. But he also states "Their work does not go beyond average commercial photography meant for the tourist and the occasional

\footnotetext{
${ }^{4}$ Paul Chevedden, The Photographic Heritage of the Middle East: An Exhibition of Early Photographs of Egypt, Palestine, Syria, Turkey, Greece, \& Iran, 1849-1893 (Malibu: Undena Publications, 1981), 28.

${ }^{5}$ Nissan Perez, Focus East: Early Photography in the Near East (1839-1885) (New York, N.Y.: Harry N. Abrams, and the Dimino Press Jerusalem, The Israeli Museum, Jerusalem, 1988), 233.
} 
visitor. It is difficult to find innovative vision or ground-breaking achievement in the mass of images they must have produced. ${ }^{16}$ However, by his own admission, he had not thoroughly researched the Zangaki brothers' images. ${ }^{7}$ Perez's publication is the first one to give brief biographical and photography related information for both Peridis and Georgiladakis. For both photographers, Perez includes the same label, "Greek, dates unknown. Active late 1870s. Collodion." ${ }^{\prime 8}$ As they were both Greeks and worked in the same period as the Zangakis, Perez seems to suggest that these four photographers were somehow associated with each other. Perez also writes that some of Peridis' photographs bear the name of Peridis $\&$ Co. He explains that Peridis was in a partnership with another Greek, Georgiladakis, and that their photography occasionally appears in albums of the late $1870 \mathrm{~s}$ and $1880 \mathrm{~s}$. This information is then repeated in the section on Georgiladakis.

Three more recent resources provide information on the Zangaki brothers, Peridis and Georgiladakis. Colin Osman's 1997 Egypt: Caught in Time is dedicated to photography in Egypt. This publication is significant because it presents many unpublished nineteenth-century and early twentieth-century photographs by neglected photographers. Unlike the other works, Osman describes the transition from the printing of 8 by 10 inch albumen prints to the production of picture postcards. Osman also includes biographical information on the Zangaki brothers, Peridis and Georgiladakis. He states that the Zangakis were either Cretan or Cypriot since their title, Adelphoi Zangaki, suggests they came either from Crete or Cyprus where the suffix "aki" is more common." Osman discovered the Zangakis' signatures on various mediums from

\footnotetext{
${ }^{6}$ Ibid., 233.

${ }^{7}$ Nissan Perez, e-mail message to author, April 27, 2009.

${ }^{8}$ Perez, Focus East, 203.

${ }^{9}$ Colin Osman, Egypt: Caught in Time (Reading, England. Garnet Publishing, 1997), 146.
} 
albumen prints to postcards. He refers to the Zangakis as being two brothers, and he writes, "One bowler-hatted brother appears in some pictures beside their darkroom van, on which their name appears in English and Arabic although their photographs are all captioned in French." ${ }^{10} \mathrm{He}$ also states, "Zangaki brothers were noted not only for their views but for depicting native life..." illustrate his sections: "The Middle East Entrepreneurs," "Life in the Countryside," "Life in the Towns" and "End of an Era." In his "Life in the Towns" section, he describes the Zangakis' use of backdrops as well as their photographic activities.

Osman includes Peridis as "Peredis, active 1890s (Greek?)"12 and states that Peridis was in partnership with Georgiladakis. He assumes that the Zangakis sold their negatives to Peridis because, as he claims, some of Peridis' images are identical to those of the Zangakis, "... for example Peridis no.5 is the same as a Zangaki no. $15 .{ }^{, 13} \mathrm{He}$ finds a connection between the similarities of Peridis' studio backgrounds and those used by the Zangakis, where Peridis may have been the assistant. Osman refers to Georgiladakis as "Georgiladakis, active 1880s - 90s (Greek?)"14 and adds that he was in partnership with Peridis and possibly an assistant to Hippolyte Arnoux (French, active ca.1860-1900) for an indefinite period of time. As Georgiladakis' work shows similarities with Arnoux's, Osman suggests that the two assistants joined forces when their principals moved on. ${ }^{15}$ Osman inspired me to look at postcards from Peridis and from other

\footnotetext{
${ }^{10}$ Ibid., 146.

${ }^{11}$ Ibid., 146.

${ }^{12}$ Ibid., 145.

${ }^{13}$ Ibid., 95 .

${ }^{14}$ Ibid., 143.

${ }^{15}$ Ibid., 145.
} 
photography firms to discover if any of these images were identical to those of the Zangakis.

Ken Jacobson's 2007 Odalisques \& Arabesques: Orientalist Photography 18391925 has been another key source. Eleven chapters explain the development of the Orientalist history of photography. The rest of the book includes a variety of high quality reproductions (a few Zangaki photographs) and biographies of the photographers. For each photographer's biography, Jacobson lists where he found the information whether from historians or travel guides or administrative and commerce directories.

Jacobson includes detailed biographical descriptions of the Zangakis and Peridis. $\mathrm{He}$ includes the Zangakis as "Zangaki Brothers: Georges Zangaki (active 1880s-1890s) and Constantin Zangaki (active 1880s-1915). ${ }^{16} \mathrm{He}$ also writes the names of the Zangakis' business addresses in Cairo and Port Said. He includes the Le Sphynx et Pyramide $^{17}$ and a close-up image of the portable darkroom included in the Zangakis' image. Jacobson includes Peridis as "P. Peridis (active c.1890s -1905)." ${ }^{18} \mathrm{He}$ also writes, "Considering the further complication that certain extant prints are signed by Zangaki and Arnoux, it seems certain that Greek ex-patriot photographers had a strong influence on the entire Port Said photography scene."19 $\mathrm{He}$ includes Georgiladakis under Peridis' biographical description: "Peridis' name was signed either with his last name or, on occasion, with the name of a sometime collaborator, Georgiladakis. ${ }^{20}$ In order to find

\footnotetext{
${ }^{16}$ Ken Jacobson, Odalisques \& Arabesques: Orientalist Photography 1839-1925, 277.

${ }^{17}$ The AGO has the identical print.

${ }_{18}^{18}$ Jacobson, Odalisques \& Arabesques, 260.

${ }^{19}$ Ibid., 260.

${ }^{20}$ Ibid., 260.
} 
more information on the Zangaki brothers, I wrote to Jacobson, and he referred me to Alkis X. Xanthakis. ${ }^{21}$

The ensuing phone conversation with Xanthakis gave me a different perspective on the Zangakis, Peridis and Georgiladakis. ${ }^{22}$ Xanthakis wrote the comprehensive History of Greek Photography 1839-1970, first edition in 1988 (in Greek and English) and the second in 2008 (in Greek). He has also written various articles on Greek photographers. Xanthakis provided me with valuable information about the Zangaki brothers, Peridis and Georgiladakis over the phone. He told me that he had obtained the information about the Zangakis from the grandson of Constantinos Zangaki (the younger of the Zangakis). Later, I contacted the Benati Museum in Athens for photocopies of Xanthakis' article on the Zangakis, and also for the chapter on them from the second edition of Xanthakis' History of Greek Photography 1839-1970. I had both of these publications translated, and they form the main source of the Zangakis' biography section. ${ }^{23}$

Deborah Bull and Donald Lorimer's 1979 Up the Nile: A Photographic Excursion, Egypt 1839-1898 has a very thorough introduction to the development of Egyptian photography and divides the country for these purposes into Cairo, Up the Nile, Thebes, Abu Simbel, etc. Each section describes the location and the photographs taken there. This increased my understanding of where Egypt-based photographers traveled to take photographs of Egypt.

\footnotetext{
${ }^{21}$ Ken Jacobson, e-mail message to author, April 28, 2009.

${ }^{22}$ Phone interview with Alkis X. Xanthakis, May 12, 2009.

${ }^{23}$ The unpublished translations were translated from Greek to English by Myrto Koumarianos. She informed me that the chapter on the Zangakis in Xanthakis' History of Greek Photography 1839-1970 is exactly the same as Xanthakis' article "Zangaki brothers: Two Creative Greek Photographers in Egypt." Koumarianos translated the three-paged article "Zangaki brothers: Two Creative Greek Photographers in Egypt."
} 
Louis Vaczek and Gail Buckland's 1981 Travelers in Ancient Lands: A Portrait of the Middle East 1839 - 1919 discusses photography in the Middle East, from the invention of photography to 1919 , with many images by various nineteenth-century photographers, most of which had never before been published. This publication was very helpful in understanding life in Egypt among villages, towns and cities, and along caravan routes.

A. Rammant-Peeters (ed.) and Palmen en Tempels's 1994 Fotografie in Egypte in de XIXe eeuw, La photographie en Egypte au XIXe siècle/19th-Century Photography in Egypt is mostly in French but also includes English sections. One English section, divided according to geographic locations in Egypt, including Alexandria to Memphis, Aswan, Suez and Edfu, contains a history of each and descriptions of photographs taken during different time periods and of the archeological changes that had taken place in those locations.

Finally, two travel guidebooks and three administrative and commerce directories from the late nineteenth and early twentieth centuries were helpful for understanding the period in Egypt and when and where photographers were active. The German publisher, Karl's Baedeker's Egypt: Handbooks for Travellers $(1878,1889,1898,1914)$ and the British publisher, John Murray and Son's A Handbook for Travellers in Lower and Upper Egypt $(1888,1891)$ were additional resources for this thesis in understanding the kind of information travelers were provided with. These guidebooks were divided by cities, including Cairo, Port Said, Alexandria, etc. They contained recommendations regarding what to see in Egypt, where to stay, where to eat, how to interact with the inhabitants, etc. The descriptions also indicated where to buy photographs, and which photographers had 
photography businesses. I tried to examine as many travel guidebooks as I could find in order to trace if the Zangakis were also included in them.

Ken Jacobson sourced the following administrative and commerce directories in his sections on the Zangakis and Peridis: Bottin ${ }^{24}$, IndicatEgypt and EgyptDirectory. I researched Bottin (1870, 1880, 1886-1889, 1890, 1895, 1900, 1910, 1920), IndicatEgypt (1897), and EgyptDirectory (1911, 1912, 1914-1922, 1925) to locate the Zangakis', Peridis' and Georgiladakis' names and the addresses where they worked. These findings provided me with information on when and where these photographers were active.

${ }^{24}$ Bottin, IndicatEgypt, and EgyptDirectory are abbreviations. The full names can be found in both the abbreviations section and the bibliography. 


\section{$\underline{\text { PHOTOGRAPHY IN EGYPT }(1839-1920 \text { s) }}$}

Egypt had been drawing Westerners long before the invention of photography.

Napoleon invaded Egypt in 1798 and wrested control from the Mamluks, who had ruled Egypt in the name of the Ottoman Empire since the thirteenth century. This was done for his Egyptian campaign (1798 -1801), to protect French trade interests and undermine Britain's access to India. Soon after, in 1801, Napoleon's authority was forced out by the joint forces of Britain and the Ottoman Empire. In the nineteenth century, both the British and the French expanded colonization to the countries or regions in Southwest Asia and parts of North Africa (including Egypt). These expansions resulted in Westerners desiring to better understand this region. Since the fourteenth century this area was called "Orient" to distinguish these regions from the "Occident." The terms Orient and Occident both derived from the Latin roots for the words "East" and "West."25

During his Egyptian campaign, Napoleon was precise in documenting his eastward expansion, bringing a team of astronomers, chemists, artists and engineers with him. Their findings were published in the massive Description de l'Égypte (1809-1813), which became the most complete documentation of Egypt to have appeared in the West. ${ }^{26}$ Travelers, archeologists, painters and writers became eager to see Egypt after reading the Description. As Nissan Perez writes, the Industrial Revolution in Europe caused an anxiety for the aristocracy and upper classes. He concludes, "The need to escape from the pressures of daily reality, to seek refuge in new and different vistas and interests was a major reason for the massive flow to the East that continued to grow from year to

\footnotetext{
${ }^{25}$ Billie Melman, "The Middle East / Arabia: "The Cradle of Islam," The Cambridge Companion to Travel Writing, Eds. Peter Hulme and Tim Youngs, (Cambridge University Press, 2002), 105.

${ }^{26}$ Deborah Bull and Donald Lorimer, Up the Nile: A Photographic Excursion, Egypt 1839-1898 (New

York: C. N. Potter, 1979), vii.
} 
year." ${ }^{27}$. Ideas about the orient influenced almost all creative areas in Europe, mainly in literature and painting. Painters, Eugène Delacroix, Jean-Léon Gérôme and Jean Auguste Dominique Ingres depicted the Islamic culture. In their paintings, they stressed idleness and visual spectacle. Victor Hugo's poems Les Orientales (1829), Gerard de Nérval's Voyage en Orient (1884) and Gustave Flaubert's Salammbô (1862) portray the people and the landscape as exotic and romantic to fulfill these writers' fantasies. Jacobson includes Gustave Flaubert's letter to Dr. Jules Cloquet written in 1850 after his arrival in Egypt explaining his feelings: “...It is like being hurled while asleep into the midst of a Beethoven symphony, with the brasses rumbling, and the flutes sighing away... But the first days, by God, it is such a bewildering chaos of colours that your poor imagination is dazzled as though by continuous fireworks as you go about staring at minarets thick with white storks, as tired slaves of sycamore branches against walls, with camel bells ringing in your ears and great herds of black goats and the peddlars. You brush against all the costumes of the Orient..., the Copt in his black turban, the Persian in his fur pelisse, the desert Bedouin with this coffee-coloured face walking gravely along enveloped in his white robes." 28

In 1978, Edward Said redefined our understanding of this kind of romanticism in his book Orientalism, in which he examined the Western activity during this period and saw it as a part of the Western plan of dominating the East. A new discipline, "Orientalism" was born, and Said describes the term "....as a Western style for dominating, restructuring, and having authority over the Orient. ${ }^{, 29}$ Said and other postcolonialist theorists named the nineteenth-century writers and painters "Orientalists," and

\footnotetext{
${ }^{27}$ Perez, Focus East, 32.

${ }^{28}$ Jacobson, Odalisques \& Arabesques, 20.

${ }^{29}$ Edward Said, Orientalism (London: Routledge and Kegan Paul, 1978), 3.
} 
claimed that these writers and painters considered themselves superior to the people who were living in the Orient. They argued that the Orientalist writers and painters constructed fantasies of the Orient instead of trying to understand the culture.

As Perez states, "Orientalism became the study of 'inferior' cultures and races." 30 Perez uses the example of the French poet Gérard de Nerval's portrayal of the Orient. He writes: "Nerval recognized the Orient as a place of dreams and illusions and sensed in Cairo the presence of rich female sexuality. Regarding his liaison with Zaynab, the slave he claimed to have bought in Egypt and the heroine of his Voyage en Orient, Nerval expressed the need to "unite with this guileless young girl who is of this sacred soil, which is our first homeland," and to bathe himself "in the vivifying springs of humanity, from which poetry and the faith of our fathers flowed forth. ${ }^{.31}$ Here, we see Nerval's idealizing of the culture by his portrayal of Eastern women as simultaneously innocent and sensual. Although post-colonial criticism has critiqued, complicated and built upon Said's work, his theories continue to be influential when examining literature and art that romanticized the East.

The Industrial Revolution in Europe resulted in social and economic changes that transformed society from a rural to an urbanized one. With the rising middle class's increased ability to travel, the modern concept of tourism came into being. After the mid $1850 \mathrm{~s}$, as traveling to the Orient grew more popular, organized groups and packaged tours became available. Thomas Cook was one of the first to open up organized tours to the Orient to the members of the middle class. Cook was a British founder of the travel agency that is now Thomas Cook Group and is referred to as the father of tourism. His

\footnotetext{
${ }^{30}$ Perez, Focus East, 37.

${ }^{31}$ Perez, Focus East, 35.
} 
cheap overseas tours made it possible for men and women, to go abroad easily. He introduced pre-paid inclusive tours, hotel coupons, travellers cheques, the 'round the world' trip and the first travel newspaper. ${ }^{32}$ With these organized tours, the middle class started to travel to the same exotic locales to experience the exotic dreams of the Orient they had been reading about.

Since the Middle Ages, Egypt had been an important historical and archaeological location. The opening of the Suez Canal made it a major tourist destination. Opened in November of 1869, the Suez Canal is an artificial sea-level waterway in Egypt, connecting the Mediterranean Sea and the Red Sea that allows water transportation between Europe and Asia without navigating around Africa. Following its construction, Alexandria and Port Said in Egypt on the shores of Mediterranean Sea became two major trade centers. Ships carrying tourists who were in the organized packaged tours and were traveling to India and the Far East from Europe docked in Port Said for coaling. This process took a day or two, and western tourists avoided the delay by taking a train from Port Said to Cairo and rejoining the ship in Suez.

In François Arago's 1839 presentation of the Daguerreotype process, he connected the new technology to the Orient, announcing that photography would be the best medium to reproduce hieroglyphics covering exteriors of Thebes, Memphis, and Karnak in Egypt. Arago's claim was fulfilled first with daguerreotypes and later with calotypes of Egyptian antiquities, and these became the first photographic documents of Egyptian sites.

\footnotetext{
${ }^{32}$ Jill Hamilton, Thomas Cook: The Holiday Maker (Stroud, Gloucestershire: Sutton Pub., 2005), vi.
} 
Yet photographers in Egypt were not only interested in documentation; Entrepreneurs capitalized on the new technology and the rising tourist industry and began to sell their photographs to tourists. The route through the Suez Canal created a new stopover in Egypt: Port Said. Photographers from different areas of the world came to Port Said to establish photography businesses whose main customers were Western tourists.

Dean MacCannell defines a tourist attraction "...as an empirical relationship between a tourist, a sight and a marker." ${ }^{33}$ Egypt's attraction was both as a part of the Orient (or exotic locale) and being the location of the pyramids and the Sphinx. MacCannell's definition of a tourist attraction includes a marker - a physical piece of information about a sight. The sight was Egypt and its marker was a souvenir, in this case, souvenir photographs depicting the Oriental themes in literature and painting that portrayed Egypt as an imagined culture. Photographs, with their documentary approach and wide accessibility, became the means of marketing the Orient to the West. They were the visual symbols of the exotic dream and the evidence of the tourist's existence in this exotic locale.

The photographs that the tourists purchased in this period were affordable albumen prints made from wet collodion negatives. Baedeker's guidebook, Egypt. Handbook for Travellers (1878), provides specific shops for tourist photographs, including: Kauffmann in the Muski, Monferrato (formerly Robertson), adjoining Shepheard's hotel and Ebener, opposite to Hotel d'Orient. ${ }^{34}$ These prints were not only sold in photography studios, but also in hotels and booksellers' shops. In fact, the shops

\footnotetext{
${ }^{33}$ Dean MacCannell, The Tourist: A New Theory of the Leisure Class, (New York: Schocken Books, 1976), 41.

${ }^{34}$ Karl Baedeker, Egypt. Handbook for Travellers (Leipzig, London: Dulau, K.Baedeker, 1878), 232.
} 
around the Ezbekieh Square in the European quarter, where the famous Shepheard's Hotel was situated, were usually filled with tourists purchasing albumen prints. In these locations, tourists were able to choose albumen prints from different photographers, and these photographs were later mounted in albums. The tourists bought these albums as souvenirs for their travels in Egypt, "souvenir" referring to a relic of a trip. They also brought home unmounted prints and would sometimes personalize the albums and photographs with notes.

Photographers in Port Said and Cairo not only had portrait studios in those cities, they also traveled along the Nile to Upper Egypt to photograph Egyptian antiquities and the countryside. Some had floating darkrooms on the Nile, or portable darkrooms to carry and develop their negatives. They portrayed Egypt in studio portraits, mostly of women, including Oriental props (water pipe, water carrier, tambourine); constructed daily-life street scenes (showing the Oriental professions of the street); picturesque views (palm trees and the Nile River); and Egyptian monuments and sites. The photographs of Egyptian sites included inhabitants and represented them in their native costumes. As we know from different photographers' signatures on the same print, associations among these Egypt-based photographers were common. They exchanged and sold each others' negatives because they were able to make more money selling the most popular images to tourists.

\section{PROCESS}

The prints the tourists bought were albumen, made from both full-plate ( 8 by 10 inches, 22 by 28 centimeters) wet plate glass negatives and gelatin dry plate negatives. 
Frederick Scott Archer published a detailed description of wet collodion process on glass in the March 1851 issue of The Chemist. Archer's formula for making wet collodion was a preparation using potassium iodide and adding it to a diluted solution of collodion. The glass plate was then coated with this collodion and put into a solution of silver nitrate for a layer of silver iodide to appear just under the surface of the collodion. The sensitized plate was then exposed while still wet, developed with pyrogallic acid, and then fixed in sodium thiosulfate. ${ }^{35}$ The wet plate allowed the photographers to have "sharper negatives and more detailed positive prints than those created through the paper negative processes, ${ }^{36}$ and they were able to print multiple prints on salted and albumen paper.

Photographers used the wet collodion process from 1851 to ca. $1885 .{ }^{37}$ There is not much information found on when Egypt-based photographers stopped using collodion and shifted to gelatin dry plate negatives. For the wet place process, albumen paper (often gold-toned) was the most common print until about 1895. Albumen was prepared in France and Germany near the paper mills to produce the highest quality of paper. For example, some of the Zangakis' prints have the watermark, BFK Rives No 74. This is inscribed at the bottom of the prints, mostly on the edge. BFK Rives was a French brand of albumenized paper for photographic printing.

The equipment for wet collodion process was bulky and the plates were fragile. After the exposure, the wet negative plate had to be developed right away. In the desert heat of Egypt the collodion dried rapidly. Thus, many photographers had to build

\footnotetext{
${ }^{35}$ 6. Mark Osterman and France Scully Osterman, "Collodion: Wet-Plate Negatives, Ambrotypes, and Tintypes" in Coming into Focus: A Step-By-Step Guide to Alternative Photographic Printing Processes, ed. John Barnier (San Francisco: Chronicle Books, 2000), 63.

${ }^{36}$ Maria Fernanda Valverde, Photographic Negatives: Nature and Evolution of Processes (Rochester: International Museum of Photography and Film, George Eastman House, 2005), 9.

${ }^{37}$ Ibid., 9 .
} 
portable darkrooms to develop their negatives. Francis Frith (1822-1898), a well-known British photographer who worked in the Near East in the 1850s, wrote of his troubles working among ether fumes in an airless tent in 130 degrees Fahrenheit heat. He was amazed by his own success; "Now in a smothering little tent, with my collodion fizzing boiling up all over the glass the instant that it touched -and, again, pushing my way backwards, upon my hands and knees, into a damp, slimy rock tomb to manipulate - it is truly marvelous that the results should be presentable at all." 38

Another issue posed by the cumbersome darkroom used by the photographers was the question of transport from location to another. The darkroom had to be transported along the Nile on a Dahabeah, ${ }^{39}$ a passenger boat commonly used on the river. Murray includes an explanation of the role of the Dahabeah in his section Railways - Modes of Travelling, "The great highway of Egypt, especially above Cairo, is the Nile, and sailing or floating along it in a Dahabeeyeh is still, railways and steamboats notwithstanding, the pleasantest way of seeing the country., ${ }^{40}$

The replacement of collodion with a gelatin binder was a significant innovation. The first dry plates were invented in 1871 by Richard Leach Maddox (1816-1902) and were in general use from ca.1878 to ca. $1925{ }^{41}$ Valverde writes, "Gelatin, a protein product, is manufactured by the partial hydrolysis of collagen found in connective tissues and skin of animals. This protein provides a viscous medium to suspend the lightsensitive silver salts and form an emulsion with them. ${ }^{42}$ The photographic emulsion already contained the light-sensitive silver salts suspended in the gelatin dry plate

\footnotetext{
${ }^{38}$ Cited in Bull, Up the Nile, xii.

${ }^{39}$ Dahabeah is also spelled as Dahabeeyah, Dahabiah, Dahabiya, and Dahabiyah.

${ }^{40} \mathrm{John}$ Murray, A Handbook for Travellers in Lower and Upper Egypt (London: John Murray, 1888), 5.

${ }^{41}$ Valverde, Photographic Negatives, 14.

${ }^{42}$ Ibid., 14.
} 
negative, thus there was no need to have separate solutions of these salts before the exposure. Gelatin dry plate negatives were printed on albumen, which was slowly replaced by pre-sensitized collodion and gelatin printing out papers. With the gelatin binder, photographers were able to have ready-to-use light-sensitive plates and the exposure times were less than a second. They were able to freeze motion in their photographs.

Valverde explains the benefits of the light-sensitive plates, saying, "Their long shelf life and the possibility of developing the image much later owing to the hygroscopic characteristics (drawing moisture from air) of gelatin freed photographers from the need to carry a portable darkroom into the field. ${ }^{, 43}$ Egypt-based photographers were producing large quantities of demanding collodion glass plate negatives, thus they assumedly moved to use gelatin dry plate negatives as soon dry plates became available in Egypt. Baedeker's Egypt. Handbook for Travellers (1914) provides specific recommendations on where to purchase dry plates in Cairo under the Photographic Materials section, including: "Heyman \& Co., agent for the Eastman Kodak Co.; films supplied and plates developed." ${ }^{44}$

Wet collodion negatives were replaced by dry plates, and later albumen prints started to disappear from the market. After the invention of Kodak camera by George Eastman in 1888 , there was no need for tourists to buy commercial photographs since amateur photographers could take their own photographs and kept them as their souvenirs. In 1894, the postal regulations were changed to allow the mailing of pictures on postcards. Picture postcards were mostly printed from existing late nineteenth-century

\footnotetext{
${ }^{43}$ Ibid., 14.

${ }^{44}$ Baedeker, Egypt. Handbook for Travellers (Leipzig, London: Dulau, K.Baedeker, 1914), 28.
} 
wet collodion or gelatin dry plate negatives. The tourists were already familiar with existing romantic notions of the Orient and immediately adapted to purchasing picture postcards of them. This led to a boom in interest and millions of postcards were printed. Tourists bought postcards "To get a rise out of the people at home - to shock them, to temp them, one-up them. To deceive some people, to make them envious. To confirm their stereotype of the Other, to emphasize their journey..."45 Postcards were (and still are) inexpensive, accessible and they require little effort on the part of the tourist.

\section{Adding Text to Negatives}

Photographers working in the nineteenth-century in Egypt added text to their negatives for printing. They inscribed their names, negative numbers and titles of the location/subject. This most likely made it easier for the owner of the bookseller or the hotel store to locate a specific photographer's print from thousands of albumen prints to sell. Each photographer had an individual numbering system for his negatives. This was important for him to keep track of his negatives and made it easy to locate a negative of a print that a tourist ordered. The title of the location/subject was inscribed to identify the name of the location or the ethnicity of the figure in the image.

Mark Osterman, the Process Historian of the George Eastman House, described how photographers added text to their negatives for subsequent printing. Osterman explained that he knew of photographers adding text in three ways. The first way is simply scratching the name or location with a sharp metal point on the binder layer of the negative, which would require writing backwards. This side would face the paper during

\footnotetext{
${ }^{45}$ Alan Beukers, Introduction to Exotic Postcards: The Lure of Distant Lands by Paul Theroux (New York: Thames \& Hudson, 2007), 12.
} 
printing and it would print as black. The second way would be to write backwards on the binder layer of the negative with India ink. This would print as white on the paper. The third technique was to use a letterpress and type to print the words on a very thin slip of translucent onion skin paper (very fine cotton paper). This then would be applied to the binder side of the negative with gum solution and would print as white. In this case, there will be a trace of the onion skin paper on the print. ${ }^{46}$

\section{Postcard Production}

Following the postal regulations change in 1894 that allowed the mailing of pictures on postcards, there were two major types of picture postcards: real photo (RPPC) and printed. The first major type, RPPCs were true photographs printed by a photographer from a negative chemically on the photographic paper with postcard backs. The second type, printed view cards (only photographs, not artist drawings), were made in two ways: "Local merchants or photographers could bring or send photos to a printing firm or jobber (firms that took orders but sent the printing or to manufacturers, many of whom were abroad) and order printed postcards made from them. The other, more common, approach was for a company to send an agent to take photographs of the local sight. While in a town the employee would take orders from local merchants or make contacts to send samples. The photographs would be brought back to the company, selected, made into plates or screens, printed, and then sold to the local store owners. ${ }^{47}$

With the arrival of $\mathrm{PZ}$ (Photoglob Zurich) print, a type of colour printing, the product became more polished. The process was called Photochromy and was developed

\footnotetext{
${ }^{46}$ Mark Osterman, email message to author, July 6, 2009.

${ }^{47}$ Robert Bogdan and Todd Weseloh, Real Photo Postcard Guide: The People's Photography (Syracuse, N.Y.: Syracuse University Press, 2006), 7.
} 
in Zurich by Orell, Füssli and Co. in $1887 .^{48}$ "This process is not colour photography, but rather the use of collotype photolithography with a solution of asphaltum of ether, and involves as many as sixteen printings of different colours." ${ }^{49}$ Photographs seen in the late nineteenth-century as albumen prints printed by Egypt-based photographers were later printed as postcards by printing firms such as Vegnios \& Zachos, Ephtimios Frères, Edit - The Cairo Postcard Trust and Comptoir Philatélique d'Égypte, Alexandrie. ${ }^{50}$

\footnotetext{
${ }^{48}$ Osman, Egypt, 145.

${ }^{49}$ Ibid., 145 .

${ }^{50}$ Research has turned up little information on Vegnios \& Zachos, Edit - The Cairo Postcard Trust, and Comptoir Philatélique d'Égypte, Alexandrie. Ephtimios Frères worked as photographers, booksellers and publishers of postcards in the $1900 \mathrm{~s}$.
} 


\section{THE ZANGAKI BROTHERS}

The Zangakis were among the commercial photographers who worked in the late nineteenth century in Egypt. There are at least one thousand five hundred prints in collections today that I know of which shows that they were prolific and successful photographers. It seems like every photography collection worldwide contains at least one Zangaki print, however, neither their biographies nor their photography is well known. The little we do know shows us that their careers touched on all the aspects of the history of the industry presented above.

Apart from the sources in the literature survey above, the information I obtained from Xanthakis made a difference in what I knew about the Zangakis. According to Xanthakis, the two brothers, Georgios (George) and Constantinos (Constantine), were born around 1845 on the island Milos. As Xanthakis explains: "Their family had kinship ties to Heraklion of Crete, where Constantinos went for a while. ${ }^{51} \mathrm{He}$ later married Eleni Koutsoudaki, from Adamanta of Milos, a tall and beautiful woman who was called "goddess" by many because she looked like the statue of Aphrodite found in Milos (commonly known as the Venus de Milo)." ${ }^{52}$

The older brother, Georgios Zangaki, went to Egypt first around 1865 and settled in Port Said. Soon his younger brother, Constantinos, followed him. The beginning of the Zangakis' career in photography coincides with the rise of tourism in Egypt. In fact, their earliest photographs show that they were involved with photographing the opening of Suez Canal in 1869. As mentioned above, the inauguration of the Suez Canal was a key moment in the history of tourism, opening Europe to Far East and India. The Zangakis

\footnotetext{
${ }^{51}$ Xanthakis has not included how long Constantinos Zangaki went to Crete for.

${ }^{52}$ Xanthakis, "Zangaki Brothers: Two Creative Greek Photographers in Egypt," (Unpublished translation by Myrto Koumarianos, Athens, Fotografos vol.141, 2005), 62.
} 
were among the photographers who recognized the importance of the Suez Canal and capitalized on this key moment in history.

Around 1870 , the Zangakis opened a photography studio in Port Said. ${ }^{53}$ Typically, they sold photographs to Western tourists. They drew on the recognized genre of Orientalist scenes from earlier literature and paintings, and with their contemporaries, constructed Orientalist scenes in an effort to cater to tourists' perceptions of the region. They constructed outdoor scenes depicting the Oriental life style. Their extensive output during this time shows us that they were able to deliver exactly what the Western tourist wanted.

The Zangakis' traveled up the Nile to photograph the monuments at Luxor, Abu Simbel, Karnak, and other areas in Egypt. They recognized that the Western tourists were looking for photographs of Egyptian antiquities to use as souvenirs to map their route in Egypt. The Zangakis were also familiar with romantic notions of portraying the Nile and the palm trees. They continued to be industrious photographers, delivering hundreds of photographs from these locations. They also photographed the indigenous people living in these areas, as it seems that they were familiar with the Western tourists' perception that the indigenous peoples from the countryside were more exotic than the Egyptian peasants from the more populated areas. Around 1880, the Zangakis also traveled to Palestine and the Holy Land. ${ }^{54}$ As Greek Orthodox themselves, the Zangakis recognized this as an opportunity to see the Holy Land and also to sell their photographs to the tourists.

\footnotetext{
${ }^{53}$ Xanthakis did not include when exactly the Zangakis opened their studio in Port Said.

${ }^{54}$ Xanthakis, "Zangaki Brothers," 63.
} 
When Cairo became a popular city for European tourists, becoming another stop over for tourists traveling to Far East and India, the Zangakis saw this as a business opportunity. Around 1895, they opened a photography studio in Cairo. In his article, Xanthakis includes a document, most likely the back of a Zangaki carte-de-visite or cabinet card, ${ }^{55}$ that shows the Zangakis' name, Zangaki Frères Photographes, and both of their studios, "Port -Said \& Caire Egypte." The Zangakis' process was typical of their period. They were using wet collodion negatives on albumen paper since all their prints in the collections today are albumen prints. Their prints' sizes are typically 8 by 10 inches ( 22 by $28 \mathrm{~cm}$.), which shows that they used full-plate wet collodion negatives. After the invention of the gelatin dry plates, the Zangakis switched to using them as everyone else did.

Soon after the opening of their studio in Cairo, Georgios died, and Constantinos closed the studio in Port Said. After Georgios' death, according to Xanthakis, Constantinos sold a large part of the Zangakis' negatives to Peridis and Arnoux. Photographers sold and exchanged negatives; this may be the reason we encounter Peridis' and Arnoux's signatures on some of the Zangakis' negatives.

Constantinos Zangaki was aware of the change in the photography industry, and he became active in the business, producing Zangaki postcards until his death in 1916. EgyptDirectory shows that Constantinos had an active studio in two different locations in Cairo from the 1910s until 1916. The EgyptDirectory of 1912, 1914, and 1915 included "Constantinos (C.) Zangaki" as having a studio in Cairo at C; Ch.el-Mahdi. However, the EgyptDirectory of 1916 and 1917 included as "Zangaki C. Co.," at Ch. El-Guinenah. Thus, the title Constantinos Zangaki, illustrating an individual, was changed to

${ }^{55}$ Xanthakis "Zangaki Brothers," 62. Xanthakis did not include what kind of a document this was. 
Constantinos Cooperation, illustrating a firm. Some of the postcards that Constantinos produced were later copied by Comptoir Philatélique d'Égypte, Alexandrie and by $G$. Lékégian (ca.1887-1925, an Armenian photographer) in Cairo. ${ }^{56}$ The Zangakis' images also can be found as postcards today under different photography firms' names. Their postcards are representative of the change during this period and are fine examples of the transition from albumen prints to postcards.

Constantinos Zangaki died in 1916 in Cairo and was buried in a family tomb, possibly in the Greek Orthodox cemetery in Cairo. With his death, the studio was closed, and the negatives were scattered or destroyed. As Xanthakis explains, the Zangakis remained unknown in Greece because they did not take part in exhibitions, like many of their Greek colleagues who lived in Egypt.

As mentioned above, the Zangakis had both an indoor and an outdoor studio. Jacobson pointed out three administrative and commerce directories in his Odalisques \& Arabesques for the Zangakis, the Bottin annual ${ }^{57}$, EgyptDirectory and IndicatEgypt. I had a chance to research the Zangakis in these directories. The Bottin annual includes the Zangakis' studio in 1886 in the Port Said section: "Photographie orientale: Zangaki Frères, vues du canal et d'Orient" (Oriental photography: Zangaki Brothers, Views of the Canal and the Orient). This is interesting since in the Bottin 1880, Arnoux is described under Port Said as "Arnoux (H.) photographies d'Egypte et de tout l'Orient" (Arnoux (H.) photographs of Egypt and the entire Orient). When the Zangakis were included in the section, Arnoux's title changed to "Photographie: Arnoux (H.)" (Photograph: Arnoux

\footnotetext{
${ }^{56}$ Xanthakis, "Zangaki Brothers," 64.

${ }^{57}$ Bottin, EgvptDirectory and IndicatEgypt are abbreviations. The full names can be found in both the abbreviations section and the bibliography. These abbreviations are listed with a single year.
} 
(H.). This change suggests that Arnoux was no longer known as the photographer of the Orient; the Zangaki brothers became known as the photographers of the Orient. The Bottin of 1890, 1895 and 1900 describe the studio as: "Photographie orientale: Zangaki Frères" (Oriental Photography: The Zangaki Brothers). As Xanthakis states, Georgios died around 1895. However, the IndicatEgypt of 1897 still included both the Zangakis in Cairo as "Zangaki Frères; Photographie Orientale," and they were located at rue de la division. This reason could be that the directory did not update their studio's information. Xanthakis states that Constantinos closed the studio in Port Said; however, the Bottin still included the Zangakis as "Zangaki Frères" in 1900 as a business in Port Said. The reason could be because they were known as the Zangaki Frères, Constantinos did not want to change the name of their studio. 


\section{VIEWS OF EGYPT}

The AGO's Views of Egypt album contains forty-six albumen prints depicting views of Egypt from around 1865 to the $1890 \mathrm{~s}$. The prints are approximately $21.5 \mathrm{~cm}$ by $28 \mathrm{~cm}$. The subjects of the photographs are hieroglyphics, studio portraits, the Nile, the Pyramids, life in Egypt, and Egyptian antiquities. Twenty-seven of these are by the Zangakis, ten by Peridis, three by Peridis \& Georgiladakis, and six prints are without a signature. A single signed Zangaki print accompanied the album when it was acquired in 2008. It is mounted on a separate album page.

This album is red leather-bound. There is a gold painted border around the edges and embossed detailing on the four corners of both the front and back covers of the album (Fig.1). It is a thin album that measures $1.7 \mathrm{~cm} \times 29.1 \times 39.1 \mathrm{~cm}$. The album has fifty pages in total. It has an empty leaf in the front and in the back. Between these two leaves, there are forty-six pages (twenty-three attached leaves). The photographs are slotted into the four corner "pockets" on each floppy leaf of the album (Fig.2). Each leaf (two attached leaves) can hold two photographs; one in the front and one in the back, and the four corners of each photo are hidden inside these two leaves. Out of the forty-six albumen prints, forty-one of them were slotted into the leaves and five were stacked loosely at the back of the album. The album has only one inscription on the inside of the front cover indicating " 45 photos" in pencil, possibly written by the buyer of the album since the markings seem recent in their clarity and meticulousness. We can assume that the photographs were purchased in Egypt, but the traveler may have purchased the album shell either in Egypt or upon arrival home. 
As Maia Sutnik, the Photography Curator of the AGO informed me, the additional mounted Zangaki print Le Sphynx et Pyramide was borrowed in 1986 from an anonymous owner who gave permission to frame it, and exhibited at the AGO along with prints by other photographers, including Antonio Beato and Samuel Bourne. The exhibition considered the divergent approaches to exploration photography, "...that is the idea of the optical purity of the photographic image (topographical evidence) verses the desire of the picturesque (aesthetic formulation)." ${ }^{" 58}$ This was a complementary installation to "Linneaus Tripe: Photographer of British India 1864-1870," an AGO exhibition from November 1, 1986 to January 11, 1987. Views of Egypt was borrowed from the same anonymous owner and included in the AGO exhibition, "Architectural Journeys: A Panoramic View” from November 14, 1996 to March 2, 1997. Before the exhibition, several photographs had come loose from their corner placements. There was no visual or documented record of the original order or subsequent sequencing. The owner had put them back in the album before the exhibition. No information is known about when exactly the owner put the stacked five prints in the back of the album, rather than bending and putting them back into their corners. Later, the album and the additional Zangaki print were sold to a dealer, and the AGO acquired them in $2008 .^{59}$

There were several preservation problems with the prints. They were not glued to the album leaves; instead, they were slotted into each leaf of the album. After consultations with Sutnik and Katharine Whitman (the Conservator, Photographs at the AGO), we decided that we would remove the prints from the album. ${ }^{60}$ As a result, I was

\footnotetext{
${ }^{58}$ Maia Sutnik, e-mail message to author, July 21, 2009.

${ }^{59}$ Maia Sutnik, e-mail message to author, April 20, 2009.

${ }^{60}$ Further discussion on this can be found in the section entitled "Preservation of Views of Egypt."
} 
able to examine the full titles and the signatures that were hidden under the corners. In addition, I was able to see the versos of the prints.

Following the removal of the prints from the Views of Egypt album, sub-numbers of $2008 / 121$ (album's accession number) were created from 2008/121.1 to $2008 / 121.47$ to the forty-seven prints including the additional Le Sphynx et Pyramide. The AGO accession numbers follow the placement of the photographs in the album when the AGO received it. Subsequently, I created a catalogue of the photographs on a Microsoft Excel spreadsheet and it is sorted according to the order of the AGO accession numbers (Appendix B). This excel sheet can subsequently be modified and imported into the AGO collections management system. ${ }^{61}$

${ }^{61}$ The Catalogue will be imported upon completion of the AGO's current transition into a TMS database. 


\section{CONSTRUCTION OF THE NEGATIVE LIST}

While cataloguing the prints from the Views of Egypt album, I was simultaneously creating a list of the numbers that the Zangaki brothers assigned to their negatives. The list was expanded to include negative numbers found on prints from different institutions $^{62}$ and created on a Microsoft Excel spreadsheet (Appendix C). The negative list consists of eight hundred seventy four prints found in collections. ${ }^{63}$

Putting the Zangakis' negative numbers in ascending order allowed me to trace the locations the Zangakis visited, and this illustrated their route through Egypt. While creating the list, I was able to observe identical prints of the Zangakis from various institutions thus revealing their most popular images. Some of these duplicates had different negative numbers that illustrated the Zangakis' print group production. This refers to changing the negative number for different printings of the same negative. In general, this negative list acted as a tool to further understand the content and the subjects of the Zangakis' images.

In this list, the smallest negative number is "l" and the biggest negative number is "1672." From the list, we can verify that the Zangakis were based in Port Said because the first approximately thirty negative numbers are on prints of Port Said. Following, they photographed Cairo until the negative numbers 500s. The list follows as, Memphis, Nubia, Thebes, Karnak, Assouan Abydos, Denderah, Thebes, Luxor, Karnak, Jerusalem, Philae, Jerusalem, Bethlehem and Jaffa. Before negative number "1162," the list is

\footnotetext{
${ }^{62}$ Original images were examined from "Département des Estampes et de la photographie in la Bibliothèque nationale de France," "Photographic and Cinema Collections in Rare Books and Special Collections Library at the American University in Cairo" and the collection of Marta Braun. The rest of the images were found online from institutions and these prints' catalogue information is taken from their existing catalogue information.

${ }^{63}$ Aside from the list, according to Andrea Hackman, there are roughly two hundred prints at the Harvard Fine Arts Library and one hundred fifty prints at the New York Public Library.
} 
relatively complete, but, after " 1162 ," there is a considerable number of negative numbers missing up to "1672." There are no prints found for negative numbers in the 1200 s or 1300 s, only two prints in the 1400 s, three prints in the 1500 s and nine prints in the 1600 s.

The creation of this list includes several duplicates of prints from various institutions. These duplicates bear the same negative numbers. However, there are duplicate prints of the same image but with different negative numbers. There are three examples found in the Views of Egypt album that have duplicate prints at the GEH and the Griffith Institute. First, the negative number "920" in Thebes Memorium de Ramses...[III] (AGO) and the negative number "646" for the same image (Gr. Inst.); second, the negative number "953" in Vue generalle[sic] de Louqur[sic] (AGO) and the negative number " 685 " for the same image (Gr. Institute); third, the negative number "1020" in Edfou Pylone du temple de Horus (AGO) and the negative number "637" for the same image (GEH). This is interesting because, as mentioned above, the Zangakis inscribed negative numbers on their negatives; yet there is no evidence of an earlier existing negative number on the prints. Osterman clarified this problem, suggesting that the ink can be made to come off. ${ }^{, 64}$ The Zangakis erased an earlier existing negative number on the negative according to print group production, which was usual practice at the time. Possibly, they printed a group in year "x," and, in year "y," they changed the negative number and printed another group.

The Zangakis' negative numbers revealed the chronology of the locations they visited. For example, the Zangakis photographed Edfou in negative number 1020s to 1030s (N. 1020 Edfou Pylone du temple de Horus, N. 1024 Edfou Interieur[sic] du

\footnotetext{
${ }^{64}$ Mark Osterman, email message to author, July 6, 2009.
} 
temple, N. 1025 Edfou Vue generale[sic] du temple, N. 1032 Edfou Interieur[sic]). The Zangakis photographed Dendera in negative number 900s (N. 900 Denderah Temple Athor (AGO), N. 901 Denderah Entrée d'antinaos (AGO) and N. 902 Denderah Colonnade (UCL) and N. 906 Offrande de Ramsis Denderah (UCL).

Also mentioned above, after the death of Georgios Zangaki, Constantinos Zangaki started publishing postcards. Osman included a postcard ${ }^{65}$ by Constantinos Zangaki in his Egypt: Caught in Time that is included in postcard production section of this thesis (Fig.10). ${ }^{66}$ This postcard in fact was made from an albumen print from the 1880s. It has an inscription on the bottom left "C. Zangaki Photographe" and "1542" on the bottom right. This number might be the same number as the albumen print or a new number that Constantinos invented for his postcards.

\section{NEGATIVE INSCRIPTIONS}

The Zangakis were consistent in adding their name, negative number and title of location or subject on their negatives. They handwrote their name on their prints as Zangaki on the bottom left (Fig. 3, 4) and wrote the negative number followed by the title of the location or subject in French on the bottom right (Fig.5). The French captions were used because French was the lingua franca language of Egypt during the nineteenth century, the second language after Arabic. These texts appear as white. Osterman examined the Zangakis' prints at the GEH and concluded that the words were written backwards on the binder layer with India ink. The binder layer would face the paper

\footnotetext{
${ }^{65}$ Osman, Egypt, 137.

${ }^{66}$ Further information on this can be found on page 61 .
} 
while printing and would print out as white ${ }^{67} \mathrm{He}$ also explained "the script on the prints shows a very slow hand with lots of thought." ${ }^{38}$

After close-examination of Peridis' and Georgiladakis' prints in Views of Egypt, it seems clear that their approach to adding text to their negatives was very similar to the Zangakis'. Their handwriting is also similar to those of the Zangakis. This may have come about as a result of their working together and adopting each others' technique, or perhaps simply because they had access to each others' work. Both Peridis' and Georgiladakis' prints include their handwritten names as Peridis and Georgiladakis on the bottom left (Fig.6) and the negative number followed by the title of the location or subject in English on the bottom right (Fig.7). English was commonly used in Egypt after the British occupation in 1882 . This difference between the languages of the titles is a method that I have found to distinguish both Peridis' and Georgiladakis' prints from those of the Zangakis. As Perez, Osman and Jacobson state, Peridis and Georgiladakis were partners for a brief period. This is understood by their adjoined signatures Peridis $e$ Georgiladakis. Peridis e Georgiladakis [...] Karnac (AGO) illustrates both Peridis' and Georgiladakis' signatures. However, Georgiladakis' signature was written afterwards, resulting in its bolder appearance than that of Peridis (Fig.8). After Peridis' and Georgiladakis' partnership ended ${ }^{69}$, they might have divided their negatives and erased each other's names from the negatives. Despite these efforts, the evidence of erasure of their former partners' names is still visible. Some of the examples that Georgiladakis' signature was erased include Peridis e, Grand temple Luxor (AGO) (Fig.9) and Peridis, Ramses at Karnac (AGO).

\footnotetext{
${ }^{67}$ Mark Osterman, e-mail message to author, July 6, 2009.

${ }^{68}$ Ibid.

${ }^{69}$ Research has turned up no information on when Peridis' and Georgiladakis' partnership ended.
} 


\section{$\underline{\text { SUBJECTS }}$}

Putting the negative numbers in consecutive order allows us to see, for the first time, the brothers' career as a whole. Besides revealing more about their practice, they illustrate the wide range of subjects one company might cover and increase our understanding of photographic practices during this time. Furthermore, we can learn more about the Zangakis' lives and methods when we look at idiosyncratic practices or subjects that help identify their photographs more easily. The Zangakis sometimes included one of the brothers and their portable darkroom in their images and also used a distinct set of props and backgrounds. They created theatrical scenes constructing 'real' Oriental scenes for the viewer. Their subjects can be divided into five sections: Oriental portraiture in their indoor studio and 'Real life' Oriental scenes in their outdoor studio; Life on the streets and in the countryside; Coverage of current events; Landscapes and cityscapes; and Documentation of Egyptian monuments and sites. This section will also examine the appearance of one of the Zangakis and their portable darkroom.

\section{Oriental portraiture in their indoor studio and}

\section{'Real life' Oriental scenes in their outdoor studio}

As Osman and Jacobson point out, the Zangakis might have been the assistants to Arnoux or worked with Arnoux when they arrived in Port Said. There are many similarities between the indoor studio photographs that are known to have been taken by Arnoux and the Zangakis. By looking at prints from both Arnoux and Zangaki, we can see that these photographs have three identical props: the same palm tree backdrop, the identical water pipe and decorative stool. 
In their indoor studio, the Zangakis used painted backdrops (palm trees and the Pyramid and the Sphinx) to emphasize that their subjects are supposedly portrayed in their natural setting. They also used props that drew on clichés previously established in the genre of Orientalist painting, such as water pipes, water carriers, and tambourines. They often portrayed the women with the black burgu (face veil). This made the women "attractive subjects" ${ }^{70}$ for the standard tourists. The veil has been the most dominant article of clothing in Western images of the Middle Eastern woman. Especially for Western men, veiling represented sensuality. The Zangakis' [Two Middle Eastern Women] (AGO) is a perfect example of this use of the veil (Fig.11). The image is of two standing women, one with a white and one with a black burgu. The two women in the image are photographed against a white background, another example, Deux femmes arabes (UCL), is also of two women (both wearing black burgus) (Fig.12). In both photographs, one of the women has put her hand onto the other woman's shoulder evoking a sensual nature. These two women look directly at the viewer confronting him with their gaze. This would make them seem sexually available given the tradition of images of women who are objects of the male gaze and therefore look shyly away or down. The Zangakis' photographs are examples of the portrayal of the Eastern women to the Western tourist.

Photographers in this period also posed figures outdoors creating 'real' Oriental scenes. Chicken baskets, water carriers and donkeys were used as props to portray the exotic. Yet, while other photographers I have examined posed their figures in several regular backgrounds, the Zangakis used a specific outdoor studio. It included the

\footnotetext{
${ }^{70}$ Sarah Graham-Brown, Images of Women: The Portrayal of Women in Photography of the Middle East 1860-1950 (London: Quartet Books Limited, 1988), 43.
} 
following three components: a mashrabiya ${ }^{71}$ (carved wood latticed window) on the left, a brick arch on the right and a twisted tree on the top right. Graham-Brown writes "the point of mashribiyya windows was to allow women to see out without being seen from the street." ${ }^{72}$ However, the Zangakis misrepresented the mashrabiya by including men in the window (Femmes arabes sur Baudets (GEH), Fig.13). The mashrabiya was seen as an exotic entity to the Western culture, and the Zangakis took advantage of this. They used this studio background for almost all of their outdoor photographs. When searching for a picture postcard by the Zangakis (even if it says it was published by another photography firm or photographer), one can distinguish the Zangakis' images by the mashrabiya background.

Arabe prenant son caffe[sic] (AGO) is an example of a constructed daily scene using the mashrabiya background and various props (Fig.14). It is an example of a frozen moment, including two men, one standing while holding a traditional coffee carrier and the other one sitting on a chicken basket while holding a traditional coffee mug. This photograph, with many other examples, gives the impression of a theatre scene, with the background and props carefully chosen to interact with the actors of the play.

\section{Life On the Streets and In the Countryside}

After the documentation of Egyptian monuments in the 1850s, photographers turned to the daily life on the streets and in the countryside. These included bazaars, small markets, street scenes and courts of the Mosques. These locations were part of the fantasy of Orientalism. The Zangakis' Epicerie[sic] arabe (AGO) seems to have been a

\footnotetext{
${ }^{71}$ Also is spelled is mashribiyya.

${ }^{72}$ Ibid., 44.
} 
popular choice for tourists, as there are many duplicates of this image (Fig.15). It depicts a local grocery store, its proprietor and two other men in a well-balanced composition. Photographs of street views of Cairo and Port Said show the boom in tourism, including tourists in their western-style suits and store signs in English and French. Rue de co[merce a][sic] Port Said (BNF) (Fig.16), Rue du comerce a[sic] Port-Said (GEH) (Fig.17) and Rue du comerce a[sic] Port Said (GEH) (Fig.18) are three examples of the main street in Port Said. These three photographs show western-style suits with Turkish fez (a red felt hat in the shape of a truncated cone) and bowler hats on people. All signs are in English and French, illustrating Thomas Cook's office, a Clock maker, the Eastern Telegraph Office, Hotel Metropole, Egyptian Cigarettes A. Vafiadis, Deutsche Berhalle, etc.

In addition to scenes from towns, the Egyptian countryside was also a popular subject. Western tourists were interested in different ethnic groups inhabiting Egypt; they were considered primitive and more exotic than the Egyptian locals from populated major cities. According to Osman, "the black Nubians and light-coloured Sudanese were generally believed to be superior to the Egyptian peasant, and were considered to be more exotic, therefore of greater photographic interest." ${ }^{23}$ Thus, photographers used them in their photographs extensively to sell to tourists. The Zangakis traveled to $\mathrm{Nubia}^{74}$ to photograph the Nubians. Bull writes, "Western travelers found the Nubians exotic. They were dark skinned and described in contemporary accounts as extremely handsome and proud in their demeanor. The Nubians' dress was scant and, no doubt, tantalizing to the

\footnotetext{
${ }^{73}$ Osman, Egypt, 92.

${ }^{74}$ Nubia began at the First Cataract of the Nile, continued past the Second and extended beyond the Sixth Cataract to Khartoum.
} 
heavily garbed Western tourists." 75 The Zangakis, being aware of the tourist's desire, photographed the Nubians extensively.

Soldat Abyssin a[sic] Dogali (AGO) illustrates a man seated on a camel and brandishing his spear (Fig.19). The Bicharins [...] (BnF) illustrates Nubian men posing on the rocks (Fig.20). The man sitting on the middle right is most likely the same man seated on the camel from the Soldat Abyssin a[sic] Dogali (AGO). These two photographs are a part of a series that can be found in other collections. Nubee[sic] Bicharins $(\mathrm{GEH})$ and Nubie, Richurins en voyage $(\mathrm{BnF})$ include the same men, and, in all three, the central man is still brandishing his spear. By examining the Zangakis' photographs, I have observed that by using the same scene or figures, they took many pictures of the same subjects. Although, the tourists considered the Nubians as primitive, the Zangakis seem to respect them. They position the Nubians sitting on their camels brandishing their spears so that the camera looks up to them. In this way, the Zangakis succeed in conveying the Nubians' courage and pride.

Shadouf and sakkia, irrigation tools to draw water from the Nile, were of interest to the Western tourist because they seemed primitive. The Zangakis photographed these two tools together with men and boys who worked them. These images portray a straightforward view of the location. Chadoufs de la haute[sic] Egypte[sic] (AGO) (Fig.21), Chadoufs de la haute[sic] Egypte [sic](BnF) and Saqqieh Egyptiene[sic] (GEH) (Fig.22) are some of the examples.

${ }^{75}$ Bull, Up the Nile, 112. 


\section{Coverage of Current Events}

Photographers during this period captured current events, such as the opening of the Suez Canal in 1869. An albumen print of the Zangakis, Plan du Canal, Maritime de Suez (Plan of the Canal, the Suez Maritime Canal) (BnF) (Fig.23), includes the plan of the canal, twenty-four small albumen prints cut in octagonal shapes and the Zangakis' name on the bottom left corner of the plan inscribed as Zangaki Frères Port-Said. This is a well-presented and well-composed print illustrating the Zangakis' precise work ethic. As a significant document of the Suez Canal, it shows portraits of pashas including their names and portraits of women and views of the Canal including its location names. Bateaux arêtes a Port Said acause de la Drague [sic] $(\mathrm{BnF})$ illustrates sightseeing ships in order in front of Port Said (Fig.24). The Zangakis also documented coaling stations of ships (Drague a'longue[sic] eculaine (BnF), Fig.25).

Alongside their contemporaries, the Zangakis photographed the aftermath of the British Mediterranean Fleet bombardment that took place in Alexandria on 11-13 July 1882. Pan-Islamic nationalist activity against Westernization peaked on $11 \mathrm{July}$ and during this peak, there was a fleet of fifteen Royal Navy in Alexandria. A riot broke out and the pan-Islamic nationalists killed the Europeans. Following, there was a conflict between Britain and Egypt over the fortifications. As a result, Britain bombarded Alexandria and defeated the Egyptian troops and Egypt became a British protectorate until 1922. Xanthakis includes a detail from one of their images of Pharos of Alexandria showing one of the Zangakis taken standing in the ruins of the destroyed fort. ${ }^{76}$ Osman also includes four possible prints ${ }^{77}$ by the Zangakis of the aftermath of the bombardment

\footnotetext{
${ }^{76}$ Xanthakis, "Zangaki Brothers," 64.

${ }^{77}$ Osman, Egypt, 69-71.
} 
in Alexandria. He states that they are not signed but the captions are exactly in the style of the Zangakis. These photographs provide important documentation of the bombardment (Fig.26 and Fig.27).

The Zangakis photographed processions such as weddings and the return of the Mahmal (pilgrimage caravan) from Mecca. Chameaux de mariage arabe (Marta Braun Coll.) is a very good typical example of a wedding at the time, and a popular image amongst the tourists since there are several duplicates of it in collections today (Fig.28). The subject, part of an Arab wedding, corresponds with the procession of the camelleaders and camels decorated with drums. The Zangakis captured the return of the Mahmal (pilgrimage caravan) in their Arivee[sic] du M[ahmel] Caire (GEH) (Fig.29), which is an example of this ceremonial event witnessed by huge crowds. This image shows the procession in the city of the Mahmal on its return journey from Mecca. It includes covered litters, carrying women pilgrims.

\section{Landscapes and Cityscapes}

Photographs of landscapes and cityscapes, demonstrating the exotic locale, were major tourist choices. The landscapes were mostly views of the Nile River, palm trees, Dahabeahs, steamboats, and also of reflections of palms trees and pyramids. The Zangakis' Vue des trois Pyramides (GEH) includes the three pyramids of Giza (Cheops, Chephren and Micerinus) reflected in the smooth surface of the Nile (Fig.30). A shadouf can also be seen on the left of the image. In other images of the Zangakis, they portrayed the water sellers and women with their water carriers in the water. After the invention of the gelatin dry plates, as an alternative of capturing the Nile's smooth surface, the 
Zangakis photographed the Nile in movement. Assouan premier caracte[sic] (AGO) is an image of large waves (Fig.31). In the middle of this image, there seems to be a man with his arms in the air falling into the water. This image is a key example of the use of gelatin dry plate negatives, which resulted in faster exposures. With the dry plate, the Zangakis captured ships sailing on the water, men bathing in the flow of the Nile and details of the waves on the water.

The Zangakis captured cityscapes from a higher distance overlooking Islamic architecture, houses on the shore of the Suez Canal and entire cities. This was a way to exemplify the Islamic architecture since it was considered exotic to the tourist. Le Muezzu Caire (Marta Braun coll.) is an image including one of the minarets (generally tall spires with onion-shaped crowns of the mosque) and of the muezzin (the person at the mosque who leads the call and the daily prayers) (Fig.32). The minaret is placed vertically in the middle of the image while it presents a view of the city in the background. This image has an appealing feature, the crescent on the top-left of the minaret, which shows the indication of the retouching during printing.

\section{Documentation of Egyptian Antiquities}

In several of the Zangakis' photographs, there is a Dahabeah shown gliding on the water. The name Olga is inscribed at the bottom of the boat, and there is a Greek flag waving in the wind (Fig.33). This may be the Dahabeah that the Zangaki brothers used to travel up the Nile. They photographed Egyptian hieroglyphics, columns, temples, tombs, statues, the Sphinx, and the Pyramids. These locations were already familiar to most

people since Maxime du Camp (French, 1822 - 1894), Gustave Le Gray (French, 1820- 
1884), Francis Frith (British, 1822 - 1898), and other photographers had photographed them using calotype process on salted and albumen paper in the 1850s. Late nineteenthcentury photographers photographed Egyptian monuments and sites for different reasons. The generation of 1850 s provided the first photographs of Egypt. Late nineteenth-century photographers' photographs were for tourists to take home as souvenirs of their travels in Egypt.

Early and late nineteenth-century photographs of Egyptian monuments often included not only the site but also the photographers' dragomen. Murray explains the definition of a dragoman in his guidebook, A Handbook for Travellers in Lower and Upper Egypt (1888), "The dragoman, literally an interpreter, will take all trouble off his hands, and for a fix sum defray all the expenses of travelling, food, lodging, servants, \&e. ${ }^{\text {78 }}$ Early photographers used dragomen to give a sense of proportion, emphasizing the size of the monument. However, late nineteenth-century photographers also included their dragomen to portray the Oriental inhabitants in their traditional costumes. Their photographs included not only their dragomen but also their camels and donkeys to make the photograph Oriental and, therefore, saleable to the tourist. Some Zangaki photographs of this genre are Statue de Ramses III [...see] du Ramesseum Thebes (AGO) (Fig.34), Philae Vue d'ensemble de colonnade temple d'Isis (AGO) and Statue de Ramses a [sic] Louqsor[sic] (GEH) (Fig.35).

Photographers in the late-nineteenth century attempted to capture the Sphinx from a range of angles and at different times/periods, often including their dragomen, camels and donkeys, and also soldiers and tourists. The Zangakis' photographs of the Sphinx are

\footnotetext{
${ }^{78}$ Murray, A Handbook for Travellers in Lower and Upper Egypt (1888), 5.
} 
particularly important because one can see follow the progressive clearing of sand around the Sphinx. There were three known excavations of the Sphinx in the nineteenth-century. In 1853 and 1858, the sand was partially cleared by Auguste Mariette (the founder of the Egyptian Antiquities Service) but despite Mariette's work, the sands soon invaded the breast area of the monument again. In 1885, Gaston Maspero (director of the Antiquities Service) attempted to clean the Sphinx's forelegs. Le Sphynx et Pyramide (AGO) (Fig.36) and the Le Sphynx Caire (GEH) (Fig.37) can be dated before 1885 since the breast area is covered with sand and camels are sitting on a sandbank that covers the Sphinx's forelegs. [Le Sphinx] (AUC) (Fig.38) and Sphynx decouvert[sic] (BnF) (Fig.39) can be dated after 1885 that shows Maspero's excavation of the forelegs.

\section{Appearance of One of the Zangakis and Their Portable Darkroom}

Perez, Osman, Xanthakis and Jacobson point out that, in several of the Zangakis' images, their portable darkroom and one of the Zangakis are visible. This was useful for these historians in trying to figure out that there were two brothers. Xanthakis speculates that the bearded man in their photographs is Constantinos. From the inscription on their carriage these historians assumed that the Zangakis were possibly Greek until Xanthakis' locating the grandson of Constantinos. Future research remains to be done to bring together several Zangaki photographs that include one of the brothers and their portable darkroom.

There is a possible reason why the Zangakis included one of them in their photographs. This was a way to exemplify that they were the makers of their images. The man with the bowler hat around the Sphinx is one of the brothers as is the figure standing 
on the Sphinx - Le Sphinx et Pyramide (AGO) (Fig.36 and Fig.40), sitting on the Sphinx Sphynx et la grand Pyramide de Cheope (CCA) (Fig.41) and standing at a distance from the Sphinx - Pyramide de Cheops le Sphynx et le temple de Choffs (BnF) (Fig.42). Two other images also include one of the brothers; Rue Kormar a[sic] Suez (Marta Braun coll.) and Avenue des pyramides Cairo (Nicholas Warner coll.).

Xanthakis included [Nubians and the crocodile], ${ }^{79}$ which is an image of a stuffed crocodile surrounded by inhabitants on the shores of the Nile (Fig.43). They are pretending to fight the crocodile as the Zangakis had told them to hold still due to the slow exposure of wet collodion process. This image also possibly includes one of the brothers kneeling next to the crocodile. Though this man does not have a bowler hat, he has a western-style suit and light coloured hat. His pose shows the right side of his face. Nubie Prise d'un Crocodil (BnF) and La Chasse du crocodil au bord du Nil (BnF) are also of the same scene but exclude the brothers. [On the Edge of the Jordan] (GEH) includes a person with western-style suit on the left next to the tree, and Le bain a [sic] la Mer Morte (GEH) also includes this same person standing on the shores of the Dead Sea. This person might, once more, be one of the brothers.

The Zangakis also included their horse-drawn portable darkroom in their images to illustrate where these images were developed and printed. There are three photographs found of the Zangakis that included their carriage. Each photograph illustrates a different side of their carriage: back, left and right side. The name of the firm of the Zangaki brothers is written in Greek, English, French and possibly in Arabic on the three sides of their carriage. All four languages are included for logical reasons, Greek as the Zangakis'

\footnotetext{
${ }^{79}$ Xanthakis, "Zangaki Brothers," 62 . Xanthakis wrote that this photograph was located in the Christian Adam Collection.
} 
first language (indicating that they were Greek), Arabic as the predominant language in Egypt and, lastly, French and English as commonly spoken languages among the colonizers and tourists. The names on their carriage functioned not only as an advertisement for their business but also presented their name to the viewer to who bought the print. In the Le Sphynx et Pyramide (AGO), the back of their carriage can be identified by the Greek inscription "Adelphoi Zangaki Fotografoi," meaning "Zangaki Brothers, Photographers" (Fig.44). Osman included a detail of the Zangakis' [Lake Mariut], ${ }^{80}$ which shows the right side of the darkroom inscribed as "Zangaki Bros, Photographers" in English (Fig.45). Their exhausted horse is visible in this one as well. In the Zangakis' image, Avenue des pyramides Cairo (Nicholas Warner Coll.), the left side of the carriage has a French inscription [Zangaki Frères] Photographes (Fig.46). The middle part of this inscription seem like it is in Arabic, but I was not able to distinguish the letters.

Le Sphynx et Pyramide (AGO) carries an additional element. After closeexamination of this image, I found an inscription in black, Zangaki, on the Sphinx, between the shadow of the Sphinx and the kneeling inhabitant, an ideal place from which to create an illusion that it is written on the Sphinx (Fig.47). Because of its black colour, it could only be done by scratching it (while writing backwards) on the binder layer of the negative. The Zangakis also wrote their name as Constantin or Zangaki with a white paint directly on the statue/pyramid like graffiti. These two methods were also done as a protective measure, so that if the negative was lost or destroyed, any existing print of the Sphinx would still have name Zangaki inscribed on it.

\footnotetext{
${ }^{80}$ Osman, Egypt, 4.
} 


\section{$\underline{\text { POSTCARDS }}$}

As advancements in photography led to the development of the postcard, many existing negatives were reprinted as postcards. The Zangakis were successful photographers not only because their albumen prints circulated widely but also because many of their images were printed and sold as postcards. One cannot know if they were printed with the photographers' permission or from an original or a copy negative without their knowledge. I have found five examples to demonstrate that the Zangakis' albumen prints were printed as postcards by other photography firms. I have also found one postcard that has Constantinos Zangaki's name on it, verifying Xanthakis' assumption that Constantinos was involved in postcard production. The Zangakis' postcards, whether they were printed by photography firms or by Constantinos, are representative of the transition from albumen prints to postcards from the 1870 s into the 1920s.

Diner Arabe (UCL) by the Zangakis is a horizontal photograph of a constructed family scene having dinner around a chicken basket sitting on the ground (Fig.48). This image is a striking one, catching the act of eating. The positions of the figures form a circle and the woman in the middle becomes the center point. Osman includes a coloured postcard $^{81}$ [Egypt, Arab Family] (Fig.49). This image has the same composition and figures as Diner Arabe, although it is vertical and there is a slight difference in the figures' positions. Most likely, the Zangakis took several frames of the family. It was a characteristic of the Zangakis' photography practice to take more than one picture of the same scene, and explains the small changes in the image. This postcard is a Zangaki image. Osman writes that this postcard may have been published by C. Andreopoulos,

\footnotetext{
${ }^{81}$ Osman, Egypt, 134.
} 
who was the shop owner of Vegnios \& Zachos in Cairo. The stamp is inscribed with the words Poste Française, Port Said.

Femme arabe femme turque $(\mathrm{BnF})$ has a slight trace of the Zangakis' signature (Fig.50). This image includes two women, one wearing the Turkish costume holding a water pipe and the other in an Arab costume holding a tambourine. It is an example of a comparison between the two cultures by portraying different costumes. In Odalisques \& Arabesques Jacobson included a coloured photograph ${ }^{82}$ of two Middle Eastern women (c.1900) transferred to a silk place mat or a handkerchief (Fig.51). This coloured photograph and the albumen print Femme arabe femme turque $(\mathrm{BnF})$ are produced from an identical negative. A mass-produced albumen print such as this one, originally made for tourists in the 1870 s, was reproduced as a very delicate handkerchief or silk place mat decades later in the 1900s. While its first life was as a loose print, the photo evolved into a personal object for the owner.

Osman includes an albumen print [Two Sudanese Women], ${ }^{83}$ which is an image of two girls posed back to back in front of a stone wall (Fig.52). I found a postcard online $^{84}$ that is identical. The inscription on the postcard is Series 647. Edit. The Cairo Post-Card Trust - Ph. N. 010 (Fig.53). Once more one cannot know if this image was printed with the permission of Constantinos or without his knowledge.

An albumen print, Fontaine de Moise el Suez (Marta Braun coll.) is a picturesque image including the fountain of Moses, palm trees and a shadow of a palm tree in the

\footnotetext{
${ }^{82}$ Jacobson, Odalisques \& Arabesques, 195. The dimension of the handkerchief or the silk place mat has not been provided.

${ }^{83}$ Osman, Egypt, 92.

${ }^{84}$ Ebay, "Egypt, Cairo: Sudanese Women. Old and Vintage Postcard," Ebay, http://cgi.ebay.com. sg/Egypt -Cairo-Sudanese-Women-Old-and-vintage postcard_W0QQitemZ380141179489 QQcmdZViewItemQQptZLH_DefaultDomain_216? $\mathrm{hash}=\mathrm{item} 58822 \mathrm{e} 1261$ \&_trksid=p3286.c0.m

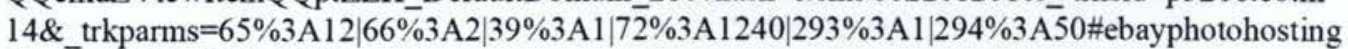
(accessed July 23, 2009)
} 
foreground (Fig.54). I found a postcard online ${ }^{85}$ that is almost identical to it except that the positions are slightly different and the shadow of the palm tree has moved to the middle. This postcard has Peridis' signature on the back inscribed as POST CARDEGYPT, Suez - Fontaine de Moise, 16, P. Peridis-Cairo (Fig.55). On the front is inscribed the title: SUEZ - The Fountain of Moses. This example demonstrates Xanthakis' claim that Peridis bought some of the Zangakis' negatives when their Port Said studio was closed. Lastly, Porteur d'eau $(\mathrm{BnF})$ portrays a water-seller pouring water into one woman's very large water carrier as another looks on (Fig.56). The woman's face is covered with the black burgu and she stares directly into the camera. A postcard found online ${ }^{86}$ is an almost identical only the positions of the subjects are slightly different (Fig.57). The inscription on the postcard is "Ephtimios Frères Port-Said." The changed positions again exemplify the Zangakis' taking more than one picture at each location or of each tableau they created.

There is proof that Constantinos was involved in the creation of at least some of the postcards made from his photographs. [Egpytiennes] $(\mathrm{BnF})$ is an albumen print of two women posing for the camera in the outdoor studio of the Zangakis (Fig.58). It depicts two women, one with a veil carrying a water carrier and one without a veil holding the pipe of a water pipe. Osman includes a postcard ${ }^{87}$ Deux Femmes de Damiette, Damietta Women, which is identical. This postcard has an inscription on the

\footnotetext{
${ }^{85}$ Vintage Postcards \& Stamps, "Vintage Postcards \& Stamps Egypt Old Postcard SUEZ Fountain of Moses \& Palm Trees," Vintage Postcards \& Stamps, http://www.stamps-auction.com/egypt-old-postcardsuez-fountain-of-moses-palm-trees-for-sale-78837 (accessed July 23, 2009)

${ }^{86}$ Ebay, "Egypt Water Porter Vintage Port-Said Egypte postcard," Ebay, http://cgi.ebay.com .sg/EGYPTWater-Porter-Vintage-Port-Said-Egyptepostcard_W0QQitemZ220452657921QQ cmdZViewItemQQptZ LH_DefaultDomain_216?hash=item3354009b01\&_trksid=p $3286 . \mathrm{c} 0 . \mathrm{ml} 4 \&$ _trkparms $=65 \% 3 \mathrm{~A} 12|66 \% 3 \mathrm{~A} 2| 39 \% \overline{3} \mathrm{Al}|72 \% 3 \mathrm{~A} 1240| 293 \% 3 \mathrm{Al} \mid 294 \% 3 \mathrm{~A} 50$ \#ebayphotohosti ng (accessed July 25, 2009).

${ }^{87}$ Osman, Egypt, 137.
} 
bottom left that says "C. Zangaki Photographe" (Fig. 10). This postcard among others is the evidence that Constantinos was in this industry from the beginning to the end. 


\section{PRESERVATION OF VIEWS OF EGYPT}

Views of Egypt is a thin and light album measuring $1.7 \mathrm{~cm} \times 29.1 \mathrm{~cm} \times 39.1 \mathrm{~cm}$. It has both a thin cover and a binding. The binding had weakened, and it was broken in different parts of the album (Fig.59). The leaves are thin and acidic from having been kept in different climates (Fig.60). Out of the forty-six albumen prints, measuring approximately $21.5 \mathrm{~cm}$ by $28 \mathrm{~cm}$, forty-one of them were slotted into the four corner "pockets" on each floppy leaf of the album. Each leaf held two photographs, one in the front and one in the back, by their four corners. However, the leaves could not carry the weight of the prints. The remaining five prints of the forty-six were stacked loosely at the back of the album.

This method for holding photos in place posed the first risk to archival preservation. The corners of several of the photographs were not slotted through properly. There were creases and tears on the corners of the prints and also tears on the floppy leaves (Fig.61 and Fig.62). The reason for this was that when turning the pages, the photographs would slip out of the "pockets." Because of this, the order of the prints was changed many times over the years, and there was no visual or documented record of the original order or the subsequent sequencing. ${ }^{88}$ As Sutnik explains, "Continuous replacements into the "pockets" damaged and kinked the corners of the prints, and hence they were better left loose." 89 After learning that the owner had had to move the prints around several times, Sutnik, Whitman and I agreed that the significance of the original order of the prints had been lost many years ago, and there was therefore little

\footnotetext{
${ }^{88}$ Maia Sutnik, e-mail message to author, July 21, 2009.

${ }^{89}$ Ibid.
} 
justification for keeping the prints in a deteriorating housing. We made a decision to remove the prints from the album.

Although there are creases and tears in the prints, ironically the prints maintain rich tonal values, since they were not mounted to album pages. As Sutnik concludes, "Many mounted prints of the period suffered various kinds of degradation as a result of glues and acidic containment. ${ }^{100}$ Most of the Zangakis' photographs that I have seen in the $\mathrm{BnF}$ and in the $\mathrm{AUC}$ (and most likely in other collections) are faded for three reasons: Their prints were not well preserved because there was no understanding of their images until recent publications on photography of the Middle East, such as Jacobson's. Second, most of the Zangakis' prints were glued on travel album pages and this created various degradations. Third, their photographs were a part of the commercial industry, thus they produced many images quickly; most likely their images were not fixed and washed properly.

\section{INITIAL DIGITIZATION}

After Sutnik, Whitman and I decided to remove the prints from the album; it became necessary to document the process at every stage, so that an accurate record of the album's present order and condition would be preserved. I numbered each page of the album with a pencil on the right bottom corner. Following, I photographed the recto of the prints (in their "pockets") in their present order, in which the owner last assembled them. I used a Nikon Coolpix P5100, 12.1-mega-pixel camera (recording at $3264 \times 2448$ resolution). I also photographed the condition of the album, including damage such as creases and tears caused by its current method of storage.

${ }^{90}$ Ibid. 


\section{ALTERNATIVE HOUSING SOLUTIONS}

After discussing the task with Whitman, she presented a number of alternative housing solutions both for the album and the photographs. Following, I presented the alternative housings to Sutnik. Below are the four alternatives:

1. Prints would be inserted into mylar sleeves with backing boards. Following that, the sleeves would be put in an archival box. The empty album shell would be put in an archival box. These two boxes would be kept together in a vault at the AGO.

2. A pre-made album would be ordered from an archival company, which would later be put into an archival box. The prints would be pasted on the pre-made album pages using wheat starch archival tape around the edges of the prints (in the order that they were last assembled by the owner). The empty album shell would then be put into an archival box.

3. A bookbinder would create an album for the photographs using a wheat starch archival tape surrounding the edges of the prints (in the order that they were last assembled by the owner). The empty album shell would then be put into an archival box.

4. The prints would be matted individually using wheat starch archival tape. The empty album shell would be put in an archival box.

\section{HOUSING PLAN}

Both the physical structure and chemical nature of a photographic object is susceptible to different kinds of damage including acidic fumes, ozone, fluctuating temperatures, humidity, insects, mold, residual chemicals in the print or damage due to 
poor storage conditions and/or mishandling. ${ }^{91}$ It was essential to address which alternative housing would be most suitable for both the photographs and the empty album shell.

After conversations with Sutnik and Whitman, we decided on Option 1. This is a clean and affordable housing solution for albumen prints. Mylar sleeves with backing boards are a standard preservation option for albumen prints. In this approach, the prints would be kept together and researched, as a group the owner had previously amassed. The history of the album remains joined, and in the future the AGO would be able to exhibit these prints individually including the new information found on the Zangakis, Peridis and Georgiladakis.

Consequently I removed the prints from the album and temporarily transferred them into an archival box with interleaving tissue paper. The order of the prints was maintained. I was able to examine the versos of the prints and the full inscriptions of the signatures of the photographers, the titles of the locations and the negative numbers on the prints on the recto.

\section{SECOND DIGITIZATION}

There were three sets of photographs taken after removing the prints from the album, once again with the Nikon Coolpix P5100, 12.1-mega-pixel camera at the same resolution. The following are the three sets: First, the entire photograph; second, Close-up of the signature of the photographer; and, third, close-up of both the negative number and the name of the location.

\footnotetext{
${ }^{91}$ Bertrand Lavédrine, A Guide to the Preventive Conservation of Photograph Collections (Los Angeles: Getty Conservation Institute, 2003), 6.
} 


\section{THE NEW HOUSINGS}

Following the decision regarding new housings for the photographs and for the empty album shell, I measured the prints and the shell. I found the most appropriate measurements for sleeves and archival boxes for the prints and the album at the archival company, Carr MacLean. Appendix D shows which materials were ordered and received from Carr MacLean.

After receiving the order from Carr MacLean, seven $32^{\prime} \times 40^{\prime}$ backing boards were cut into forty-six sheets of 9' $\times 12^{\prime}$ at the Conservation Department. The AGO accession number of the Views of Egypt album is 2008/121. After the removal, each print was given a sub-number from 2008/121.1 to 2008/121.46. These sub-numbers reflect the placement of the prints in the album, when the album came to the AGO. I wrote the prints' accession numbers on the backs of the prints and on the backing boards with a pencil. This was needed to identify the print. Following, I inserted both the print and the backing board in each mylar sleeve. The mylar sleeves were stacked and put into the Hollinger box in the order that they were last assembled by the owner (Fig.63).

I placed the empty album shell into the second Hollinger box and enclosed the album with archival foam to keep it stable (Fig.64). Following, I labeled both of the boxes displaying their AGO accession numbers. These two boxes are now kept together on the metal shelf in the Prints and Drawings vault of the AGO, which also houses the Photography Collection. 


\section{CONCLUSION}

The Views of Egypt album and its photographs by the Zangaki brothers have been the focus of this project. Cataloguing of the Views of Egypt album has resulted in understanding the chronological sequence of the Zangaki brothers' negative numbers and its relation to the locations they traveled in Egypt.

The Zangakis' careers spanned the opening of the Suez Canal in 1869 to postcard production into the 1920 s. Their work is crucial to understanding late-nineteenth century commercial photography in Egypt that supplied Oriental subjects, scenes and picturesque views for the Western tourist. There was already an established market for such imagery from Orientalist paintings and literature, and the Zangakis were prolific photographers who were successful in catering to it. Their prints had enormous longevity and were also printed as postcards. There are at least one thousand five hundred prints in collections today that I know of. However, their highest negative number being 1672 , and assuming that they made at least several prints from each negative, we are left with a much higher number. There are likely to be more prints in existence to be found.

When the Zangakis' photographs were first produced, they functioned as a tourist's souvenir of Egypt, a reminiscence of the Orient. Today, these late-nineteenth century tourist photographic albums and the photographs contained within are visual objects that can help recuperate history. Museums and archives, such as the Art Gallery of Ontario, hold collections that further our understand of the practices behind these photographs, the ancient history of Egypt, the colonization of the East by the West, the establishment of the Oriental genre, the photography and the tourist industry in the late nineteenth century and in the early twentieth century in Egypt. 
Although aesthetics fall outside of the scope of this thesis, I find the Zangakis' photographs unique. When I first saw Views of Egypt at the AGO, I was astonished by the range of subjects and the quality of the photographs. This acquisition needed attention and research needed to be done to find out who the makers of these photographs were and how the album was put together. I expect this thesis to provide the foundation for further research that will generate knowledge and awareness of the Zangaki brothers' work and give them a more prominent place in the history of Middle East commercial photography. 


\section{BIBLIOGRAPHY}

Annuaire Et Almanach Du Commerce Et De L'Industrie De La Magistrature Et De L'Administration Ou Almanach Des 500,000 Adresses De Paris, Des Departements Et Des Pays Etrangers (Firmin Didot Et Bottin Reunis), later merged with Almanach-Bottin. Paris, 1870, 1880,1886-1889, 1890, 1895, 1900, $1910,1920$.

Aubenas, Sylvie and Jacques Lacarrière. Voyage En Orient. Paris: Hazan, 1999.

Baedeker, Karl. Egypt. Handbook for Travellers. Leipzig, London: Dulau, K.Baedeker, 1878, 1889, 1898, 1914.

Baldwin, Gordon. Looking at Photographs. A Guide to Technical Terms. Malibu \& London: The J. Paul Getty Museum \& British Museum Press, 1991.

Barnier, John (ed.). Coming into Focus: A Step-By-Step Guide to Alternative Photographic Printing Processes. San Francisco: Chronicle Books, 2000.

Batchen, Geoffrey. Real Hieroglyphics: Photography and Egypt, 1850-1900. La Jolla, CA: University Art Gallery, University of California, San Diego, 1994.

Beukers, Alan. Introduction to Exotic Postcards: The Lure of Distant Lands by Paul Theroux. New York: Thames \& Hudson, 2007.

Bogdan, Robert and Todd Weseloh. Real Photo Postcard Guide: The People's Photography. Syracuse, N.Y.: Syracuse University Press, 2006.

Bull, Deborah. Up the Nile: A Photographic Excursion, Egypt 1839-1898. New York: C. N. Potter, 1979.

Cambridge University Library. "RCS Photographers Index." Cambridge University Library, Royal Commonwealth Society Library. http://www.lib.cam.ac.uk/rcs photographers/entry.php?id=495 (accessed July 20, 2009).

Canadian Center for Architecture. "Collection Online." Canadian Center for Architecture.http://svrdam.cca.qc.ca/search/bs.aspx?langID=1\#s=zangaki\&p= $1 \& \mathrm{a}=\mathrm{kw} \& \mathrm{nr}=1 \& \mathrm{nq}=1$ (accessed July 24, 2009).

Center for Creative Photography Photograph Collection. "XYZ, An Alphabetical Index to the Photographs in the Center for Creative Photography Photograph Collection Organized by Name of Photographer." Center for Creative Photography.www.creativephotography.org/documents/redbook/xyz.pdf (accessed July 3, 2009). 
Chevedden, Paul E. The Photographic Heritage of the Middle East: An Exhibition of Early Photographs of Egypt, Palestine, Syria, Turkey, Greece, \& Iran, 18491893. Malibu: Undena Publications, 1981.

D'Hooghe, Alain and Marie-Cecile Bruwier. The Great Pyramids of Giza. Paris: ViloPublishers, 2000.

Dobson, Sebastian. Art \& Artifice: Japanese photographs of the Meiji Era: Selections from the Jean S. and Frederic A. Sharf Collection at the Museum of Fine Arts, Boston. Boston, MA: MFA Publications, 2004.

Ebay. "Egypt, Cairo: Sudanese Women. Old and Vintage Postcard." Ebay. http://cgi.ebay.com.sg/Egypt-Cairo-Sudanese-Women-Old-and-vintagepostcard_W0QQitemZ380141179489QQcmdZViewItemQQptZLH_DefaultD omain_21 6 ?hash=item58822el261\&_trksid=p3286.c0.mI4\&_trkparms $=65 \%$ $3 \mathrm{~A} 12|\overline{6} 6 \% 3 \mathrm{~A} 2| 39 \% 3 \mathrm{~A} 1|72 \% 3 \mathrm{~A} 1240| 293 \% 3 \mathrm{~A} 1 \mid 294 \% 3 \mathrm{~A} 50$ \#еbayphotohostin $\mathrm{g}$ (accessed July 23, 2009).

"Egypt Water Porter Vintage Port-Said Egypte Postcard," Ebay, http://cgi.ebay.com.sg/EGYPT-Water-Porter-Vintage-Port-Said-Egypte postcard_W0QQitemZ220452657921QQcmdZViewItemQQptZLH_DefaultD omain_216?hash=item $3354009 \mathrm{~b} 01 \&$ trksid $=\mathrm{p} 3286 . \mathrm{c} 0 . \mathrm{ml}$ l4\&_trkparms $=65 \%$ $3 \mathrm{~A} 12|66 \% 3 \mathrm{~A} 2| 39 \% 3 \mathrm{~A} 1|72 \% 3 \mathrm{~A} 1240| 293 \% 3 \mathrm{~A} 1 \mid 294 \% 3 \mathrm{~A} 50$ \# g (accessed July 25, 2009).

The Egyptian Directory. Annuaire Complet Du Commerce, De L'Industrie, De L'Administration Et De La Magistrature De L'Egypte Contenant Les Renseignements, Addresses Et Professions des 20 Principales Villes De L'Egypte. Cairo, 1911,1912, 1914 -1922, 1925.

George Eastman House. "Selected Topographics." George Eastman House. http://www.geh.org/fm/topographics/topog_sum00001.html (accessed July 20, 2009).

Graham-Brown, Sarah. Images of Women: The Portrayal of Women in Photography of the Middle East 1860-1950. London: Quartet Books Limited, 1988.

The Griffith Institute. " $19^{\text {th }}$ Century Studio Photographs of Egypt." Archive of the Griffith Institute. http://www.lib.uchicago.edu/e/su/mideast/photo/Egypt.html\# (accessed July 3, 2009).

Hamilton, Jill. Thomas Cook: The Holiday Maker. Stroud, Gloucestershire: Sutton Pub., 2005.

Hannavy, John (ed.). Encyclopedia of Nineteenth-Century Photography, Vol 1-2. New York: Taylor \& Francis, 2008. 
Howe, Kathleen Stewart, and Michael Wilson. Excursions along the Nile: The Photographic Discovery of Ancient Egypt. University of New Mexico: Native American Studies, 1994.

Jacobson, Ken. Odalisques \& Arabesques: Orientalist Photography 1839-1925. London: Quaritch, 2007.

Lavédrine, Bertrand. A Guide to the Preventive Conservation of Photograph. Los Angeles: Getty Conservation Institute, 2003.

Lyons, Claire; John K. Papadopoulos; Lindsay S. Stewart; Andrew Szegledy Maszak. Antiquity and Photography: Early Views of Ancient Mediterranean Sites. Los Angeles: The J. Paul Getty Museum, 2005.

MacCannell, Dean. The Tourist: A New Theory of the Leisure Class. New York: Schocken Books, 1976.

Mariette-Bey, Auguste. The Monuments of the Upper Egypt: A Translation of the Itinéraire de la Haute-Égypte. Translated by Alphonse Mariette. Boston: J.H. Mansfield \& J.W. Dearborn, 1890.

Maxwell, Anne. Colonial Photography and Exhibitions: Representations of the 'Native' and the Making of European Identities. London: Leicester University Press, 1999.

Murnane, William J. The Penguin guide to ancient Egypt. Harmondsworth, Middlesex, England; New York, N.Y.: Penguin Books, 1983.

Murray, John. A Handbook for Travellers in Lower and Upper Egypt. London: John Murray, 1888, 1891.

Naef, Weston. Early Photographers in Egypt and the Holy Land. New York: Metropolitan Museum, 1973.

Nir, Yeshayahu. The Bible and the Image: The History of Photography in the Holy Land, 1839-1899. Philadelphia: University of Pennsylvania Press, 1985.

Osman, Colin. Egypt: Caught in Time. Reading, England. Garnet Publishing, 1997.

Ozendes, Engin. Abdullah Freres: Ottoman Court Photographers. Istanbul: Yapi Kredi Culture, Art Publications, 1998.

From Sebah \& Foaillier to Foto Sabah, Orientalism in Photography. Istanbul: Yapi Kredi Culture, Art Publications, 1999. 
Perez, N. Nissan. Focus East: Early Photography in the Near East 1839 - 1885. New York, N.Y.: Harry N. Abrams, and the Dimino Press Jerusalem, The Israeli Museum, Jerusalem, 1988.

Poffandi, Stefano G (ed.). Indicateur Egyptien Administratif Et Commercial. AlexandriaL L. Carriere, 1897.

Rammant-Peeters, A. (ed.) and Palmen en Tempels. Fotografie in Egypte in de XIXe eeuw, La photographie en Egypte au XIXe siècle/19th-Century Photography in Egypt. Leuven: Peeters, 1994.

Reilly, James M. Care and identification of 19th-Century Photographic Prints. NewYork: Eastman Kodak Company, 1986.

Ritzenthaler, Mary Lynn. Photographs: Archival Care and Management. Chicago: Society of American Archivists, 2006.

Said, Edward. Orientalism. London: Routledge and Kegan Paul, 1978.

Spiro, Lisa. Travelers in the Middle East Archive. "Leading Nineteenth Century Publishers of Travel Guidebooks to Egypt." http://cnx.org/content/m15453/ latest/ (accessed July 24, 2009).

The University of Chicago Library. "Middle East Photos, Photograph Archive: Egypt." The University of Chicago Library. http://www.lib.uchicago.edu /e/su/mideast/photo/Egypt.html\# (accessed July 3, 2009).

Vaczek, Louis, and Gail Buckland. Travelers in Ancient Lands: A Portrait of the Middle East 1839 - 1919. Boston, Mass: New York Graphic Society, 1981.

Valverde, Maria Fernanda. Photographic Negatives: Nature and Evolution of Processes. Rochester: International Museum of Photography and Film, George Eastman House, 2005.

Vintage Postcards \& Stamps. "Vintage Postcards \& Stamps Egypt Old Postcard SUEZ Fountain of Moses \& Palm Trees." Vintage Postcards \& Stamps, http://www.stamps-auction.com/egypt-old-postcard-suez-fountain-of-mosespalm-trees-for-sale-78837 (accessed July 23, 2009).

Weinberg, Adam. Majestic Inspirations, Incomparable Souvenirs: 19th Century Photographs of the Mediterranean and the Middle East. Rose Art Museum, Brandis University, 1977.

Xanthakis, Alkis X. The History of Greek Photography 1839-1960. Athens: Hellenic Literary and Historical Society, 1988. 
The History of Greek Photography 1839-1970, (139-142). Unpublished translation by Myrto Koumarianos. Athens: Hellenic Literary and Historical Society, 2008.

. "Zangaki Brothers: Two Creative Greek Photographers in Egypt." Unpublished translation by Myrto Koumarianos. Athens, Fotografos vol.141, (2005): 62 64. 


\section{APPENDIX A:}

\section{FIGURES}




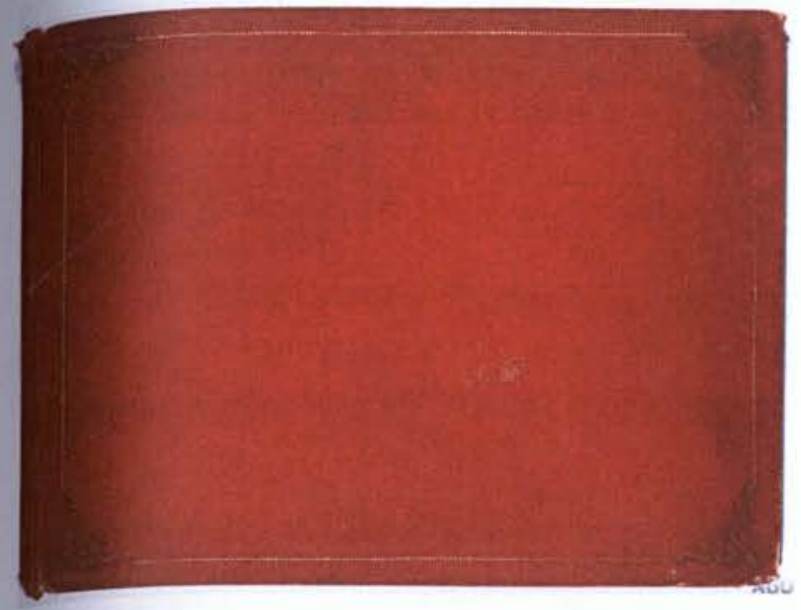

Fig. 1

Views of Egypt, ca. 1880

Red leather with gold painted border and embossed detailing on four corners containing 50 pages with 46 albumen prints

AGO: 2008/121

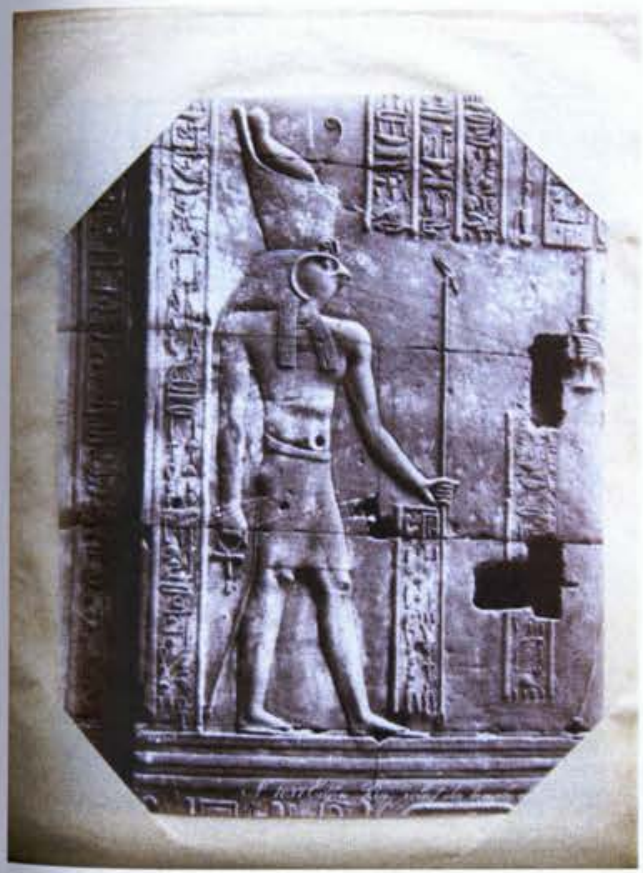

Fig. 2

Zangaki brothers (Georgios Zangaki, ca.1845-ca.1895,

Constantinos Zangaki, ca.1845-1916)

Edfou Bas-relief du temple de Horus, ca. 1880

Albumen print

$21.5 \times 27.7 \mathrm{~cm}$

No.1037, in the Views of Egypt album, AGO: 2008/121.30

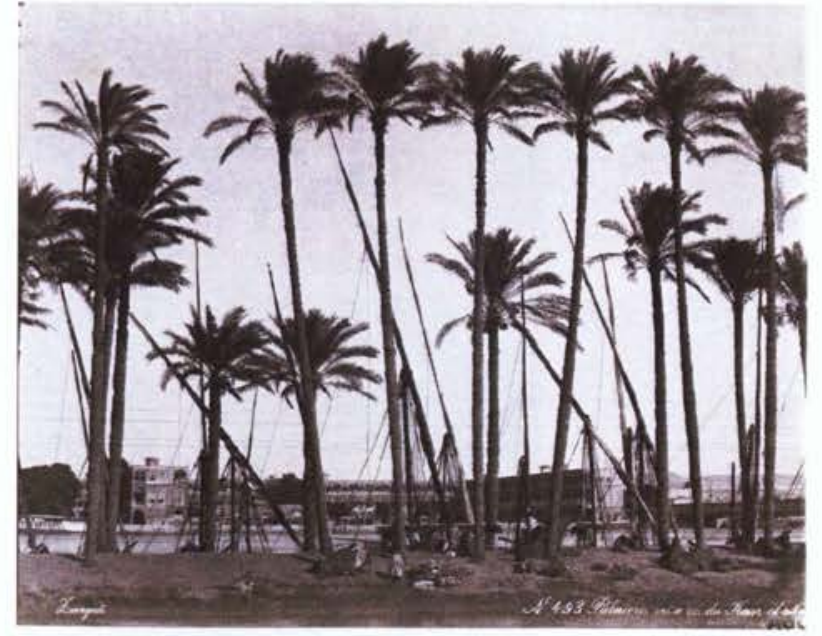

Fig. 3

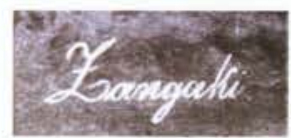

Fig. 4

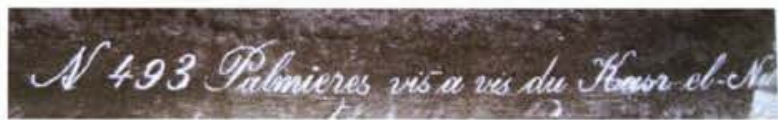

Fig. 5

Fig. 3

Zangaki brothers (Georgios Zangaki, ca. 1845-ca.1895, Constantinos Zangaki, ca.1845-1916)

Palmieres [sic] vis a vis[sic] du Kasr-el-Nil, ca.1880

Albumen print

$21.8 \times 28 \mathrm{~cm}$.

No.493, AGO: 2008/121.38

Fig. 4

Zangaki brothers (Georgios Zangaki ca.1845-ca.1895, Constantinos Zangaki, ca.1845-1916)

Palmieres [sic] vis a vis[sic] du Kasr-el-Nil, detail of signature, ca. 1880

Albumen print

$21.8 \times 28 \mathrm{~cm}$.

No.493, AGO: 2008/121.38

Fig. 5

Zangaki brothers (Georgios Zangaki, ca. 1845-ca.1895, Constantinos Zangaki, ca.1845-1916)

Palmieres [sic] vis a vis [sic] du Kast-el-Nil, detail of negative number and title, ca. 1880

Albumen print

$21.8 \times 28 \mathrm{~cm}$.

No.493, AGO: 2008/121.38 


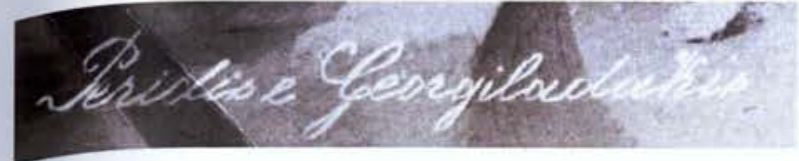

Fig. 6

Pappa Peridis (active ca.1890-1905), Georgiladakis (active ca.1890-ca.1910)

Ramseon Luxor; detail of signature, ca.1890

Albumen print

$21.9 \times 28.2 \mathrm{~cm}$

No. 1030 , AGO: $2008 / 121.14$

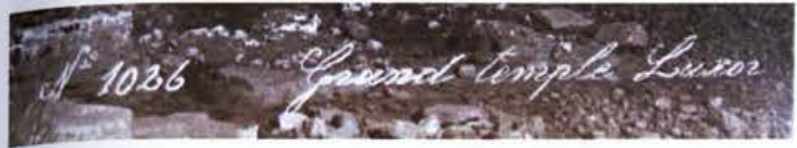

Fig. 7

Pappa Peridis (active ca.1890-1905), Georgiladakis (active ca.1890-ca.1910)

Grand temple Luxor, detail of negative number and title.

ca. 1890

Albumen print

$21.6 \times 27.9 \mathrm{~cm}$.

No.1026, AGO: 2008/121.16

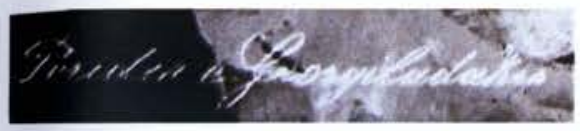

\section{Fig. 8}

Pappa Peridis (active ca.1890-1905), Georgiladakis (active ca.1890-ca.1910)

[...] Karnac, detail of signature, ca. 1890

Albumen print

$21.8 \times 27.9 \mathrm{~cm}$

No.1060, AGO: 2008/121.21

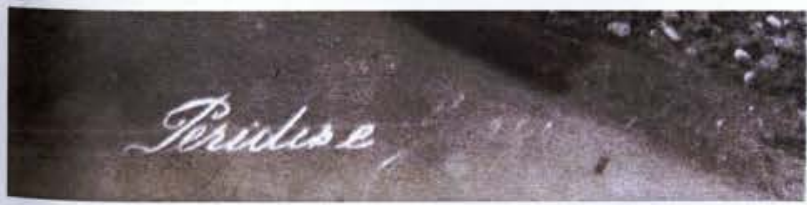

Fig. 9

Pappa Peridis (active ca.1890-1905), Georgiladakis (active ca.1890-ca.1910)

Grand temple Luxor, detail of signature, ca.1890

Albumen print

$21.6 \times 27.9 \mathrm{~cm}$.

No.1026, AGO: 2008/121.16

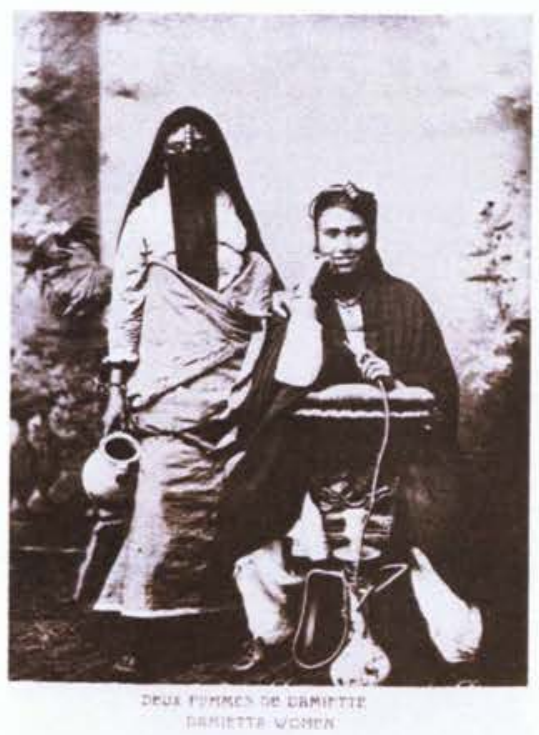

Fig. 10

Constantinos Langaki (ca.1845-1916), Deux Femmes de Damietta, Damietta Women, ca.1900

No.1542, in Osman 1997 (137)

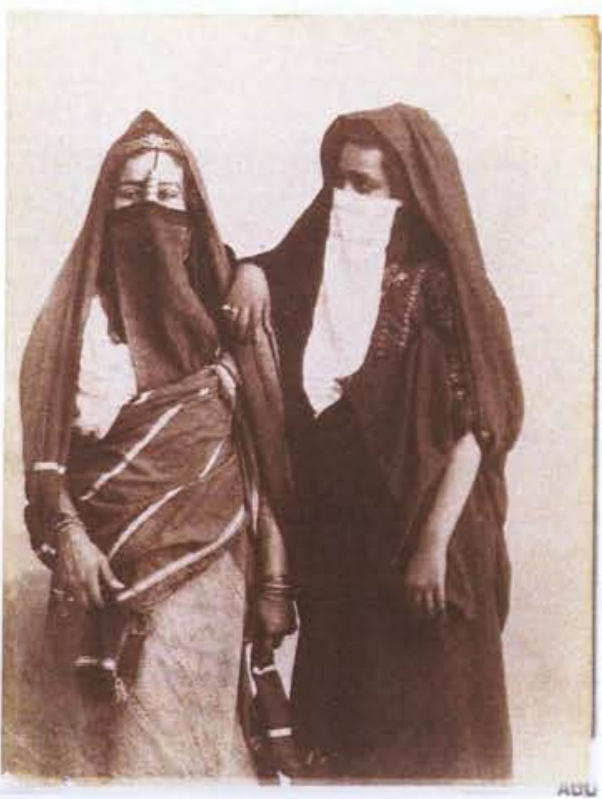

Fig. 11

Zangaki brothers (Georgios Zangaki, ca.1845-ca.1895,

Constantinos Zangaki, ca.1845-1916)

[Two Middle Eastern Women], ca.1880

Albumen print

$21.7 \times 28.2 \mathrm{~cm}$

No.11, AGO: 2008/121.2 


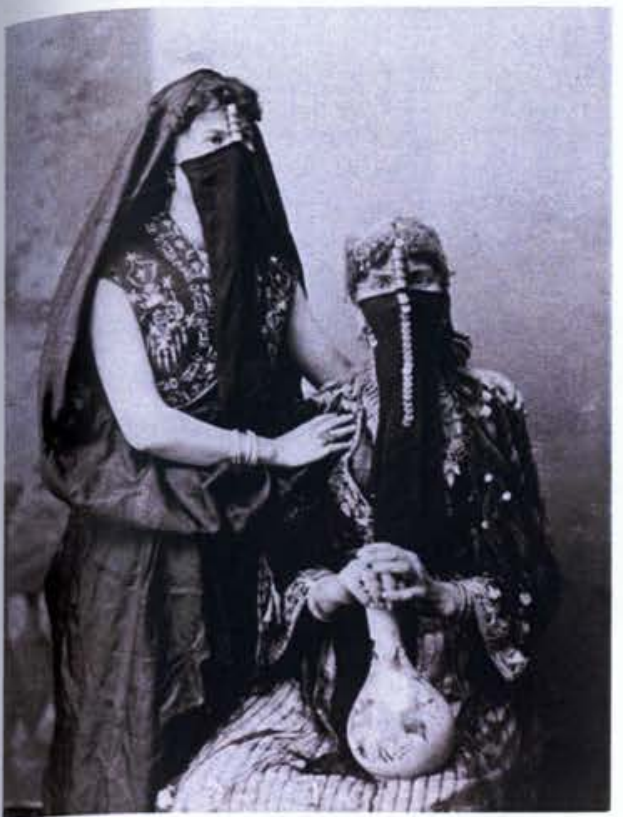

Fig. 12

Zangaki brothers (Georgios Zangaki, ca.1845-ca. 1895 , Constantinos Zangaki, ca.1845-1916)

Deux femmes arabes, ca. 1880

Albumen print

No.737, UCL: 259-61

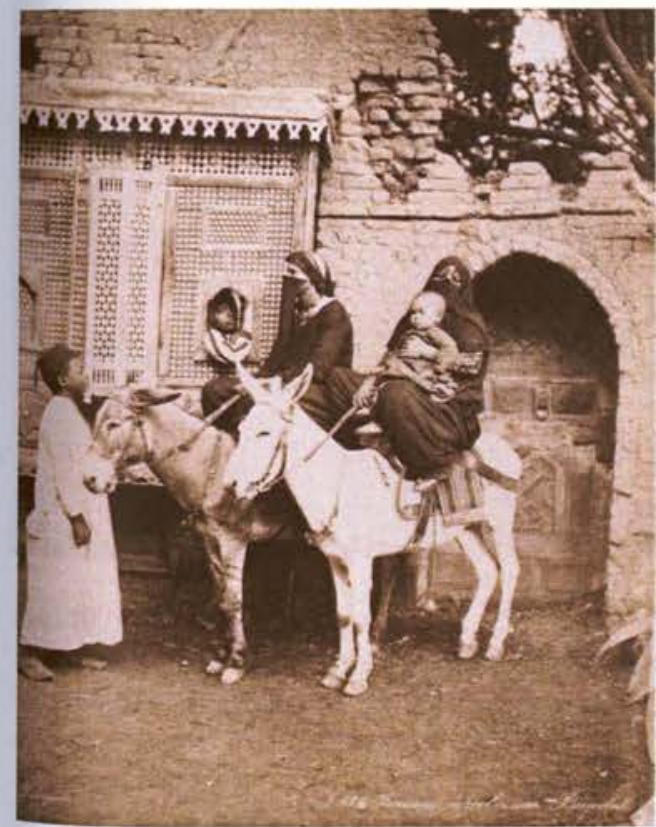

Fig. 13

Zangaki brothers (Georgios Zangaki, ca.1845-ca.1895,

Constantinos Zangaki, ca.1845-1916)

Femmes arabes sur Baudets, ca. 1880

Albumen print

No. 576, GEH: 1983:1317:0003

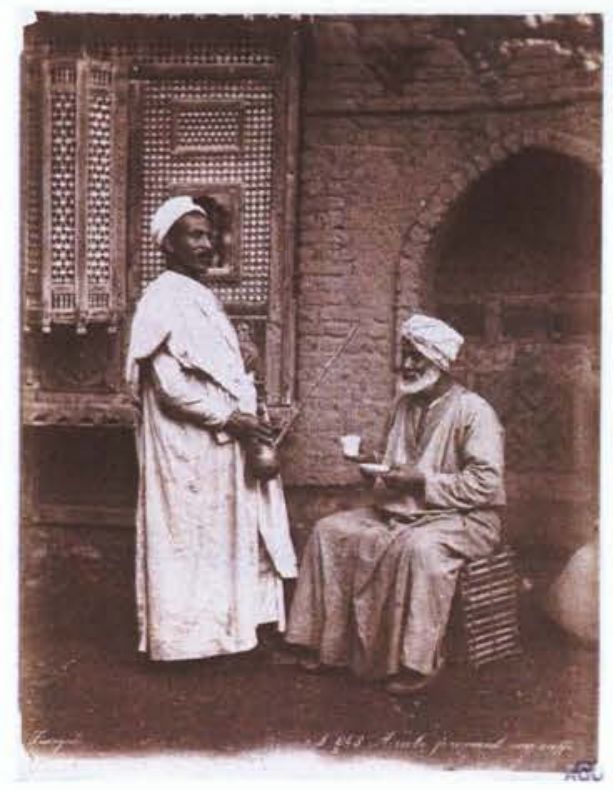

Fig. 14

Zangaki brothers (Georgios Zangaki, ca.1845-ca. 1895 , Constantinos Zangaki, ca.1845-1916) Arabe prenant son caffe[sic], ca. 1880

Albumen print

$21.8 \times 28.1 \mathrm{~cm}$.

No. 643 , AGO: 2008/121.6

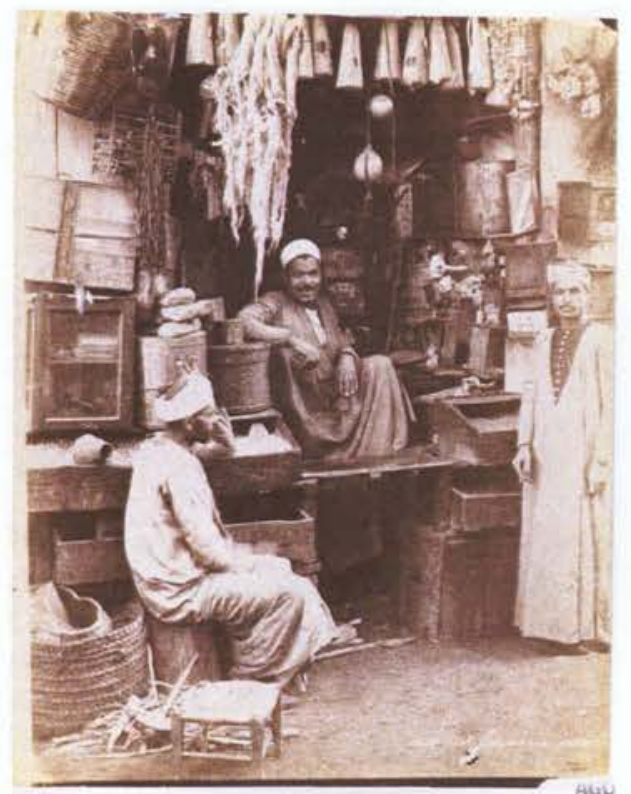

Fig. 15

Zangaki brothers (Georgios Zangaki, ca.1845-ca.1895,

Constantinos Zangaki, ca.1845-1916)

Epicerie[sic] arabe, ca. 1880

Albumen print

$22.1 \times 28.2 \mathrm{~cm}$

No.608, AGO: $2008 / 121.8$ 


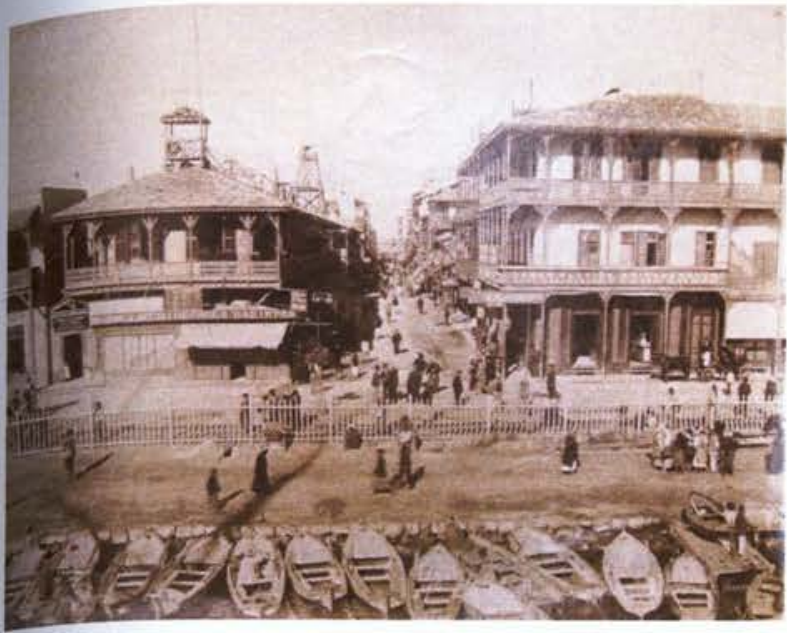

Fig. 16

Zangaki brothers (Georgios Zangaki, ca.1845-ca.1895, Constantinos 7angaki,

ca. 1845-1916)

Rue de com[erce a] [sic] Port Said, ca.1880

Albumen print

No.34, BnF: 40492256, EO-487-BOITE FOL B

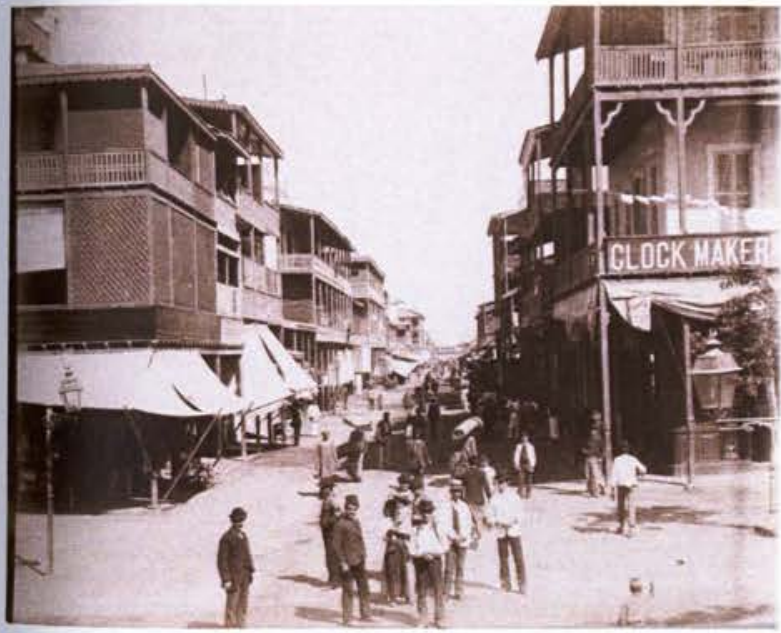

Fig. 17

Zangaki brothers (Georgios Zangaki, ca.1845-ca.1895,

Constantinos Zangaki, ca.1845-1916)

Rue du comerce a [sic] Port-Said, ca. 1880

Albumen print

No.458, GEH: 2001:1522:0007

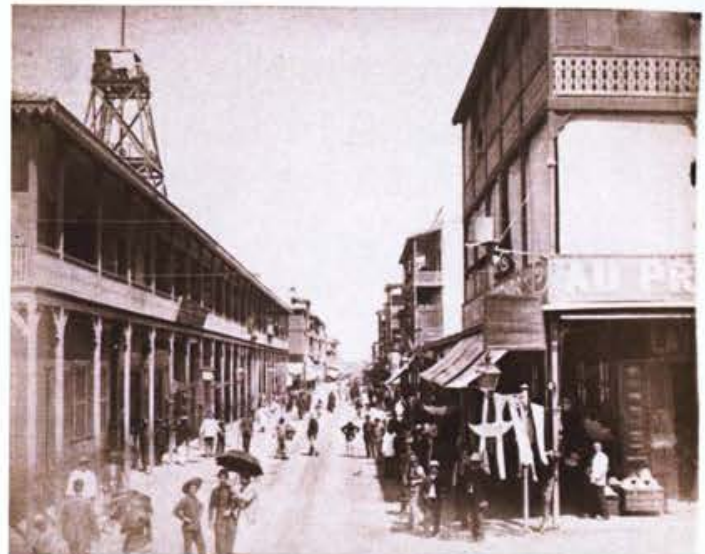

Fig. 18

Zangaki brothers (Georgios Zangaki, ca.1845-ca.1895, Constantinos Zangaki, ca.1845-1916)

Rue du comerce a[sic] Port-Said, ca. 1880

Albumen print

$21.4 \times 27.7 \mathrm{~cm}$

No. 456, GEH: 2001:1522:0007

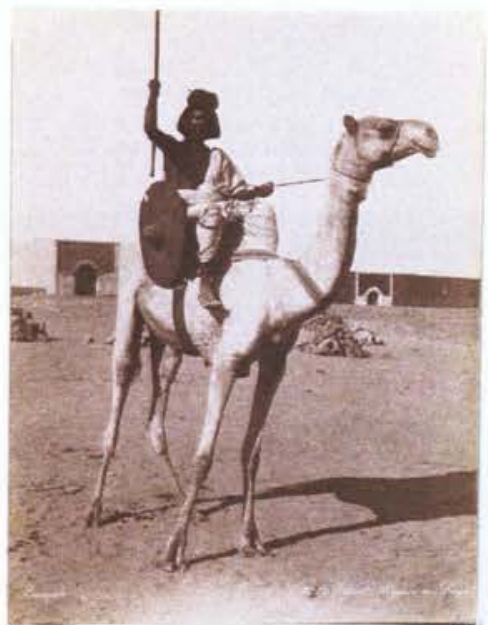

Fig. 19

Zangaki brothers (Georgios Zangaki, ca.1845-ca.1895, Constantinos Zangaki, ca.1845-1916)

Soldat Abyssin a [sic] Dogali, ca. 1880

Albumen print

No. 521, AGO: 2008/121.40 


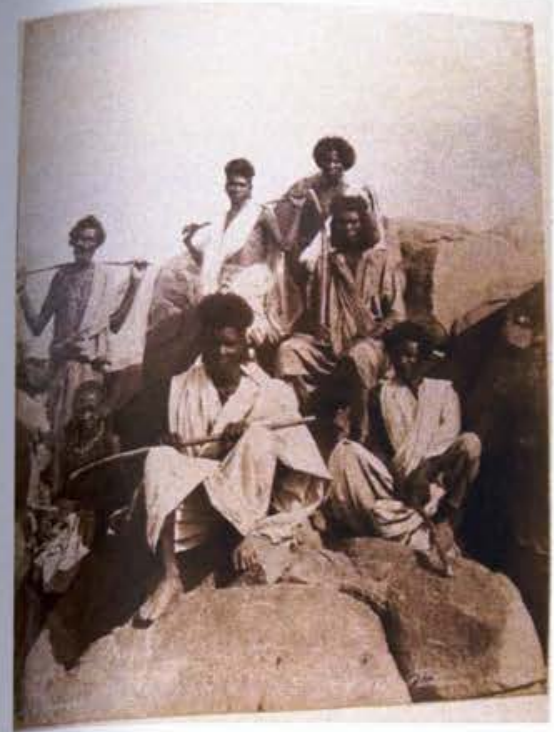

Fig. 20

Zangaki brothers (Georgios Zangaki, ca.1845-ca.1895,

Constantinos Zangaki, ca.1845-1916)

[Bicharins...], ca. 1880

Albumen print

No.517, BnF: 40492256, EO-487-BOITE FOL B

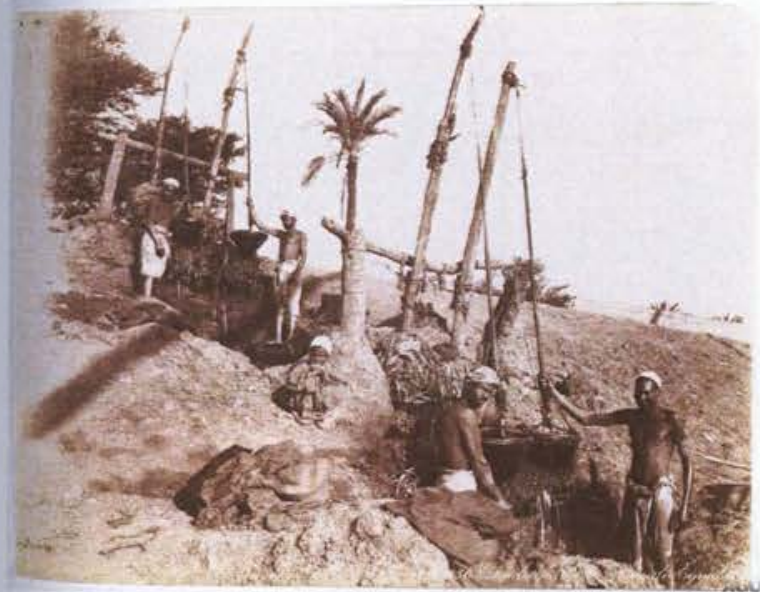

Fig. 21

Zangaki brothers (Georgios Zangaki, ca.1845-ca.1895,

Constantinos Zangaki, ca.1845-1916)

Chadoufs de la haute[sic] Egvpte[sic], ca.1880

$21.4 \times 27.7 \mathrm{~cm}$.

Albumen print

No.630, AGO: 2008/121.41

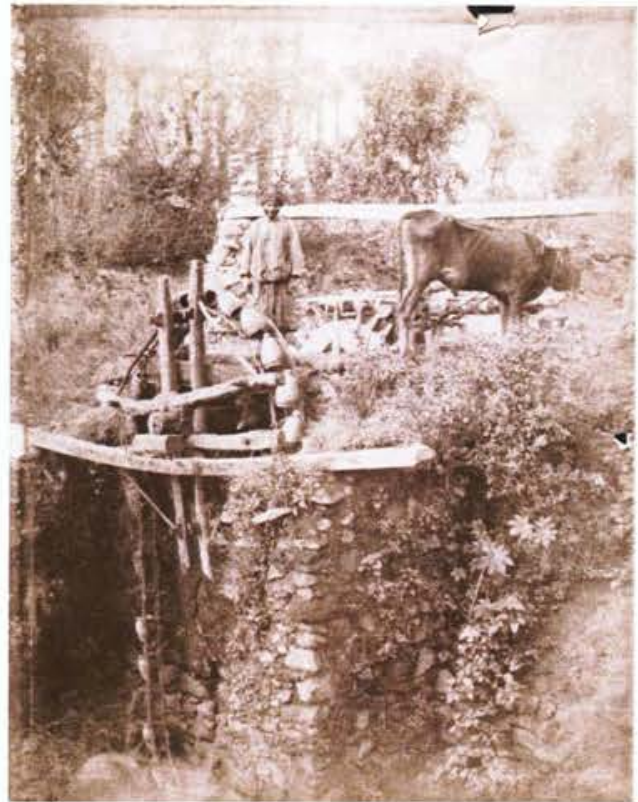

Fig. 22

Zangaki brothers (Georgios Zangaki, ca.1845-ca.1895, Constantinos Zangaki, ca.1845-1916)

Saqqieh Egyptiene [sic], ca.1880

Albumen print

No.540, GEH: 2000:0814:0015

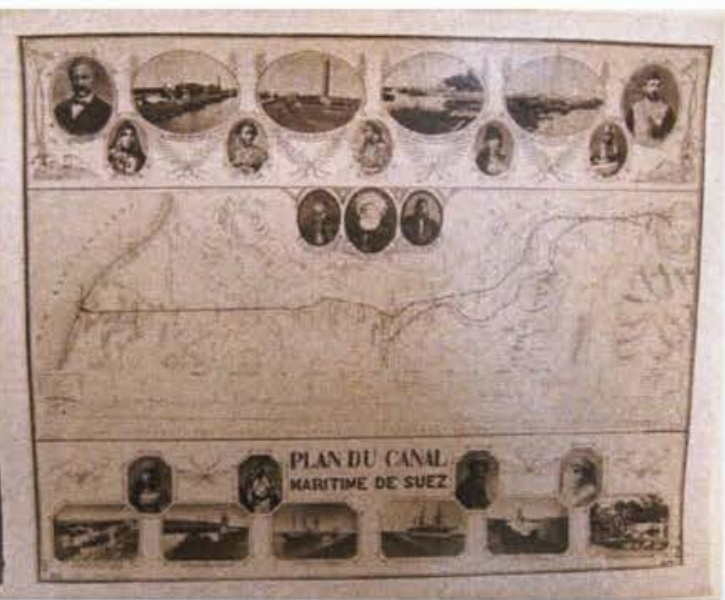

Fig. 23

Zangaki brothers (Georgios Zangaki, ca.1845-ca.1895, Constantinos Zangaki, ca.1845-1916)

Plan du Canal, Maritime de Suez, ca. 1870

Albumen print

Unnumbered, BnF: 40492256, EO-487-BOITE FOL B 


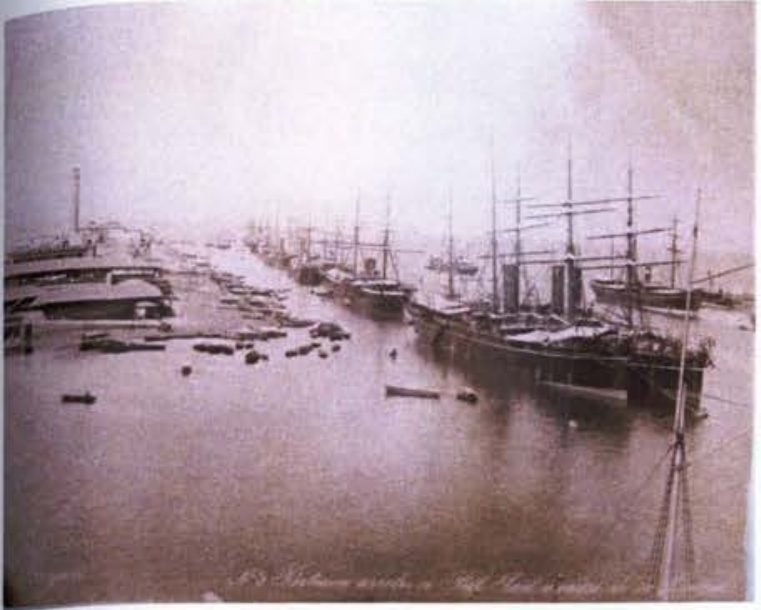

Fig. 24

Zangaki brothers (Georgios Zangaki, ca.1845-ca.1895, Constantinos Zangaki, ca.1845-1916)

Bateaux arêtes [sic] a Port Said a [sic] cause de la Drague, ca. 1870

Albumen print

No.9, BnF: 40492256, EO-487-BOITE FOL B

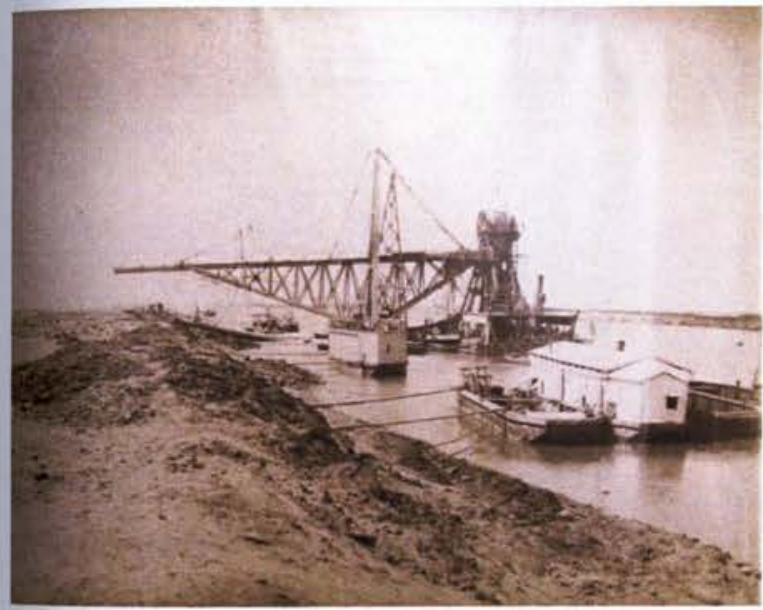

\section{Fig.25}

Zangaki brothers (Georgios Zangaki, ca.1845-ca.1895,

Constantinos Zangaki, ca.1845-1916)

Drague a'longue [sic] eculaine, ca. 1870

Albumen print

No.461, BnF: 40492256, EO-487-BOITE FOL B

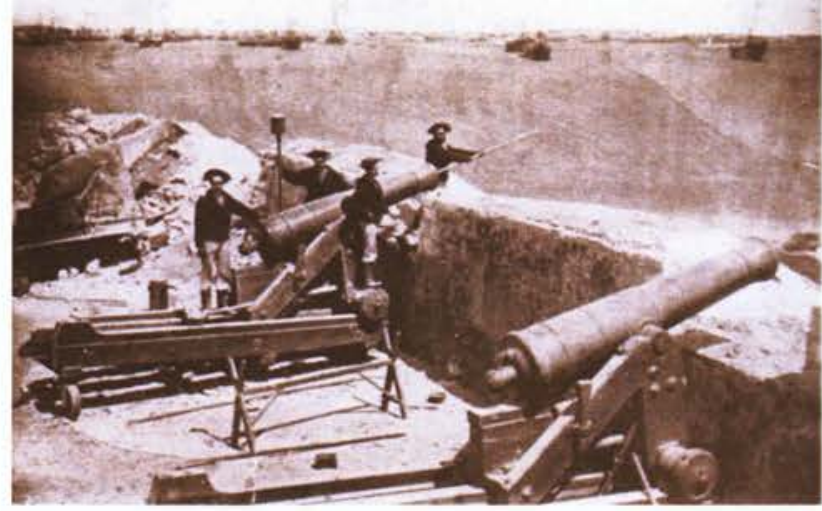

Fig. 26

Anon., Probably Zangaki brothers (Georgios Zangaki, ca.1845-ca.1895, Constantinos Zangaki, ca.1845-1916) [Aftermath of bombardment in Alexandria in 1882], after 1882

Albumen print

Unknown number, in Osman 1997 (70)

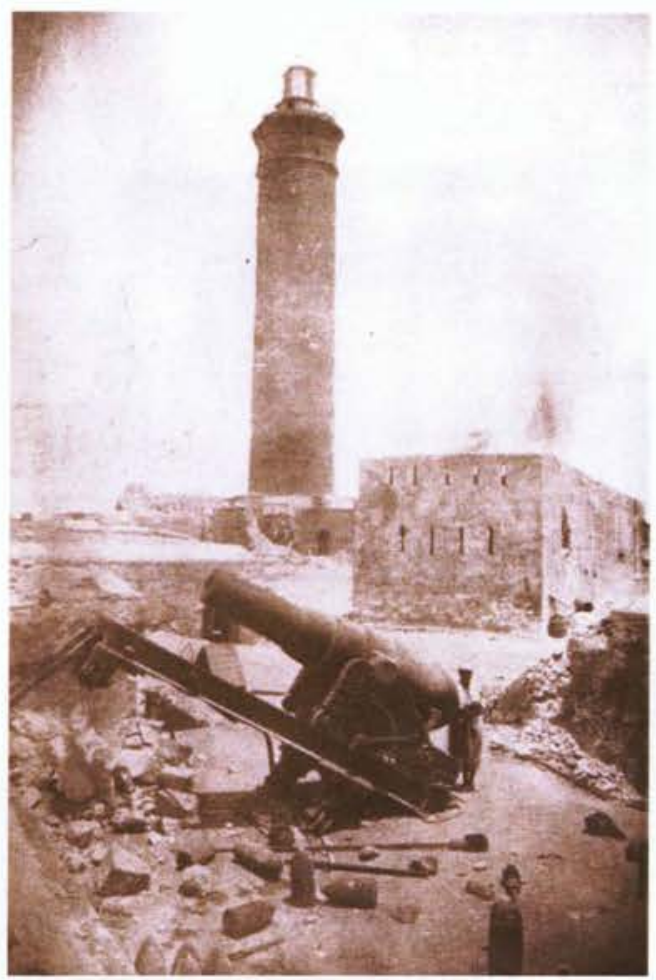

Fig. 27

Anon., Probably Zangaki brothers (Georgios Zangaki, ca.1845-ca.1895, Constantinos Zangaki, ca.1845-1916) [Aftermath of bombardment in Alexandria in 1882], after 1882

Albumen print

Unknown number, in Osman 1997 (71) 


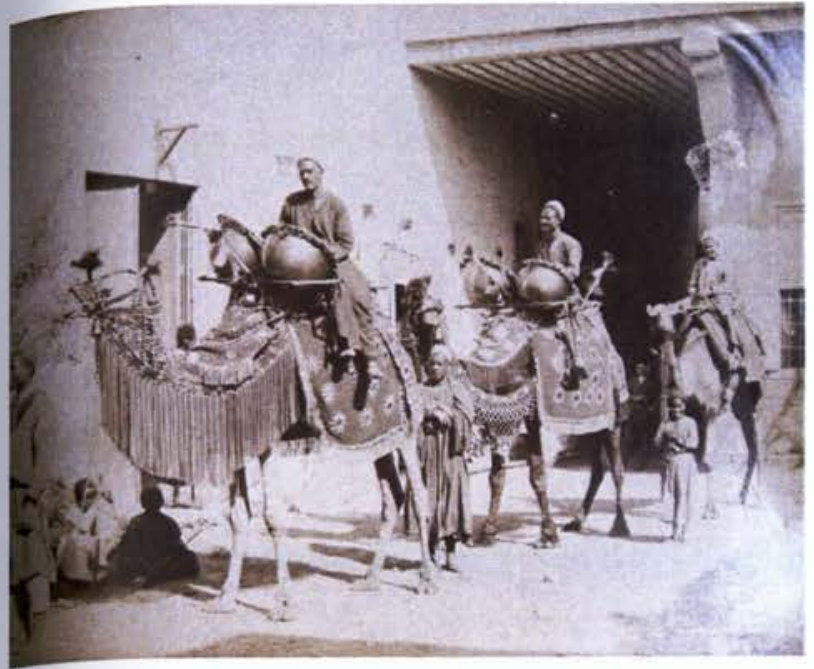

Fig. 28

Zangaki brothers (Georgios Zangaki, ca.1845-ca.1895, Constantinos Zangaki, ca.1845-1916)

Chameaux de mariage arabe, ca. 1890

Albumen print

No. 472, Marta Braun Coll.

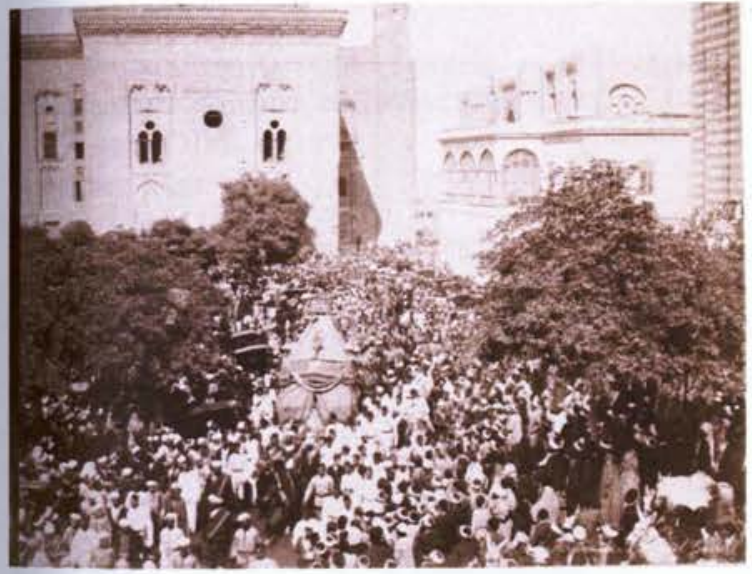

Fig. 29

Zangaki brothers (Georgios Zangaki, ca.1845-ca.1895,

Constantinos Zangaki, ca.1845-1916)

Arivee[sic] du M[ahmel] Caire, ca. 1890

Albumen print

No.849, GEH: 1981:2126:0002

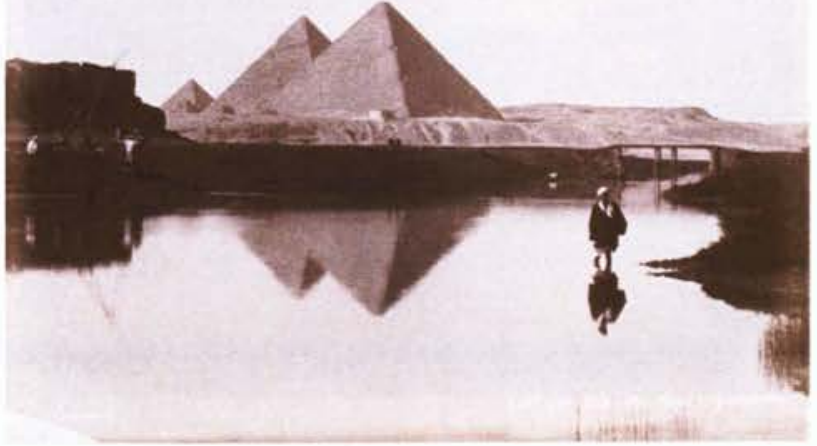

Fig. 30

7angaki brothers (Georgios 7angaki, ca.1845-ca.1895, Constantinos Zangaki, ca.1845-1916)

Vue des trois Pyramides, ca. 1880

Albumen print

No.376, GEH: 2001:1522:0016

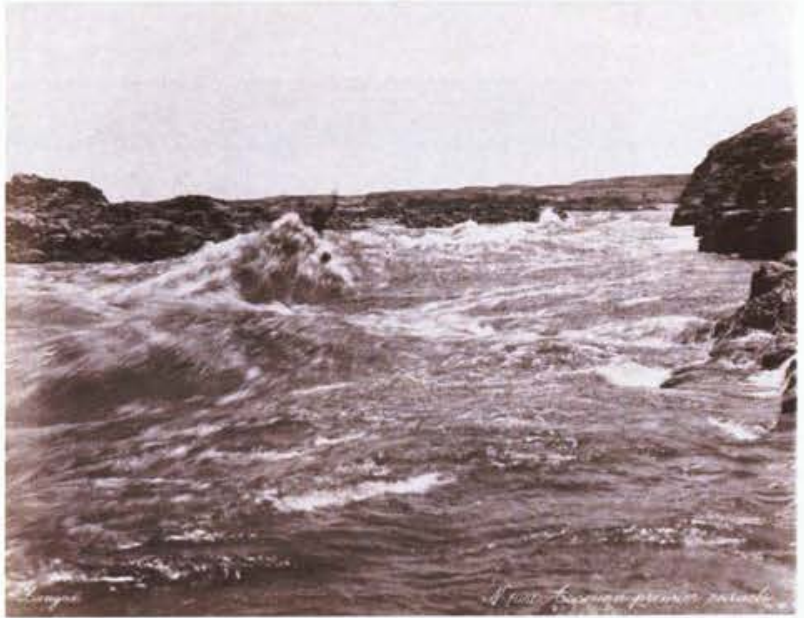

Fig. 31

Zangaki brothers (Georgios Zangaki, ca.1845-ca.1895, Constantinos Zangaki, ca.1845-1916) Assouan premier caracte [sic], ca. 1880

Albumen print

$21.5 \times 27.5 \mathrm{~cm}$.

No.1056, AGO: 2008/121.34 


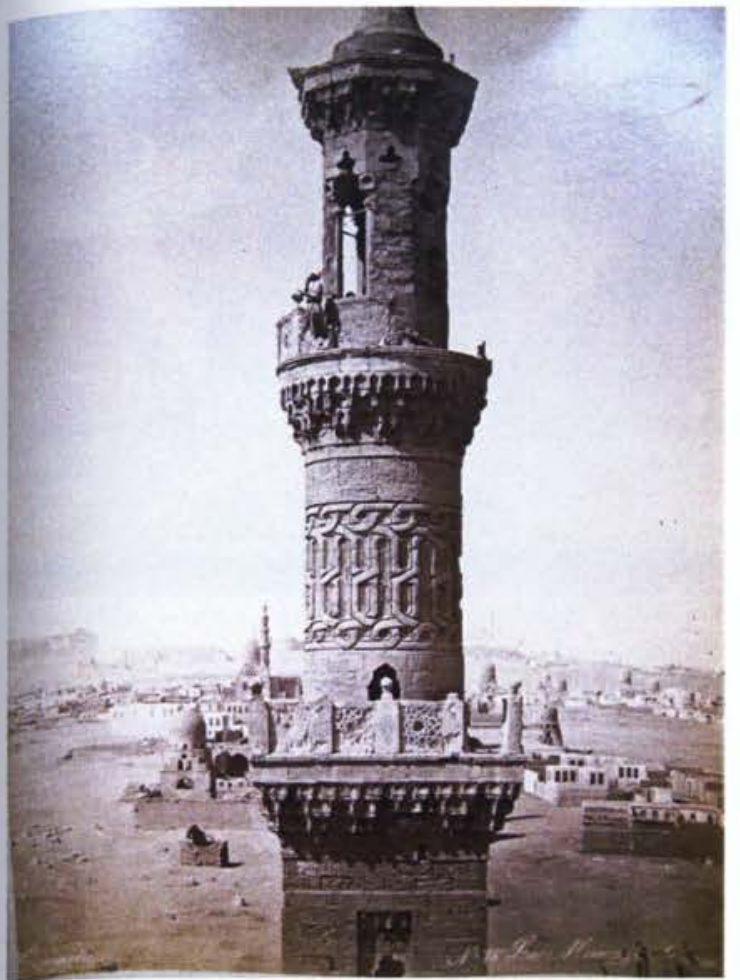

Fig. 32

Zangaki brothers (Georgios Zangaki, ca.1845-ca.1895, Constantinos Zangaki, ca. 1845-1916)

Le Muezzu Caire, ca. 1890

Albumen print

No.78, Marta Braun Coll.

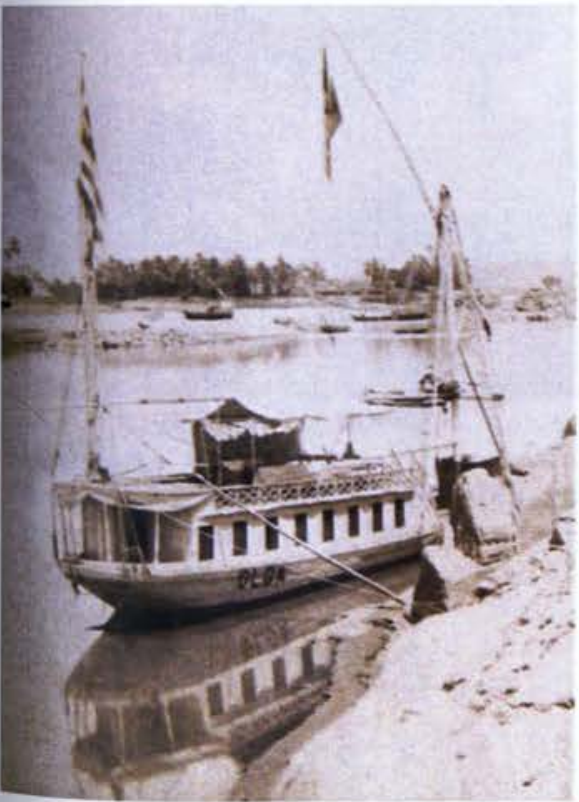

Fig. 33

Zangaki brothers (Georgios Zangaki, ca.1845-ca.1895,

Constantinos Zangaki, ca.1845-1916)

Assouan Nile [...], detail of Olga, ca. 1890

Albumen print

No.792, Marta Braun Coll.

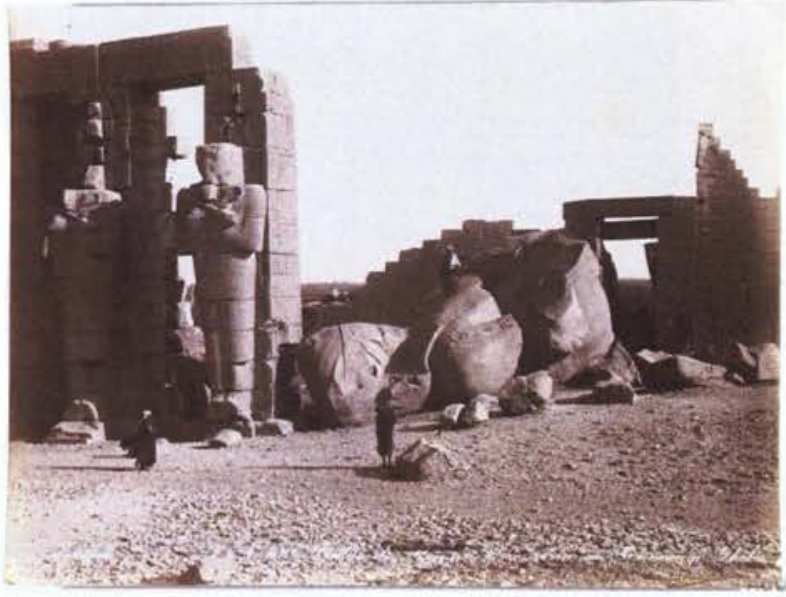

Fig. 34

Zangaki brothers (Georgios Zangaki, ca.1845-ca.1895,

Constantinos Zangaki, ca.1845-1916)

Statue de Ramses III [....see] du Ramesseum Thebes, ca. 1880

Albumen print

$21.4 \times 28.2 \mathrm{~cm}$.

No.926, AGO: 2008/ 121.9

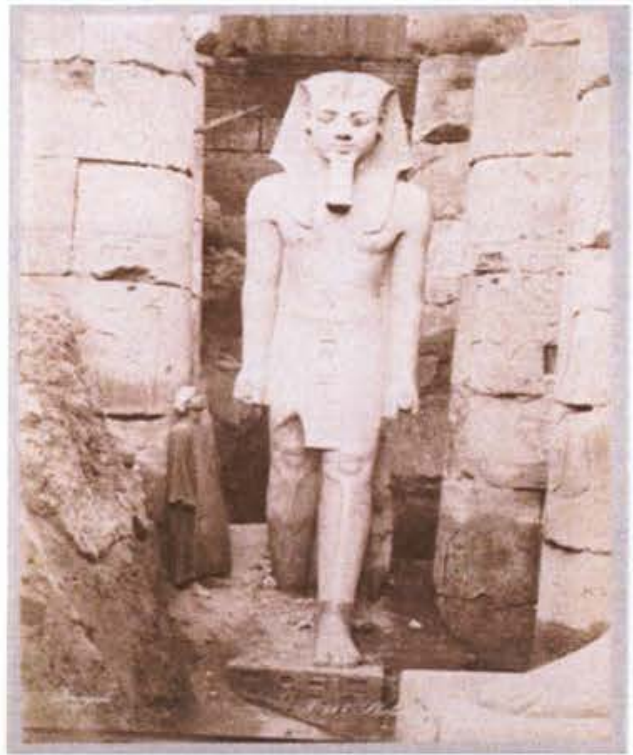

Fig. 35

Zangaki brothers (Georgios Zangaki, ca.1845-ca.1895,

Constantinos Zangaki, ca.1845-1916)

Statue de Ramses a [sic] Louqsor [sic], ca. 1880

Albumen print

No.646, GEH: 1978:1297:0020 


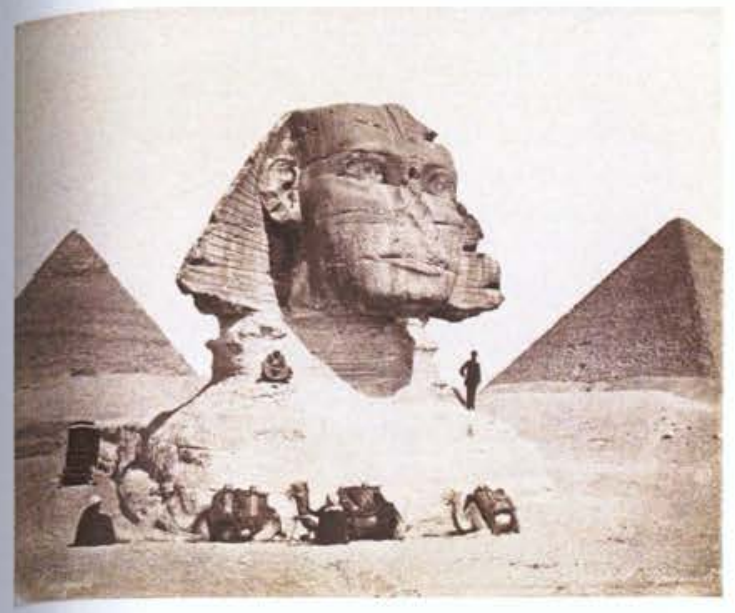

Fig. 36

Zangaki brothers (Georgios Zangaki, ca.1845-ca.1895, Constantinos Zangaki, ca.1845-1916)

Le Sphynx et Pyramide, between 1865 and 1885

Albumen print

$22.7 \times 27.7 \mathrm{~cm}$.

No.106, AGO: 2008/121.47

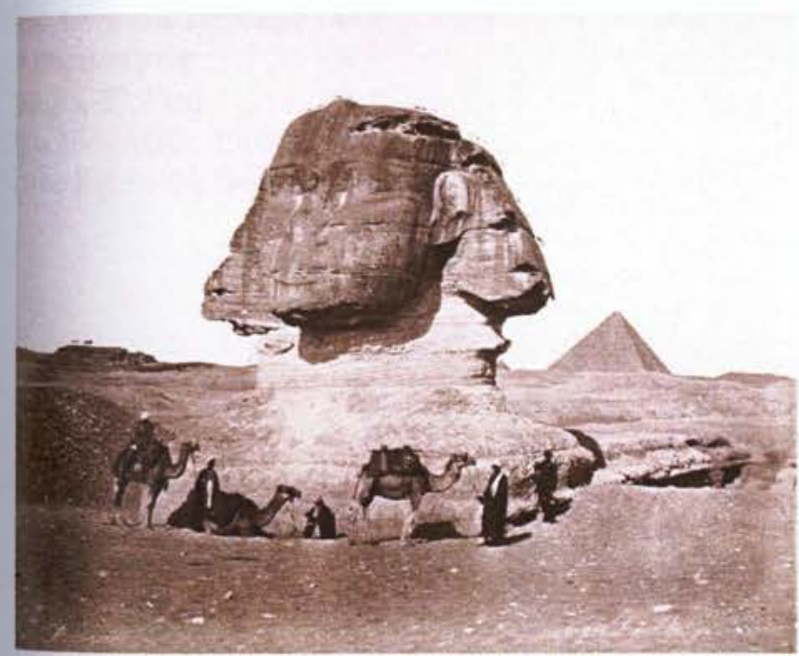

Fig. 37

Zangaki brothers (Georgios Zangaki, ca.1845-ca.1895, Constantinos Zangaki, ca.1845-1916)

Le Sphynx Caire, between 1865 and 1885

Albumen print

No.206, GEH: 2001:1522:0015

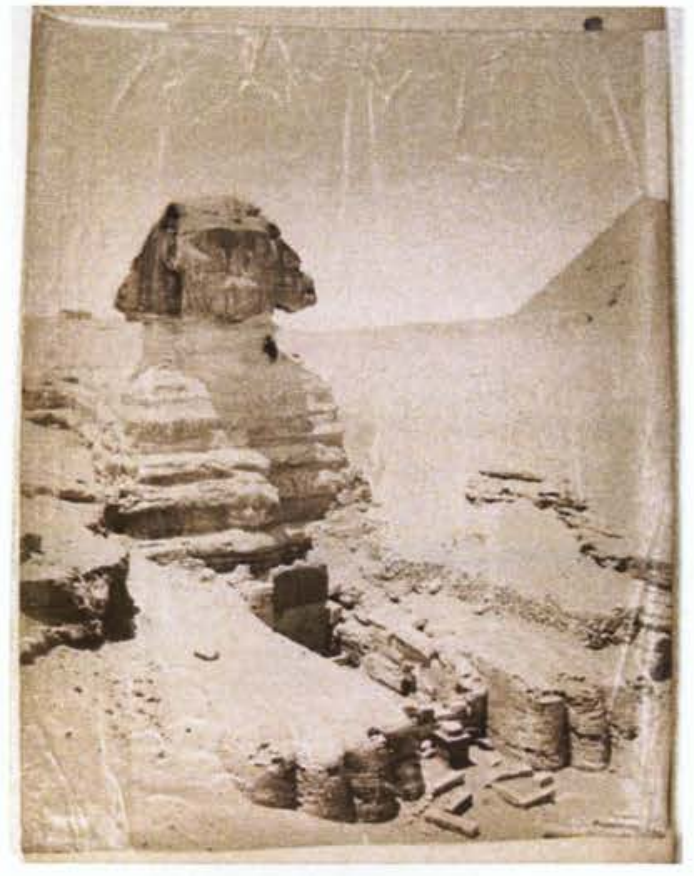

Fig. 38

Zangaki brothers (Georgios Zangaki, ca.1845-ca.1895, Constantinos Zangaki, ca.1845-1916)

[Le Sphinx], after 1885

Albumen print

Unnumbered, AUC: 19 th century photographs

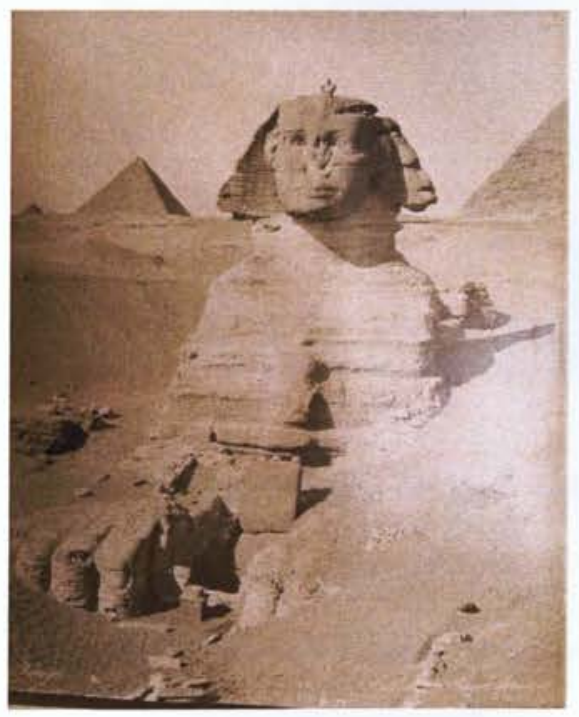

Fig. 39

Zangaki brothers (Georgios Zangaki, ca.1845-ca. 1895, Constantinos Zangaki, ca.1845-1916)

Sphynx decouvert[sic], after 1885

Albumen print

No.796, BnF: 40492256, EO-487-BOITE FOL B 


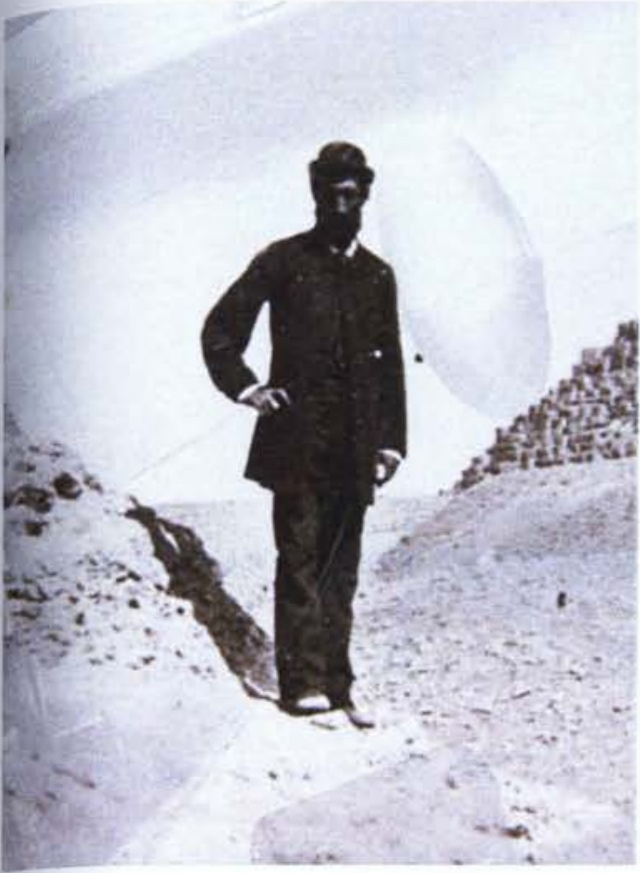

Fig. 40

Zangaki brothers (Georgios Zangaki, ca.1845-ca.1895, Constantinos Zangaki, ca.1845-1916)

Le Sphynx et Pyramide, detail of one of the Zangaki brothers, between 1865 and 1885

Albumen print

$22.7 \times 27.7 \mathrm{~cm}$.

No.106, AGO: 2008/121.47

(See Fig.36 for the whole image)

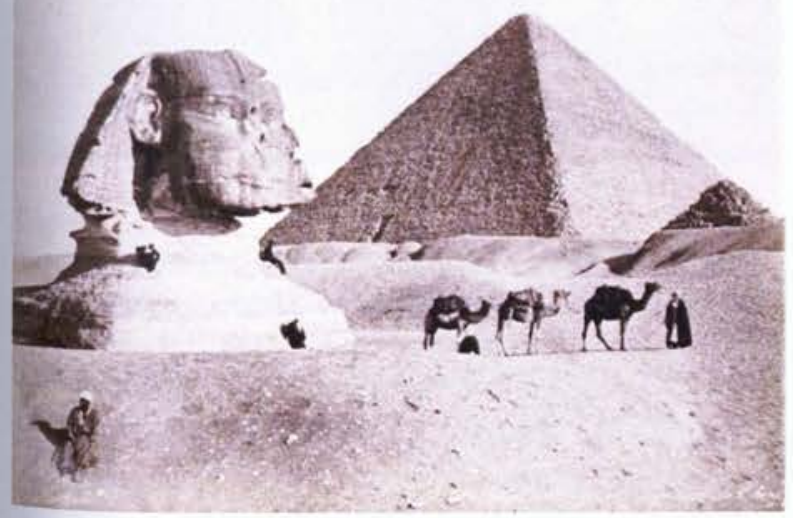

Fig. 41

Zangaki brothers (Georgios Zangaki, ca.1845-ca.1895. Constantinos Zangaki, ca.1845-1916)

Sphynx et la grand Pyramide de Cheope, between 1865 and 1885

Albumen print

No.80, CCA: PH1986:0566

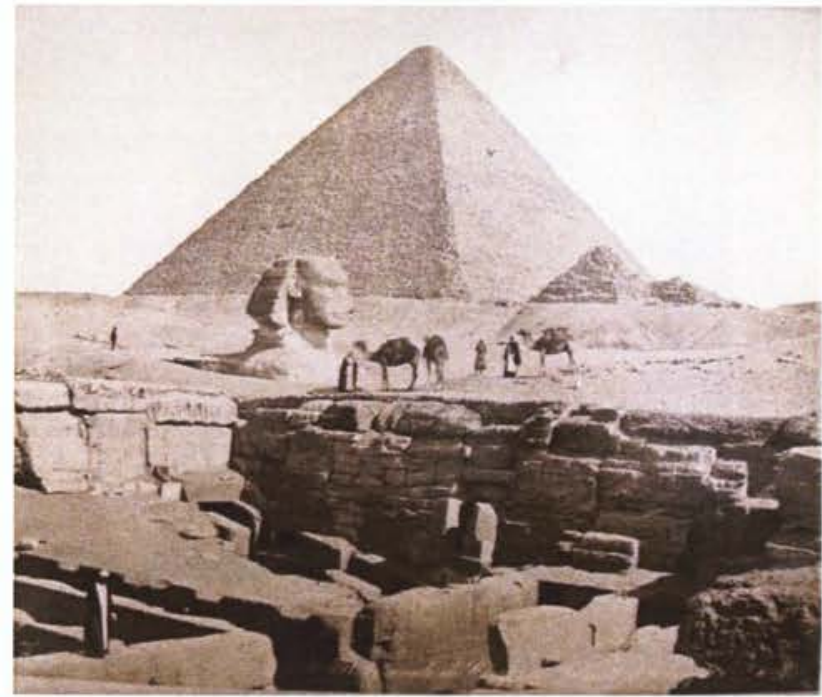

Fig. 42

Zangaki brothers (Georgios Zangaki, ca.1845-ca.1895, Constantinos Zangaki, ca.1845-1916)

Pyramide de Cheops le Sphynx et le temple de Choffs, between 1865 and 1885

Albumen print

No.391, BnF: 40589991 , IFN-7702173

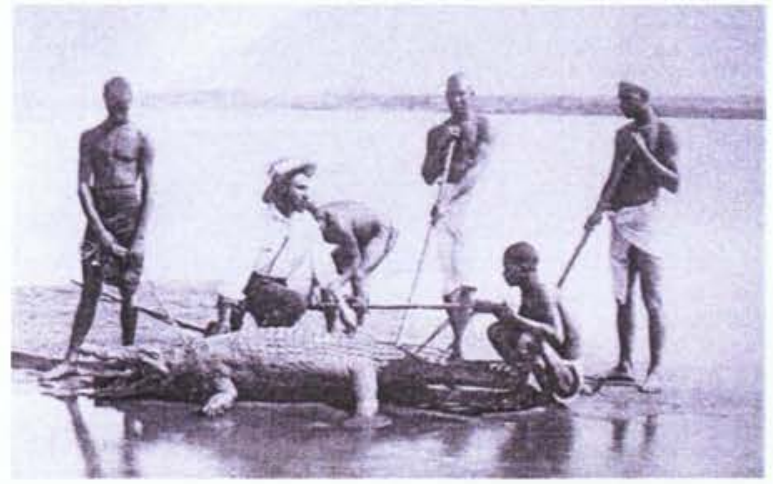

Fig. 43

Zangaki brothers (Georgios Zangaki, ca.1845-ca.1895, Constantinos Zangaki, ca.1845-1916)

[Nubians and the crocodile], ca.1880

Albumen print

Unknown number, in Xanthakis 2005 article (62), (Christian Adam Coll.) 


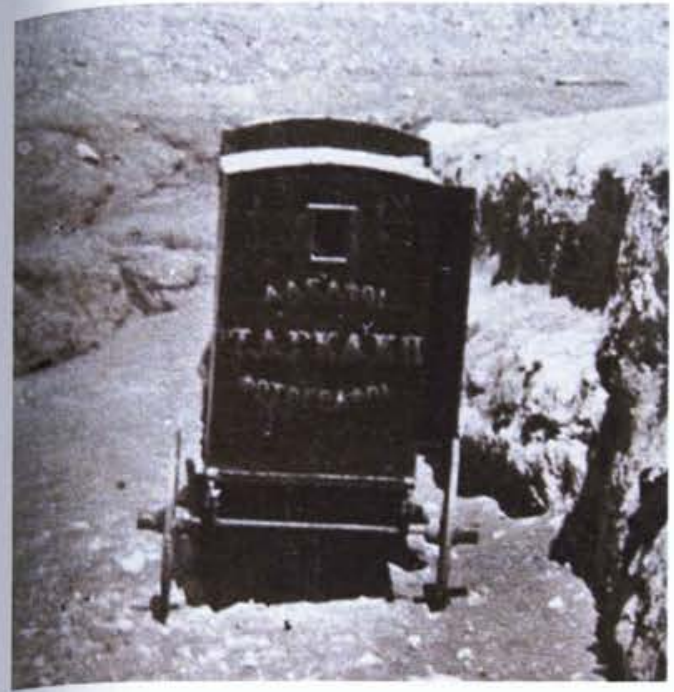

Fig. 44

Zangaki brothers (Georgios Zangaki, ca.1845-ca.1895, Constantinos Zangaki, ca.1845-1916)

Le Sphynx et Pyramide, detail of the portable darkroom, between 1865 and 1885

Albumen print

$22.7 \times 27.7 \mathrm{~cm}$

No.106, AGO: 2008/121.47

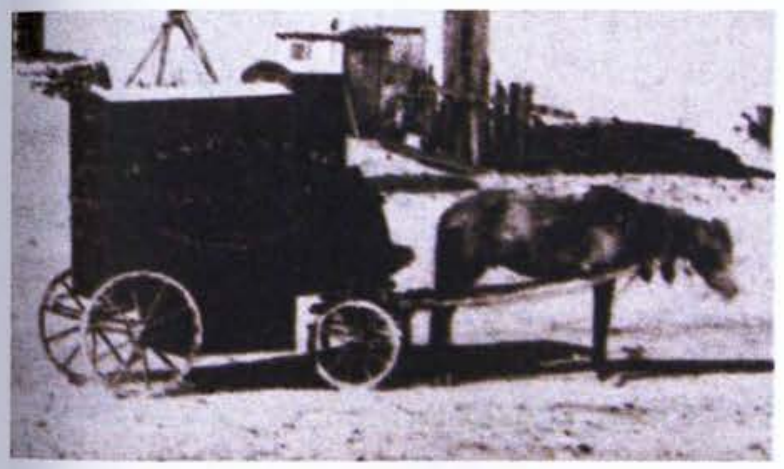

Fig. 45

Zangaki brothers (Georgios Zangaki, ca.1845-ca.1895,

Constantinos Zangaki, ca.1845-1916)

[Lake Mariut], detail of the portable darkroom, ca.1880

Albumen print

Unknown number, Osman 1997 (4)

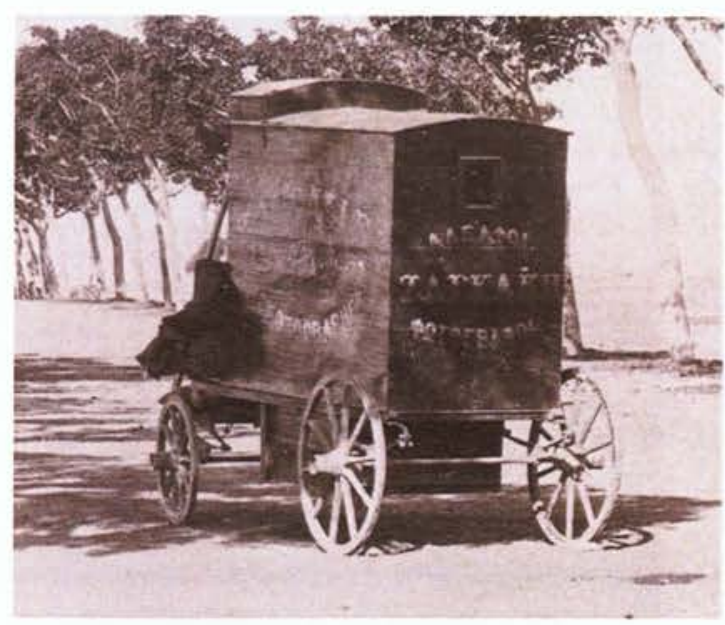

Fig. 46

Zangaki brothers (Georgios Zangaki, ca.1845-ca.1895, Constantinos Zangaki, ca.1845-1916)

Avemue des pyramides Cairo, detail of the portable darkroom, ca. 1880

Albumen print

No.156, Nicholas Warner Coll.

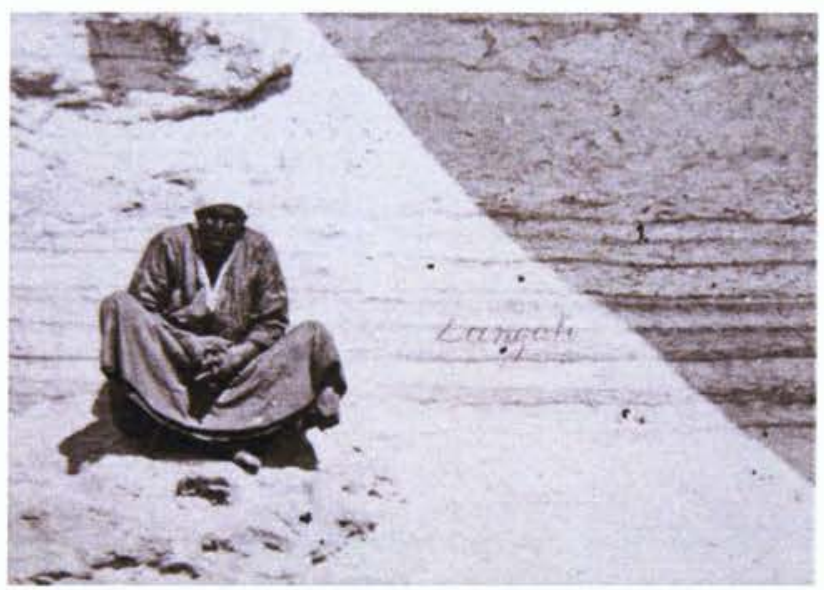

Fig. 47

Zangaki brothers (Georgios Zangaki, ca.1845-ca.1895, Constantinos Zangaki, ca.1845-1916)

Le Sphynx et Pyramide, detail of the inscription on the Sphinx, between 1865 and 1885

Albumen print

$22.7 \times 27.7 \mathrm{~cm}$

No.106. AGO: 2008/121.47 


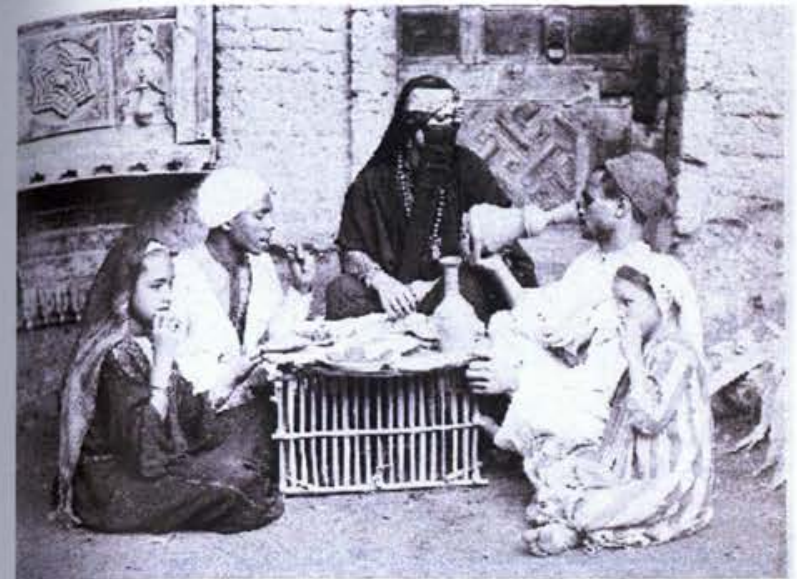

\section{Fig. 48}

Zangaki brothers (Georgios Zangaki, ca.1845-ca.1895, Constantinos Zangaki, ca.1845-1916)

Diner Arabe, ca. 1880

Albumen print

No.598, UCL:381-95

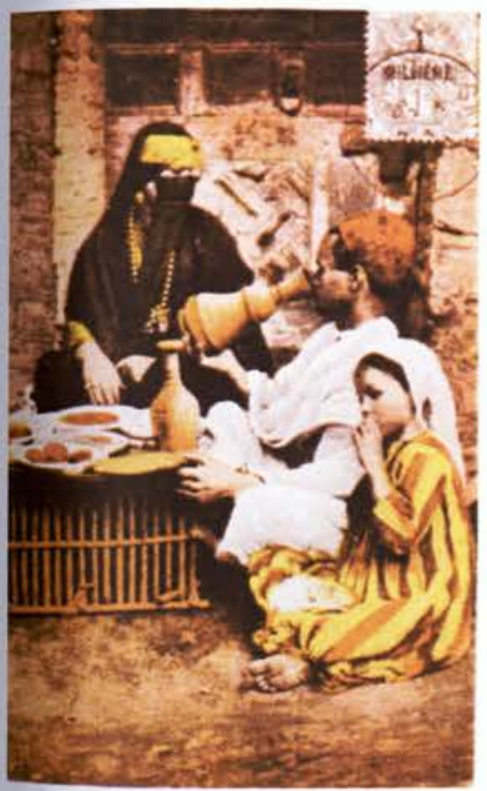

Fig. 49

Zangaki brothers (Georgios Zangaki, ca.1845-ca.1895, Constantinos Zangaki, ca.1845-1916)

[Egypt, Arab Family], ca. 1900

Posteard publisher - C. Andreopoulos, Vegnios \& Zachos Postcard

Approximately $15 \times 10.5 \mathrm{~cm}$., in Osman 1997 (134)

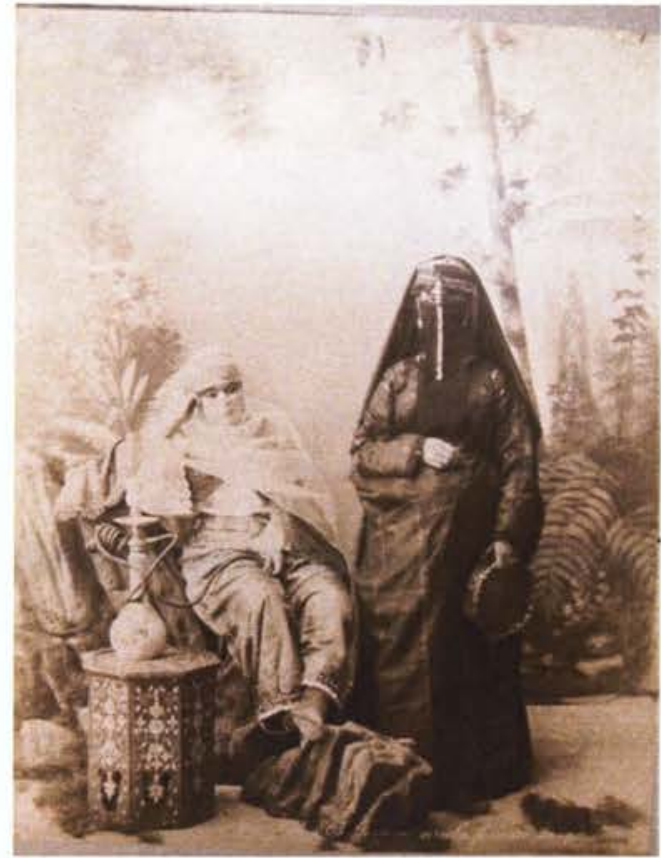

Fig. 50

Zangaki brothers (Georgios Zangaki, ca.1845-ca.1895, Constantinos Zangaki, ca.1845-1916)

Femme arabe femme turque, ca. 1880

Albumen print

No.803, BnF: 40492256, EO-487-BOITE FOL B

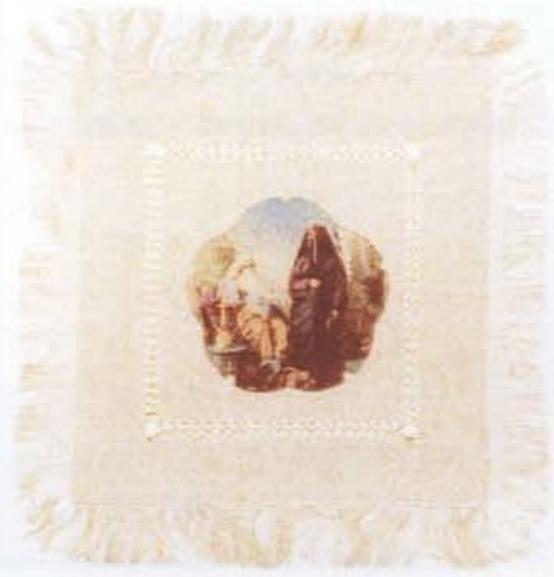

Fig. 51

Zangaki brothers (Georgios Zangaki, ca.1845-ca. 1895 , Constantinos Zangaki, ca. 1845-1916)

[Two Middle Eastern Women], ca.1900

Coloured photograph transferred either to a handkerchief or a silk place mat, in Jacobson 2007 (195) 


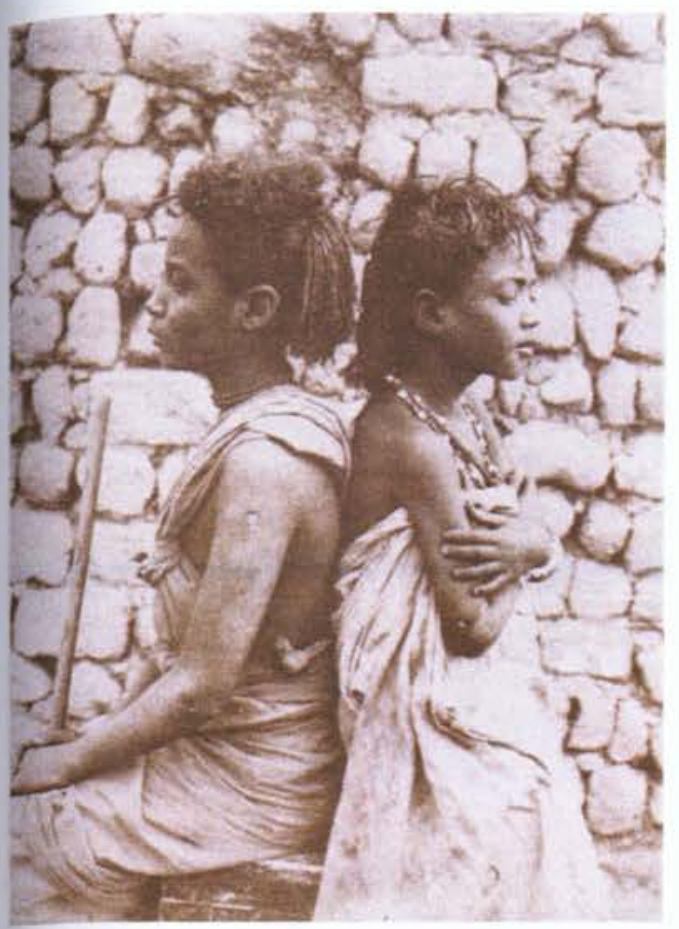

Fig. 52

Zangaki brothers (Georgios Zangaki, ca.1845-ca.1895, Constantinos Zangaki, ca.1845-1916)

[Two Sudanese Women], ca.1880

Albumen print

No.582, in Osman 1997 (92)

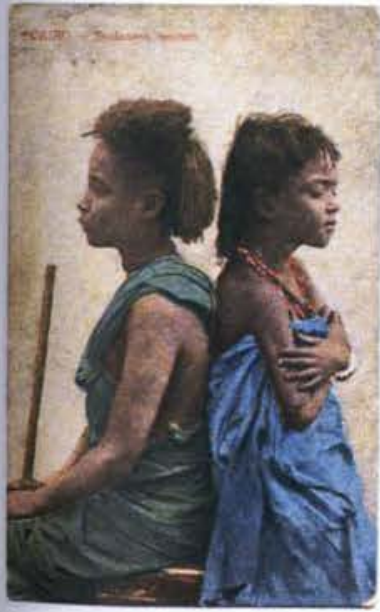

\section{Fig. 53}

Zangaki brothers (Georgios Zangaki, ca.1845-ca.1895, Constantinos Zangaki, ca.1845-1916)

[Two Sudanese Women], ca.1900

Postcard publisher - Edit, The Cairo Postcard Trust

Coloured postcard

Approximately $15 \times 10.5 \mathrm{~cm}$.

Ebay (full website description can be found on footnote \#89)

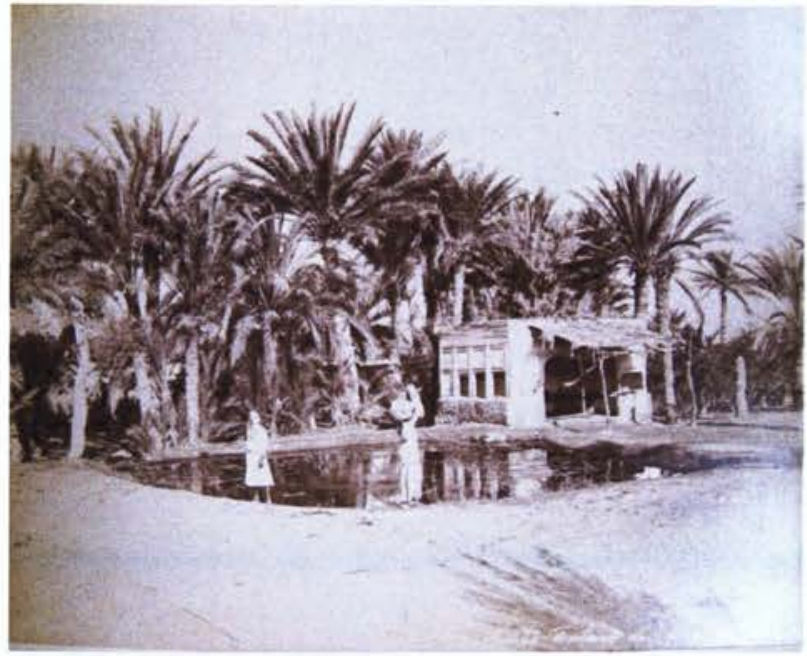

Fig. 54

Zangaki brothers (Georgios Zangaki, ca.1845-ca.1895, Constantinos Zangaki, ca.1845-1916)

Fontaine de Moise el Suez, ca.1880

Albumen print

No.237, Marta Braun Coll.

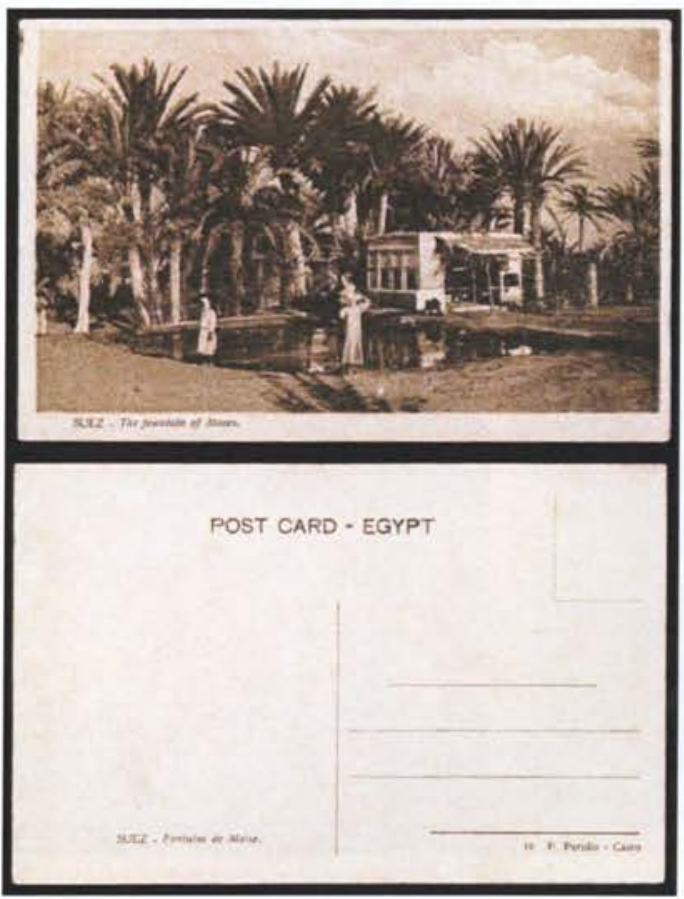

\section{Fig.55}

Zangaki brothers (Georgios Zangaki, ca.1845-ca.1895, Constantinos Zangaki, ca.1845-1916)

Suez - Fontaine de Moise, ca.1900

Postcard publisher - P. Peridis (Cairo, No.16)

Postcard

Approximately $10.5 \times 15 \mathrm{~cm}$.

Ebay (full website description can be found on footnote $\# 90$ ) 


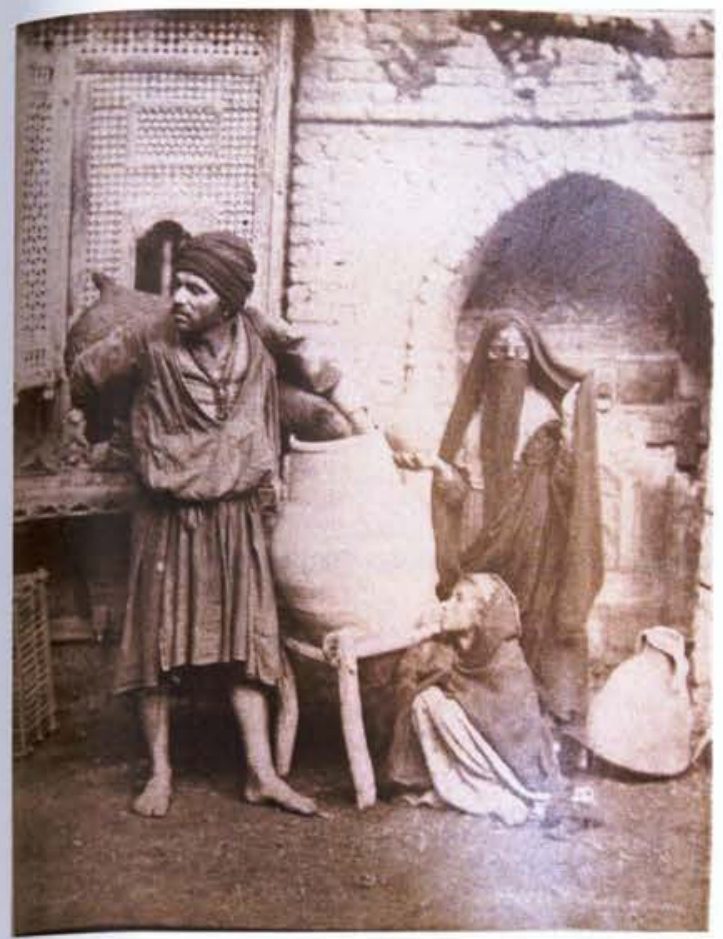

Fig. 56

Zangaki brothers (Georgios Zangaki, ca.1845-ca.1895, Constantinos Zangaki, ca.1845-1916)

Porteur d'eau, ca. 1880

Albumen print

No.573, BnF: 40492256, EO-487-BOITE FOL B

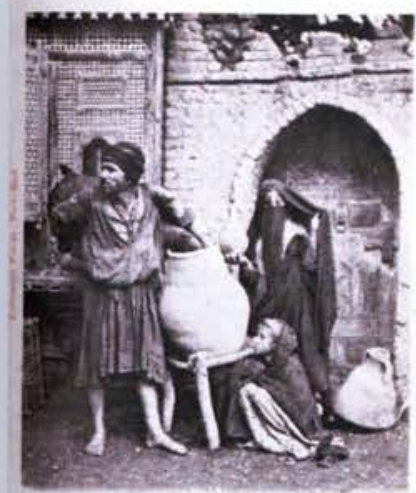

Fig. 57

Zangaki brothers (Georgios Zangaki, ca.1845-ca.1895, Constantinos Zangaki, ca.1845-1916)

Porteur d'eau, ca. 1900

Postcard publisher - Ephtimios Frères Port-Said

Postcard

Approximately $15 \times 10.5 \mathrm{~cm}$.

Ebay (full website description can be found on footnote \#91)

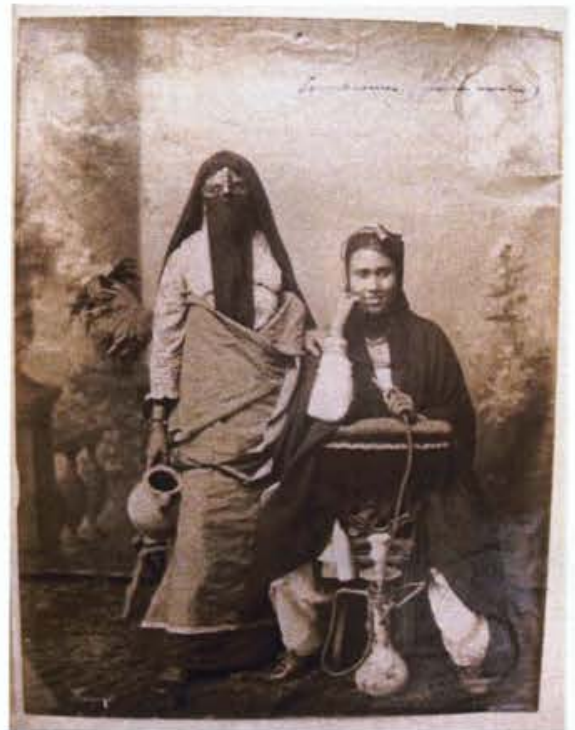

Fig. 58

Zangaki brothers (Georgios Zangaki, ca.1845-ca.1895, Constantinos Zangaki, ca.1845-1916)

[Egpytiennes], ca.1880

Albumen print

Unnumbered, BnF:40492256, EO-487-BOITE FOL B

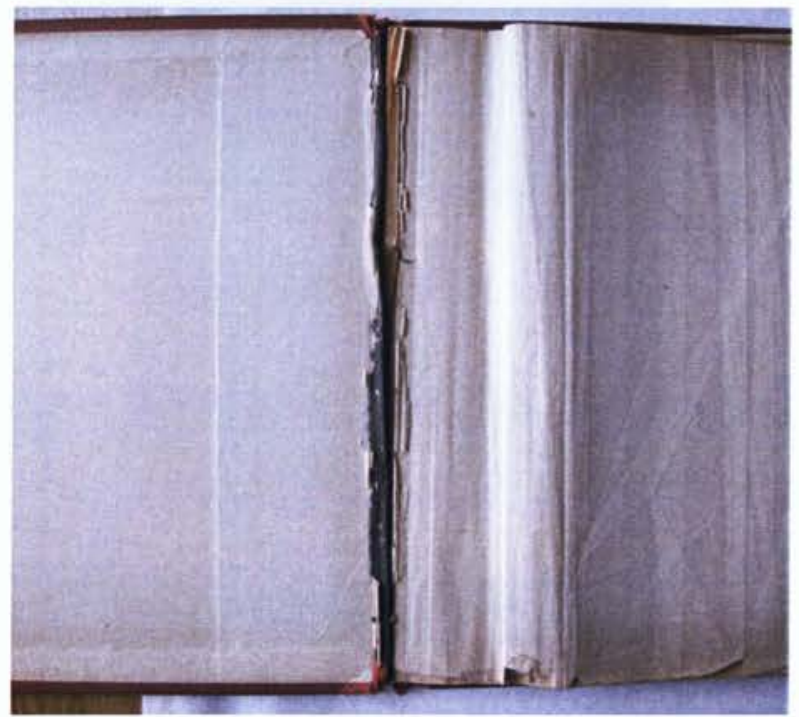

Fig. 59

Views of Egvpt, detail of weakened binding AGO: 2008/121 


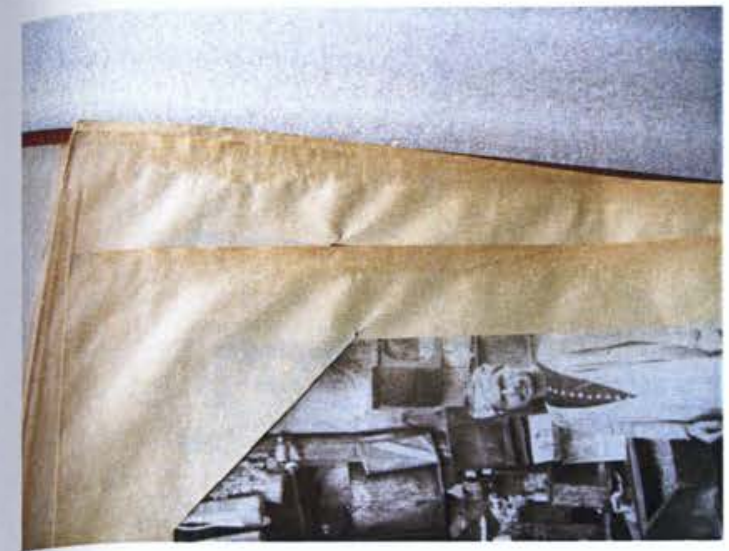

Fig. 60

Views of Egypt, detail of acidic pages

AGO: 2008/121

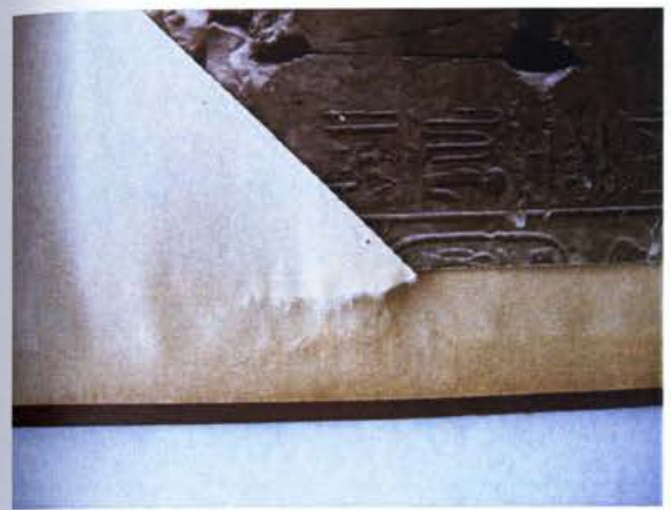

Fig. 61

Views of Egypt, example of a tear AGO: 2008/121

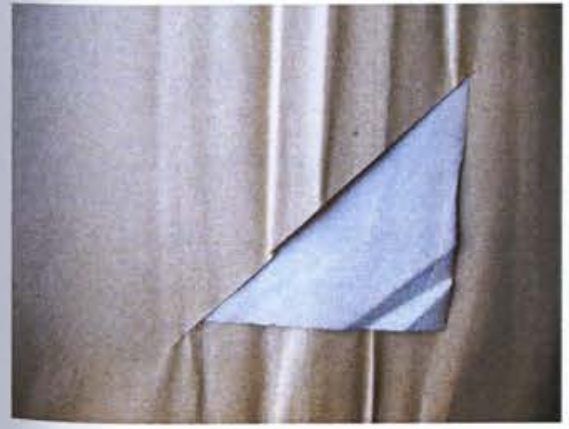

Fig. 62

Views of Egypt, example of a crease AGO: $2008 / 121$

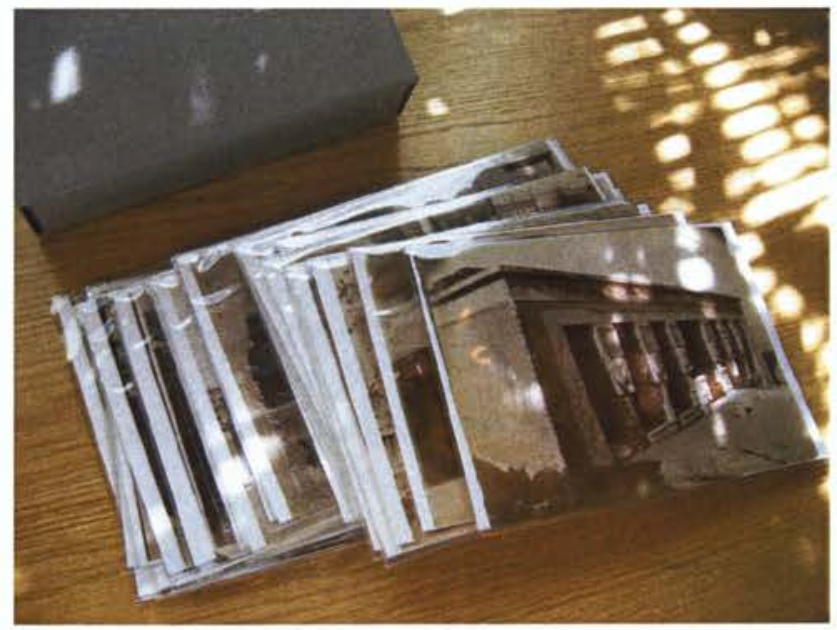

Fig. 63

Completed Views of Egypt prints in mylar sleeves with the Hollinger box

AGO: 2008/121

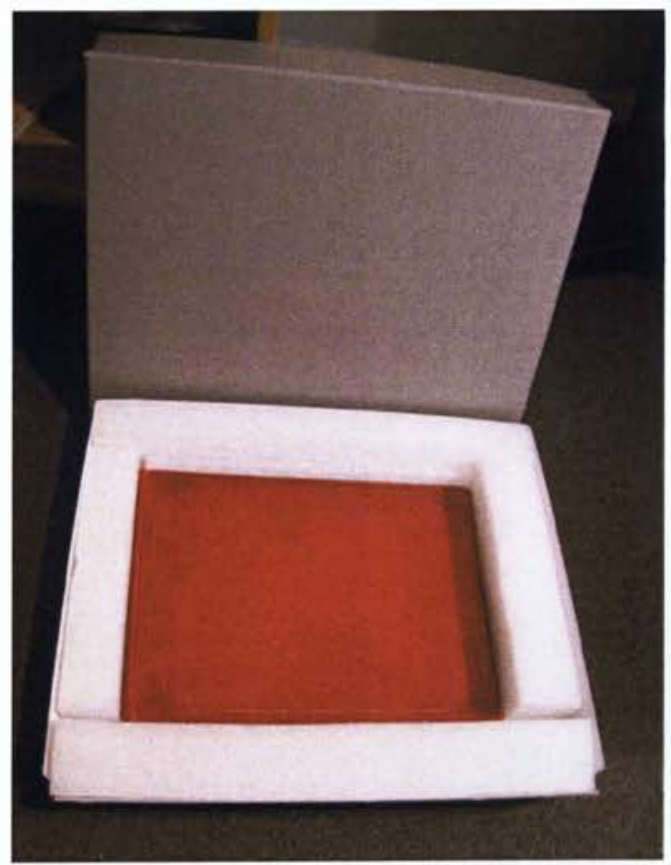

Fig. 64

Views of Egypt empty album shell stored in the Hollinger box

AGO: 2008/121 
APPENDIX B:

CATALOGUE OF THE VIEWS OF EGYPT ALBUM 


\section{CATALOGUING METHODOLOGY}

I documented each print by the following fields in Microsoft Excel: AGO ID, Creator, Negative Number (Neg. No), Title, Date, Medium, Size $(\mathrm{cm})$, Condition, Notes.

The "AGO ID" field refers to the identification number of the print. The album's accession number is $2008 / 121$. The number for each individual print is a sub-number, such as from $2008 / 121.1$ to $2008 / 121.47$. These records will display the catalogue information for that individual print in the AGO database.

The "Creator" field lists the name associated with each print, as taken from the signature found on the bottom-left corner of the prints. If there is no signature, I have entered "Unknown," "Zangaki [attributed to]," and "Zangaki or Peridis [attributed to]" in the spreadsheet.

The "Neg. No." field is the number written on the bottom-right corner of the print. It is normally after the "N" letter and before the title of the location or subject. This negative number is the number that the Zangaki brothers, Peridis and Georgiladakis gave to that specific negative or print. If there is no negative number on the print, I have entered "Unnumbered."

The "Title" field is entered from the location or subject name on the print. This can be found on the bottom right corner after the negative number. I have chosen to transcribe the title as it appears on the print. If no location name was found, a title in square brackets "[The Road of Sphinx]" was entered. If the title was illegible, "[...]Karnac" was entered. If there is a spelling mistake, "[sic]" is used.

The "Date" field is entered according to the photographers' active period. The dates are unknown for all the prints; thus, a circa "ca." is assigned to give the best 
available information about the print. Circa dates are usually represented with a range of ten years - five years on either side of the given date. The date can vary according to historical information that the print provides, such as the progression of the clearing sand from the breast of the Sphinx.

The "Medium" field lists the medium of the prints. Although all the prints are albumen prints, this will ensure that this information will be available to curators who are only looking at individual prints rather than any secondary material.

The "Size (cm)" field is entered according to height and width in centimeters. For photographs with uneven edges, I entered the longest side.

Entered in the "Condition" field are short forms indicating various conditions, such as crease, tear, bend, fold, discoloration, specs, stain, and so on. Specific letters were used to describe the location of the damage: Location Key: $\mathrm{R}=$ right, $\mathrm{L}=$ left, $\mathrm{T}=\mathrm{top}, \mathrm{B}=$ bottom, $\mathrm{C}=$ corner, $\mathrm{E}=$ edge, $\mathrm{M}=$ middle.

The "Notes" field refers to any other relevant information that does not fit in any of the above fields. If "Peridis $e$ " was entered as the photographer for the print, but Georgiladakis' name had also been written on the print though later erased, this would be entered in the notes as, "Georgiladakis' signature was erased." Both "Condition" and "Notes" have not been included in Appendix B due to lack of space, although they will be included in the version that the AGO receives. 


\begin{tabular}{|c|c|c|c|c|c|c|c|}
\hline & A & $B$ & C & $\mathrm{D}$ & $E$ & $\bar{F}$ & G \\
\hline & AGO ID & Creator & Neg. No. & Title & Date & Medium & Size $(\mathrm{cm})$ \\
\hline & $2008 / 121.1$ & Zangaki & 900 & Denderah temple Athor & ca.1880 & Albumen print & $22 \times 28.2$ \\
\hline & $2008 / 121.2$ & Zangaki [attributed to] & 11 & [Two Middle Eastern Women] & ca. 1880 & Albumen print & $21.7 \times 28.2$ \\
\hline 4 & $2008 / 121.3$ & Zangaki & 895 & Abydos Ramses II et Petit & ca. 1880 & Albumen print & $22 \times 27.7$ \\
\hline 5 & $2008 / 121.4$ & Zangaki & 880 & Abydos Interieur[sic] & ca. 1880 & Albumen print & $21.8 \times 28.4$ \\
\hline 6 & $2008 / 121.5$ & Zangaki [attributed to] & Unnumbered & [Thebes colosses de Memnon] & ca. 1880 & Albumen print & $21.7 \times 27.8$ \\
\hline 7 & $2008 / 121.6$ & Zangaki & 643 & Arabe prenant son caffe[sic] & ca. 1880 & Albumen print & $21.8 \times 28.1$ \\
\hline 8 & $2008 / 121.7$ & Zangaki & 934 & Thebes Interieur[sic] de tombe roi No. 6 & ca. 1880 & Albumen print & $22.3 \times 28.4$ \\
\hline 9 & $2008 / 121.8$ & Zangaki & 608 & Epicerie[sic] arabe & ca. 1880 & Albumen print & $22.1 \times 28.2$ \\
\hline 10 & $2008 / 121.9$ & Zangaki & 926 & $\begin{array}{c}\text { Statue de Ramses III [...see] du } \\
\text { Ramesseum Thebes }\end{array}$ & ca. 1880 & Albumen print & $21.4 \times 28.2$ \\
\hline 11 & $2008 / 121.10$ & Peridis e & 1026 & Grand temple Luxor & ca. 1890 & Albumen print & $21.6 \times 27.9$ \\
\hline 12 & $2008 / 121.11$ & Peridis e & 1031 & Columns at Luxor & ca.1890 & Albumen print & $21.5 \times 27.8$ \\
\hline 13 & $2008 / 121.12$ & Zangaki & 975 & Louxor ensemble des colonnades & ca. 1880 & Albumen print & $21.8 \times 27.3$ \\
\hline 14 & $2008 / 121.13$ & Zangaki & 1025 & Edfou Vue generale[sic] du temple & ca.1880 & Albumen print & $22 \times 28.3$ \\
\hline 15 & $2008 / 121.14$ & Peridis e Georgiladakis & 1030 & Ramseon Luxor & ca.1890 & Albumen print & $21.9 \times 28.2$ \\
\hline 16 & $2008 / 121.15$ & Peridis e Georgiladakis & 1171 & Luxor Bazaar & ca. 1890 & Albumen print & $21.6 \times 27.8$ \\
\hline 17 & $2008 / 121.16$ & Peridis & 1024 & Ramses at Luxor & ca.1890 & Albumen print & $21.6 \times 27.9$ \\
\hline 18 & $2008 / 121.17$ & Zangaki & 953 & Vue generalle[sic] de Louqur[sic] & ca. 1880 & Albumen print & $21.8 \times 28.3$ \\
\hline 19 & $2008 / 121.18$ & $\begin{array}{l}\text { Zangaki or Peridis } \\
\text { [attributed to] }\end{array}$ & Unnumbered & [The road of Sphinx] & ca. 1880 & Albumen print & $21.5 \times 27.9$ \\
\hline 20 & 2008/ 121.19 & Peridis e & 1062 & Ramses at Karnac & ca. 1890 & Albumen print & $21.4 \times 27.8$ \\
\hline 21 & $2008 / 121.20$ & Peridis e & 1073 & Kamac Grand Column & ca. 1890 & Albumen print & $21.9 \times 27.7$ \\
\hline 22 & $2008 / 121.21$ & Peridis e Georgiladakis & 1060 & [...]Karnac & ca. 1890 & Albumen print & $21.8 \times 27.9$ \\
\hline 23 & $2008 / 121.22$ & Peridis & 1066 & Grand entrance[sic] avenue of Sphync & ca. 1890 & Albumen print & $21.6 \times 27.5$ \\
\hline 24 & $2008 / 121.23$ & Peridis e & 1040 & Arch Ptelomeo Karnac & ca.1890 & Albumen print & $21.5 \times 28$ \\
\hline 25 & $2008 / 121.24$ & $\begin{array}{l}\text { Zangaki or Peridis } \\
\text { [attributed to] }\end{array}$ & Unnumbered & [The road of Sphinx] & ca. 1880 & Albumen print & $21.7 \times 27.8$ \\
\hline 26 & $2008 / 121.25$ & Peridis e & 1046 & Front veiu[sic] of Karnac & ca.1890 & Albumen print & $21.6 \times 27.7$ \\
\hline 27 & $2008 / 121.26$ & Zangaki & 1032 & Edfou Interieur[sic] & ca. 1880 & Albumen print & $21.7 \times 28.2$ \\
\hline 28 & $2008 / 121.27$ & Zangaki & 1024 & Edfou Interieur[sic] du temple & ca. 1880 & Albumen print & $21.5 \times 28.3$ \\
\hline 29 & $2008 / 121.28$ & Zangaki & 1026 & Edfou Pyione du temple de Horus & ca. 1880 & Albumen print & $21.9 \times 28.2$ \\
\hline 30 & $2008 / 121.29$ & Zangaki & Unnumbered & [Le Sphinx] & ca. 1880 & Albumen print & $21.9 \times 27.7$ \\
\hline 31 & $2008 / 121.30$ & Zangaki & 1037 & Edfou Bas-relief du temple de Horus & ca. 1880 & Albumen print & $21.5 \times 27.7$ \\
\hline 32 & $2008 / 121.31$ & Zangaki & 1043 & Bas-relief du temple de Horous & ca.1880 & Albumen print & $21.7 \times 27.6$ \\
\hline 33 & $2008 / 121.32$ & $\begin{array}{c}\text { Pascal Sébah [attributed } \\
\text { to] }\end{array}$ & 58 & [Turkish Woman] & ca.1880 & Albumen print & $21.7 \times 28$ \\
\hline 34 & $2008 / 121.33$ & Zangaki & 1082 & Phylae Le Kiosque d'Isis & ca. 1880 & Albumen print & $22 \times 28$ \\
\hline
\end{tabular}


The "Views of Egypt" Album, Photography Collection of the Art Gallery of Ontario 2008/ 121

\begin{tabular}{|c|c|c|c|c|c|c|c|}
\hline & A & B & $\mathrm{C}$ & D & $\bar{E}$ & $F$ & G \\
\hline & $2008 / 121.34$ & Zangaki & 1056 & Assouan premier caracte[sic] & ca. 1880 & Albumen print & $21.5 \times 27.5$ \\
\hline 36 & $2008 / 121.35$ & Zangaki & 1009 & $\begin{array}{c}\text { Karnak Grand te[n]le avec Obelisque[sic] } \\
\text { de Touthmes }\end{array}$ & ca. 1880 & Albumen print & $22 \times 27.8$ \\
\hline 37 & $2008 / 121.36$ & Peridis e & 1175 & De [dri Toune] of Egypte & ca.1890 & Albumen print & $21.5 \times 27.8$ \\
\hline 38 & $2008 / 121.37$ & Zangaki & 1077 & $\begin{array}{l}\text { Philae Vue d'ensemble de colonnade } \\
\text { temple d'isis }\end{array}$ & ca. 1880 & Albumen print & $21.9 \times 28.1$ \\
\hline 39 & $2008 / 121.38$ & Zangaki & 493 & Palmieres[sic] vis a vis[sic] du Kasr-el-Nil & ca. 1880 & Albumen print & $21.8 \times 28$ \\
\hline 40 & $2008 / 121.39$ & Zangaki & 1003 & $\begin{array}{l}\text { Karnak Ruine obelisque[sic] de } \\
\text { Touthmes ler et de sa fille Hatasu }\end{array}$ & ca. 1880 & Albumen print & $21.5 \times 28$ \\
\hline 41 & $2008 / 121.40$ & Zangaki & 521 & Soldat Abyssin a[sic] Dogali & ca. 1880 & Albumen print & $21.4 \times 27.7$ \\
\hline 42 & $2008 / 121.41$ & Zangaki & 630 & Chadoufs de la Houte[sic] Egypte[sic] & ca. 1880 & Albumen print & $21.4 \times 27.7$ \\
\hline 43 & $2008 / 121.42$ & Zangaki & 457 & Pyramide de Sakkara & ca. 1880 & Albumen print & $21.5 \times 28.1$ \\
\hline 44 & $2008 / 121.43$ & Zangaki & 901 & Denderah Entrée d'antinaos & ca. 1880 & Albumen print & $21.5 \times 28.1$ \\
\hline 45 & $2008 / 121.44$ & Zangaki [attributed to] & 920 & Thebes Memorium de Ramses III & ca. 1880 & Albumen print & $21.8 \times 27.3$ \\
\hline 46 & $2008 / 121.45$ & Peridis e & 1029 & Columns Luxor & ca. 1890 & Albumen print & $21.6 \times 28$ \\
\hline 47 & $2008 / 121.46$ & Zangaki & 946 & Thebes tombe de roi No.9 & ca. 1880 & Albumen print & $21.5 \times 28$ \\
\hline 48 & $2008 / 121.47$ & Zangaki & 106 & Le Sphynx et Pyramide & ca.1870 & Albumen print & $22.7 \times 27.7$ \\
\hline
\end{tabular}




\section{APPENDIX C: \\ LIST OF NEGATIVE NUMBERS \\ FROM THE ZANGAKI BROTHERS' PRINTS}




\section{ABBREVIATIONS IN THE NEGATIVE LIST}

AGO

AIF

AUB

AUC

$\mathrm{BnF}$

CCA

CCP

GEH

Gr. Inst.

GRI

LOC

Marta Braun Coll.

MET

NYPL

UCL
Art Gallery of Ontario, Toronto, Ontario, Canada

Arab Image Foundation, Beirut, Lebanon

American University of Beirut, Jafet Library, Beirut, Lebanon

Photographic and Cinema Collections in Rare Books and Special Collections Library, American University of Cairo, Cairo, Egypt

Département des 'Estampes et de la Photographie, Bibliothèque nationale de France, Paris, France

Centre Canadien d'Architecture, Montreal, Quebec, Canada

Center for Creative Photography, Tuscon, Arizona, U.S.A

George Eastman House International Museum of Photography and Film, Rochester, New York, U.S.A

Griffith Institute, Oxford, England

Getty Research Institute, Los Angeles, U.S.A

Library of Congress, Washington, U.S.A

Marta Braun's Private Collection, Toronto, Canada

Metropolitan Museum of Art, New York, New York, U.S.A

New York Public Library, New York, New York, U.S.A

University of Chicago Library, Chicago, U.S.A 


\section{CATALOGUING METHODOLOGY}

I decided to keep the list small and only include the fields that were necessary for each print: Zangaki Negative Number (Neg. No.), Title, Repository \& ID and Notes. Some of these fields are established already in the section of cataloguing methodology of the Views of Egypt album. The differences follow as such:

If the negative number on the print was illegible, I have entered it as "illeg;" if there was no number on the print, I have entered it as "Unnumbered;" if the image was found online and the number was illegible because it is online, I have entered "Unknown;" if I could not figure out a number in the negative number, I have put for example "1057?"; and, lastly, if I could not distinguish between, say, a 530 or a 630 , I have written " 530 or $630 . "$

The "Repository \& ID" is entered based on where the print is currently located. I attempted to use as many prints as possible from online catalogues of institutions in addition to the examination of original prints. There are many Zangaki prints worldwide, and it is important to keep this list open to any source. The short form of the institution was used, such as "AGO," and, if the print has an access number, it was written after the name. Example: AGO, 2008/121.35.

If the print's photographer was entered as "Zangaki," although a faint " $\mathrm{H}$. Arnoux" signature is visible, this would be entered in the "Notes" field as "H. Arnoux's signature was possibly erased. This field has not been included in Appendix C due to lack of space. 


\begin{tabular}{|c|c|c|c|}
\hline & A & B & $\mathrm{C}$ \\
\hline 1 & $\begin{array}{l}\text { Zangaki } \\
\text { Neg. No. }\end{array}$ & Title & Repository \& ID \\
\hline 2 & 1 & Balarata passant I'El-Guirs & $\begin{array}{l}\text { Harvard University Library, EgAl.001, } \\
\text { AKP021 }\end{array}$ \\
\hline 3 & 3 & Port Said[sic] & GRI, 2008_r_3_4479 \\
\hline 4 & 5 & [...] Port Saîd & GRI, 2008_r_3_3254 \\
\hline 5 & 8 & Quai de Port-Said[sic] & CCP, T247/S14B, 78:111:007 \\
\hline 6 & 9 & $\begin{array}{c}\text { Bateaux arretes[sic] a[sic] Port Said a[sic] cause } \\
\text { de la Drague }\end{array}$ & BnF, 40492256, EO-487-BOITE FOL B \\
\hline 7 & 9 & Vue Generale[sic] de Port-Said[sic] & UCL, $176-85$ \\
\hline 8 & 10 & Vue générale de Port-Said[sic] & CCP, T247/S14B, 78:111:006 \\
\hline 9 & 11 & [Two Middle Eastern Women] & AGO, 2008/ 121.2 \\
\hline 10 & 11 & Pyramide de Chefren Caire & GRI. 2008_r_3_3277 \\
\hline 11 & 14 & Bateaux arrestés[sic] à port [...] & GRI, 2008_r_3_3247 \\
\hline 12 & 14 & Bateaux arrêtés à Port-Said[....][sic] & CCP, T247/S14B, 78:111:008 \\
\hline 13 & 14 & Bateaux arretes[sic] a[sic] Port S[...]de Drague & The University of Tennessee \\
\hline 14 & 18 & Untitled & AUC, 19th Century photographs \\
\hline 15 & 19 & Port de Port-Said[sic] & Ebay, eyall-com \\
\hline 16 & 24 & Ensemble de Port Saìd & GRI, 2008_r_3_3268 \\
\hline 17 & 27 & Ensemble de PortSaid et le [...] & CCA, PH1980:1049 \\
\hline 18 & 29 & Port Said village arabe & $\mathrm{BnF}, 40589991$, IFN-7702173 \\
\hline 19 & 30 & illeg & GEH, 1986:0310:0002 \\
\hline 20 & 30 & [lbn Tulun Mosque] & $\begin{array}{l}\text { Fine Arts Library, Harvard College Library, } \\
\text { Tulu } 5 b 1\end{array}$ \\
\hline 21 & 31 & Suez maree[sic] haute & $\mathrm{BnF}, 40589991, \mathrm{IFN}-7702173$ \\
\hline 22 & 31 & Suez Maree[sic] haute & BnF, 40492256, EO-487-BOITE FOL B \\
\hline 23 & 34 & Rue de com[erce a][sic] Port Said & $\mathrm{BnF}, 40492256$, EO-487-BOITE FOL B \\
\hline 24 & 36 & Entrée du [canal a ] Port-Said[sic] & $\mathrm{BnF}, 40492256, \mathrm{EO}-487-\mathrm{BOITE}$ FOL B \\
\hline 25 & 37 & Vinh long[sic] arivee[sic] de canal & BnF, 40492256, EO-487-BOITE FOL B \\
\hline 26 & 72 & Place des consul a[sic] Alexandria & BnF, 40492256, EO-487-BOITE FOL B \\
\hline 27 & 73 & A $[\ldots]$ Offrande de $[\ldots]$ & NYPL, 87079 \\
\hline 28 & 77 & Suez, vue d'ensemble & Marta Braun Coll. \\
\hline 29 & 78 & Le Muezzu Caire & Marta Braun Coll. \\
\hline 30 & 80 & Sphynx et la grand Pyramide de Cheope & CCA, PH1986:0566 \\
\hline 31 & 85 & Groupe des dattiées à Fontaine de Moisé & NYPL, 81455 \\
\hline 32 & 86 & Station de canal & BnF, 40492256, EO-487-BOITE FOL B \\
\hline 33 & 87 & Le Caire chanteuses fellahs & BnF, 40589982, IFN- 7702164 \\
\hline 34 & 89 & Entrée du canal à Port Saìd & GRI, 2008_r_3_3246 \\
\hline 35 & 92 & Vilage arabe d'pyramide Cairo & AUC, 19th Century photographs \\
\hline
\end{tabular}




\begin{tabular}{|c|c|c|c|}
\hline & A & $B$ & $\mathrm{C}$ \\
\hline 36 & 104 & Sphynx et la grande pyramide & NYPL, 88428 \\
\hline 37 & 106 & Le Sphynx et Pyramide & AGO, 2008/ 121.47 \\
\hline 38 & 115 & $\begin{array}{c}\text { Mosquee[sic] de Mohammed Ali prise de } \\
\text { Mokatam }\end{array}$ & UCL, 339-93 \\
\hline 39 & 117 & Port de Port-Said[sic] & BnF, 40589991, IFN- 7702173 \\
\hline 40 & 118 & Bords du Nil & Marta Braun Coll. \\
\hline 41 & 118 & Esnef Colonade[sic] sohle riqin[...] & BnF, 40492256, EO-487-BOITE FOL B \\
\hline 42 & 121 & illeg & BnF, 40588367, MFILM SG W- 115 \\
\hline 43 & 127 & Untitied & Marta Braun Coll. \\
\hline 44 & 134 & Femme arabe avec son enfant & GRI, 2008_r_3_3294 \\
\hline 45 & 138 & Port Teuffich Suez & AUC, 19th Century photographs \\
\hline 46 & 142 & Karnak Salle hypostyle colonnes [...] & Gr. Inst. 6262 \\
\hline 47 & 149 & Arab Sheik & UCL, 311-92 \\
\hline 48 & 151 & Place a[sic] Port-Said[sic] & BnF, 40589991 , IFN- 7702173 \\
\hline 49 & 152 & Bain des[...] & GEH, 2001:1522:0005 \\
\hline 50 & $152 ?$ & Le Caire porte de la citadelle & BnF, 40589982, IFN- 7702164 \\
\hline 51 & 153 & Partie del Caire el Mosquee[sic] Hassan & GEH, 1981:2125:0014 \\
\hline 52 & $156 ?$ & Pyramide de Sakkarah & $\mathrm{BnF}, 40589982, \mathrm{IFN}-7702164$ \\
\hline 53 & 156 & Avenue des pyramides Caire & Nicholas Warner Coll. \\
\hline 54 & 159 & Dahabieh et port de Kasr-el[...] & NYPL, 81452 \\
\hline 55 & 161 & $\begin{array}{l}\text { [Camels in front of Sphinx and pyramids, } \\
\text { photographer's van to left] }\end{array}$ & GRI, 2008_r_3_4150 \\
\hline 56 & 161 & $\begin{array}{l}\text { Le Sphinx et les pyramides, Chephren et } \\
\text { Cheops }\end{array}$ & $\mathrm{BnF}, 40589982$, IFN- 7702164 \\
\hline 57 & 161 & Le Spyhnx et Pyramide & BnF, 40492256, EO-487-BOITE FOL B \\
\hline 58 & 163 & Groupe des dattiers a[sic] Fontaine de Moise & $\mathrm{BnF}, 40589991$, IFN-7702173 \\
\hline 59 & 165 & La grande Sphynx & Gr. Inst. Somers Clarke MSS. 11.2 \\
\hline 60 & 170 & Egypte[sic] bords du Nil & BnF, 40589982, IFN- 7702164 \\
\hline 61 & 172 & Au bord du Nil & $\mathrm{BnF}, 40589982, \mathrm{IFN}-7702164$ \\
\hline 62 & 173 & Le Sphinx et la grande pyramide de Cheops & BnF, 40589982, IFN- 7702164 \\
\hline 63 & 173 & Vue generale[sic] d'Alexandrie & $\begin{array}{l}\text { Bassenge Kunst- Und Buchauktionen, LOT } \\
4278\end{array}$ \\
\hline 64 & $176 ?$ & Le Caire et les bords du Nil & $\mathrm{BnF}, 40589982$, IFN-7702164 \\
\hline 65 & 180 & Mosquee[sic] de Mohamet Ali Caire & GEH, 1981:2125:0004 \\
\hline 66 & 180 & Le Caire mosquee[sic] de Mehemet -Ali & $\mathrm{BnF}, 40589982$, IFN-7702164 \\
\hline 67 & 180 & Mosquee[sic] de Mohamed Ali [...] & $\begin{array}{l}\text { Bassenge Kunst- Und Buchauktionen, LOT } \\
4278\end{array}$ \\
\hline 68 & 181 & Chalet du Kedive Lac Timsah & GRI, 2008_r_3_3251 \\
\hline 69 & 181 & Vue general[sic] d'Alexandrie prise du phare & NYPL, 85378 \\
\hline 0 & 182 & Port d'Alexandrie & NYPL, 85379 \\
\hline
\end{tabular}




\begin{tabular}{|c|c|c|c|}
\hline & A & $B$ & $\mathrm{C}$ \\
\hline 71 & 184 & Shepheard Hotel Caire & GRI, 2008_r_3_3273 \\
\hline 72 & 184 & Jetes[sic] de Porte & Marta Braun Coll. \\
\hline 73 & 188 & Village arabe et pyramide Caire. & UCL, 304-91 \\
\hline 74 & 189 & Obélisque d'Heliopolis & Gr. Inst. 453B \\
\hline 75 & 192 & Panorama du Caire pris de la citadelle & GEH, 1981:2125:0013 \\
\hline 76 & 196 & Promenade de $[\ldots]$ Caire & GEH, 2001:1522:0012 \\
\hline 77 & 196 & Sphinx decouvert[sic] & $\mathrm{BnF}, 40589982$, IFN-7702164 \\
\hline 78 & 196 & Sphynx decouvert[sic] & $\mathrm{BnF}, 40492256, \mathrm{EO}-487-\mathrm{BOITE}$ FOL B \\
\hline 79 & 198 & Courbe de chalouf & CCP, T247/S14B, 78:111:014 \\
\hline 80 & 201 & Mosquee[sic] de Mohamet Ali & GEH, 1981:2126:0007 \\
\hline 81 & 202 & Vue generale[sic] des tombeaux Memlukes & UCL, $178-86$ \\
\hline 82 & $203 ?$ & Le Caire palais de Choubrah & $\mathrm{BnF}, 40589982, \mathrm{IFN}-7702164$ \\
\hline 83 & $2 ? 4$ & Groupe de chameaux et pyramides & $\mathrm{BnF}, 40589982$, IFN- 7702164 \\
\hline 84 & 205 & Palais de Choubrah Caire & $\mathrm{BnF}, 40589991, \mathrm{IFN}-7702173$ \\
\hline 85 & 206 & Le Sphynx Caire & GEH, 2001:1522:0015 \\
\hline 86 & 210 & Arrosage des jardins au bord du Nil & BnF, 40589982, IFN- 7702164 \\
\hline 87 & 210 & Alexandrie Colonne de Pompee & NYPL, 85380 \\
\hline 88 & 214 & Dahabie sur le Nil Egypte[sic] & The University of Tennessee \\
\hline 89 & 218 & Les catacombes d'Alexandrie & NYPL, 85381 \\
\hline 90 & 220 & Piquage du blé en Egypte & AUB, Jafet Library, $1 / 763$ \\
\hline 91 & 224 & Vue de Barage de Nil & UCL, $179-86$ \\
\hline 92 & 230 & Rue Kormar a[sic] Suez & Marta Braun Coll. \\
\hline 93 & 231 & Fontain de Moise à Suez & Ebay, photobazaar \\
\hline 94 & 233 & Palmiers $[\ldots]$ & GEH, 1983:1317:0002 \\
\hline 95 & 235 & Vue generale[sic] de la citadelle & NYPL, 85358 \\
\hline 96 & 235 & Fontain de Moise à Suez & CCA, PH1980:1048 \\
\hline 97 & $236 ?$ & Alexandrie palmiers & $\mathrm{BnF}, 40589982$, IFN-7702164 \\
\hline 98 & 236 & Vue du Caire et Mosquee de Mohamed Aly & $\begin{array}{c}\text { Fine Arts Library, Harvard College Library, } \\
\text { Muh 1d } \\
\end{array}$ \\
\hline 99 & 237 & Fontaine de Moise el Suez & Marta Braun Coll. \\
\hline 100 & 237 & Vue du Caire et mosque[sic] Sultan Hassan & NYPL, 85359 \\
\hline 101 & 239 & Caire Vue Panoramique & GEH, 1983:1317:0001 \\
\hline 102 & 239 & Vue panorimique[sic] & UCL, 328-92 \\
\hline 103 & 240 & Phare Alexandria Louqor[sic] & AUC, 19th Century photographs \\
\hline 104 & 241 & Panorama du Vieux Caire et pyramide & $\begin{array}{c}\text { Fine Arts Library, Harvard College Library, } \\
\text { unknown }\end{array}$ \\
\hline 105 & 243 & Caire Vue[...] & UCL, $165-85$ \\
\hline
\end{tabular}




\begin{tabular}{|c|c|c|c|}
\hline & A & B & $\mathrm{C}$ \\
\hline 106 & 245 & Quai d'Alexandrie & CCP, T247/S14B, 78:111:013 \\
\hline 107 & 245 & Femme arabe portant enfant & $\mathrm{BnF}, 40589991, \mathrm{IFN}-7702173$ \\
\hline 108 & 252 & Marchand des tapis & GEH, 1978:1297:0023 \\
\hline 109 & 254 & $\begin{array}{l}\text { Mosquee[sic] de Mohamed Ali fontain des } \\
\text { ablutions }\end{array}$ & UCL, 348-93 \\
\hline 110 & 262 & Jardin de l'Egypte[sic] & GEH, 1978:1297:0031 \\
\hline 11] & 263 & Chech arab & NYPL, 88429 \\
\hline 112 & 263 & Chech arabe & $\mathrm{BnF}, 40589991, \mathrm{IFN}-7702173$ \\
\hline 113 & $269 ?$ & [Femmes egyptiennes[sic] et enfant] & $\mathrm{BnF}, 40589982$, IFN-7702164 \\
\hline 114 & 269 & [Two women and child] & GRI, 2008_r_3_3275 \\
\hline 115 & 281 & $\begin{array}{l}\text { Int. grande porte de la Mosquee[sic] Azhar, } \\
\text { Caire }\end{array}$ & $\mathrm{UCL}, 333-92$ \\
\hline 116 & 284 & $\begin{array}{l}\text { Cour de la Mosquee[sic] El Azhar reunion des } \\
\text { theologiens[sic] Caire }\end{array}$ & UCL, 330-92 \\
\hline 117 & 285 & Mosquee[sic] Touloun Caire & UCL, 331-92 \\
\hline 118 & 298 & Caire, vue prise de mosquée & GRI, 2008_r_3_3270 \\
\hline 119 & 298 & Caire Vue Panoramique & BnF, 40492256, EO-487-BOITE FOL B \\
\hline 120 & 300 & Phylae Vue generale[sic] & Gr. Inst. 792 \\
\hline 121 & 300 & Vue generale[sic] du Caire & Gr. Inst. 4082 \\
\hline 122 & 302 & Citadelle et cimetiere[sic] arabe Cairo & GRI, 2008_r_3_3272 \\
\hline 123 & 307 & Village arabe et eitadelle[sic] & Marta Braun Coll. \\
\hline 124 & 307 & Rue de vieux Caire & UCL, $180-86$ \\
\hline 125 & 307 & Colonade du grand temple de Louqsor[sic] & Gr. Inst. 187 \\
\hline 126 & 312 & Palais d'Abdin au Caire & $\mathrm{BnF}, 40589991, \mathrm{IFN}-7702173$ \\
\hline 127 & 313 & Mosquée Mehemet Ali fontaine des ablutions & GRI, 2008_r_3_3271 \\
\hline 128 & 314 & Interieur[sic] de la mosquée Mehemet-Aly Caire & Gr. Inst. 4086 \\
\hline 129 & 315 & Interieur[sic] de la mosqueé[sic] de Mohemet Ali & GRI, 2008_r_3_3472 \\
\hline 130 & 316 & $\begin{array}{c}\text { Interieur[sic] de la mosqueé[sic] Mehmet Aly } \\
\text { Caire }\end{array}$ & GRI, 2008_r_3_3346 \\
\hline 131 & 316 & Moulet el Neby Fete[sic] arabe Caire & Marta Braun Coll. \\
\hline 132 & 317 & Mosquee[sic] Sultan Hassan & UCL, $167-85$ \\
\hline 133 & 319 & Porte de la Mosquée Hassan & Musée d'Orsay, PHO 1996529 \\
\hline 134 & 320 & Interieur[sic] de la Mosquee[sic] Hassan & UCL, $171-85$ \\
\hline 135 & 320 & Intérieur de la Mosquée Hassan & Musée d'Orsay, PHO 1996528 \\
\hline 136 & 321 & Grand bazar[sic] a[sic] Kasr-el-Nil Caire & NYPL, 85361 \\
\hline 137 & 321 & Grand bazar[sic] au Kasr el Nil Caire & UCL, 377-95 \\
\hline 138 & 326 & Maison arabe et Moucharabie & UCL, 375-95 \\
\hline 139 & 329 & illeg & BnF, 40588367, MFILM SG W-115 \\
\hline 140 & 333 & Tombeaux des Khalifes & UCL, $166-85$ \\
\hline
\end{tabular}




\begin{tabular}{|c|c|c|c|}
\hline & A & B & C \\
\hline 141 & 334 & [Abyssinian man] & GRI, 2008_r_3_3290 \\
\hline 142 & 336 & [Two Abyssinian boys] & GRI, 2008_r_3_3289 \\
\hline 143 & 340 & $\begin{array}{l}\text { Groupe des minarets et mosquee[sic] d'El- } \\
\text { Azhar }\end{array}$ & UCL, $168-85$ \\
\hline 144 & 343 & Saqquieh & Gr. Inst. 4103 \\
\hline 145 & 346 & Leis due[sic] Caire & Marta Braun Coll. \\
\hline 146 & 348 & Jeune fille arabe & BnF, 40492256, EO-487-BOITE FOL B \\
\hline 147 & 357 & Vue generalle[sic] des Pyramides & Gr. Inst. 292B \\
\hline 148 & 360 & Cour interieure[sic] de la caserne de Kasr-el-Nil & GRI, 2008_r_3_3266 \\
\hline 149 & 360 & Palmiers sur les bords du Nil & GEH, 1986:0309:0086 \\
\hline 150 & 361 & Entree[sic] du Pont de Kasr-el-Nil & $\begin{array}{l}\text { Bassenge Kunst- Und Buchauktionen, LOT } \\
4278\end{array}$ \\
\hline 151 & 365 & Le Sphynx et des Pyramides & BnF, 40492256, EO-487-BOITE FOL B \\
\hline 152 & 368 & Fete[sic] arabe, Caire & GRI, 2008_r_3_3279 \\
\hline 153 & 369 & Arrivée du Mahmel Caire & AUB, Jafet Library, $1 / 551$ \\
\hline 154 & 370 & $\begin{array}{l}\text { Le Caire cour interieure[sic] de la caserne de } \\
\text { Kasr-en-Nil }\end{array}$ & $\mathrm{BnF}, 40589982$, IFN- 7702164 \\
\hline 155 & 371 & (Caire) Ville Arab[sic] & GEH, 1981:2126:0004 \\
\hline 156 & 372 & Rue du vieux Caire & BnF, 40589991, IFN- 7702173 \\
\hline 157 & 373 & Bord du Nil et Palmiers & GEH, 1983:1345:0001 \\
\hline 158 & 373 & $\begin{array}{c}\text { Caire, Combeause des Mameluks vue } \\
\text { generale[sic] }\end{array}$ & Marta Braun Coll. \\
\hline 159 & 375 & illeg & BnF, 40588367, MFILM SG W-115 \\
\hline 160 & 376 & Vue des trois Pyramides & GEH, 2001:1522:0016 \\
\hline 161 & 378 & Rue de vieux Caire & GRI, 2008_r_3_3286 \\
\hline 162 & 378 & illeg & BnF, 40588367, MFILM SG W-115 \\
\hline 163 & 381 & Vue generale[sic] des $[\ldots]$ & $\mathrm{BnF}, 40588367$, MFILM SG W-115 \\
\hline 164 & 381 & Vue generale[sic] des pyramides & NYPL, 85365 \\
\hline 165 & 381 & $\begin{array}{l}\text { Rue de la Mosquee[sic] Touloun. } \\
\text { Mouchurab[ieh] }\end{array}$ & UCL, $170-85$ \\
\hline 166 & 381 & $\begin{array}{l}\text { Rue de la Mosquee[sic] Touloun. } \\
\text { Mouchurab[ieh] }\end{array}$ & UCL, 332-92 \\
\hline 167 & 382 & Maison arabe et moucharabie & CCP, T247/S14B, 78:111:001 \\
\hline 168 & 385 & Palmieres[sic] sur les bords du Nil & GEH, 1978:1297:0022 \\
\hline 169 & 386 & Sphynx armackes[sic] & BnF, 40492256, EO-487-BOITE FOL B \\
\hline 170 & 388 & La retoure des Pyramides & BnF, 40492256, EO-487-BOITE FOL B \\
\hline 171 & 390 & illeg & $\mathrm{BnF}, 40588367, \mathrm{MFILM}$ SG W-115 \\
\hline 172 & 390 & Grand bazar[sic] au Kasr-al-Nil Caire & CCP, T247/S14B, 78:111:010 \\
\hline 173 & 390 & Caire) Minaret et Muesin & UCL, 99-85 \\
\hline 174 & 390 & Grand bazar[sic] au Kasr el Nil Cairo & LOC, LOT 13549-15, no. 1 [P\&P] \\
\hline 175 & 391 & illeg & $\mathrm{BnF}, 40588367, \mathrm{MFILM}$ SG W-115 \\
\hline
\end{tabular}




\begin{tabular}{|c|c|c|c|}
\hline & A & $B$ & C \\
\hline 176 & 391 & $\begin{array}{c}\text { Pyramide de Cheops, le Sphinx et le temple de } \\
\text { Chaffa }\end{array}$ & $\mathrm{BnF}, 40589991, \mathrm{IFN}-7702173$ \\
\hline 177 & 391 & $\begin{array}{c}\text { Pyramide de Cheops le Sphynx et le temple de } \\
\text { Choffs }\end{array}$ & BnF, 40492256, EO-487-BOITE FOL B \\
\hline 178 & 392 & $\begin{array}{c}\begin{array}{c}\text { Pyramide de Cheops le Sphinx et le temple de } \\
\text { Chefre }\end{array} \\
\end{array}$ & NYPL, 85364 \\
\hline 179 & 394 & Caire New Hotel & NYPL, 85360 \\
\hline 180 & 396 & (Caire) interieur[sic] de la Mosquee[sic] Hambro & GEH, 1981:2125:0009 \\
\hline 181 & 396 & Caire Interieur[sic] de la Mosquee[sic] Hambro & UCL, 378-93 \\
\hline 182 & $407 ?$ & Bazar[sic] au villafe[sic] de boulaq & $\mathrm{BnF}, 40589982$, IFN-7702164 \\
\hline 183 & 409 & Phabee[sic] de Memphis a[sic] & AUC, 19th Century photographs \\
\hline 184 & 409 & Statue de Memphis a Sakkara & NYPL, 85366 \\
\hline 185 & 410 & Loaretoure[sic] des Pyramide & BnF, 40492256, EO-487-BOITE FOL B \\
\hline 186 & 410 & Obelisque[sic] d'Heliopolis & NYPL, 85368 \\
\hline 187 & 410 & La retoure des Pyramides & The University of Tennessee \\
\hline 188 & 411 & L'arbre de la Vierge & NYPL, 85367 \\
\hline 189 & 411 & Voiliers arabe dans le Nil & $\begin{array}{l}\text { The Oriental Institute of University of } \\
\text { Chicago, lost egypt catalog }\end{array}$ \\
\hline 190 & $417 ?$ & Chameaux de mariage arabe & BnF, 40590054, FN-7702237 \\
\hline 191 & 417 & Passage au port de Kasr el Nil & NYPL, 85363 \\
\hline 192 & 426 & Groupe de chameux et pyramides & Gr. Inst. 6283 \\
\hline 193 & 427 & Pyramide et [...] & GRI, 2008_r_3_3278 \\
\hline 194 & 428 & Bord du Nil et Palmiers & BnF, 40492256, EO-487-BOITE FOL B \\
\hline 195 & 430 & Nil de Boulak Caire & Gr. Inst. 4096 \\
\hline 196 & 431 & Dahabieh et pont de Kasr-el-ch & Marta Braun Coll. \\
\hline 197 & 435 & Ascension de la grande Pyramide & The University of Tennessee \\
\hline 198 & 436 & Vue generale[sic] des Pyramides & UCL, $162-85$ \\
\hline 199 & 438 & Inondation du Nil & NYPL, 85377 \\
\hline 200 & $446 ?$ & sphynx et pyramide de Cheops & Gr. Inst. 6284 \\
\hline 201 & 449 & Le Sphinx & $\mathrm{BnF}, 40590054, \mathrm{FN}-7702237$ \\
\hline 202 & $450 ?$ & illeg & BnF, 40588367, MFILM SG W-115 \\
\hline 203 & 450 & Vue generale[sic] de Barage du Nil & Marta Braun Coll. \\
\hline 204 & 450 & Le Sphynx & Gr. Inst. 4089 \\
\hline 205 & 451 & Port Saìd, village arabe & GRI, 2008_r_3_3252 \\
\hline 206 & 452 & Spyhnx decouvert[sic] & Collection of François Lepage, Paris \\
\hline 207 & 453 & Spyhnx Armachis & Collection of François Lepage, Paris \\
\hline 208 & 455 & Phare de Port Said & GRI, 2008_r_3_3256 \\
\hline 209 & 455 & Phare de Port Said ( Entrée du Canal de Suez) & BnF, 40492256, EO-487-BOITE FOL B \\
\hline 210 & 456 & Rue du comerce a[sic] Port-Said & GEH, 1986:0310:0005 \\
\hline
\end{tabular}




\begin{tabular}{|c|c|c|c|}
\hline & A & $B$ & C \\
\hline 211 & 457 & Pyramide de Sakkara & AGO, 2008/ 121.42 \\
\hline 212 & 458 & Rue du comerce a[sic] Port-Said & GEH, 2001:1522:0007 \\
\hline 213 & 458 & Chameatu[sic] du [...] & BnF, 40492256, EO-487-BOITE FOL B \\
\hline 214 & 460 & Femme felah Egyptienne[sic] & Ebay, Pump Park Vintage Photography \\
\hline 215 & 461 & Drague a[sic] longue couloire & GEH, 1986:0310:0003 \\
\hline 216 & 461 & Drague a'longue[sic] couloire & BnF, 40492256, EO-487-BOITE FOL B \\
\hline 217 & 462 & Obelisque[sic] de Heliopolis & UCL, $102-85$ \\
\hline 218 & 464 & illeg & BnF, 40588367, MFILM SG W-115 \\
\hline 219 & 470 & Passage au pont de Kasr el Nil & GRI, 2008_r_3_3250 \\
\hline 220 & 471 & Voiliers arabe dans le Nil & Gr. Inst. 4097 \\
\hline 221 & 472 & $E[\ldots]$ de marriage arabe & Marta Braun Coll. \\
\hline 222 & 472 & [...] De mariage arabe & BnF, 40492256, EO-487-BOITE FOL B \\
\hline 223 & 472 & [...]mariage arabe & NYPL, 85362 \\
\hline 224 & 474 & Bourricot du Caire & BnF, 40589991 , IFN- 7702173 \\
\hline 225 & 481 & Ferme d'Autruches & AUB, Jafet Library, $1 / 778$ \\
\hline 226 & 482 & Laboureur fellah & AUB, Jafet Library, $1 / 760$ \\
\hline 227 & 483 & Piquage du ble[sic] 'au Egypt[...][sic] & BnF, 40492256, EO-487-BOITE FOL B \\
\hline 228 & 485 or 585 & [...] de la mosque[sic] de Kail-bey & Marta Braun Coll. \\
\hline 229 & 486 & Sakkieh dans la Haute Egypte[sic] & NYPL, 85376 \\
\hline 230 & 493 & Palmieres[sic] vis a vis[sic] du Kasr-el-Nil & AGO, 2008/ 121.38 \\
\hline 231 & 494 & Caire Ziker Fete[sic] arabe & UCL, 346-93 \\
\hline 232 & $496 ?$ & Deux soeurs [bicharines] & BnF, 40589991, IFN-7702173 \\
\hline 233 & 498 & Caire Inondation aux Pyramides & Gr. Inst. 292A \\
\hline 234 & $504 ?$ & Alexandrie porte du palais de Ras-el-tin-co & $\mathrm{BnF}, 40589982$, IFN-7702164 \\
\hline 235 & 504 & Chameau de desert[sic] & GRI, 2008_r_3_3291 \\
\hline 236 & 505 & illeg & Ebay, eyall-com \\
\hline 237 & 507 & Chameau de desert[sic] & GRI, 2008_r_3_3296 \\
\hline 238 & 511 & Groupe des bédouins et chameaux & CCP, T247/S14B, 78:111:018 \\
\hline 239 & 516 & Caire fantaisie d'un mariage & CCP, T247/S14B, 78:111:016 \\
\hline 240 & 517 & Chameaux de mariage arabe & CCP, T247/S14B, 78:111:015 \\
\hline 241 & 517 & Bicharins $[\ldots]$ & $\mathrm{BnF}, 40492256$, EO-487-BOITE FOL B \\
\hline 242 & 520 & Deuse[sic] femmes d'Abisinie & BnF, 40492256, EO-487-BOITE FOL B \\
\hline 243 & 521 & Soldat Abyssin a[sic] Dogali & AGO, 2008/ 121.40 \\
\hline 244 & 527 & Nubie Famille bicharine & AUB, Jafet Library, $1 / 738$ \\
\hline 45] & 531 & Chameau avec son petit & AUB, Jafet Library, $1 / 770$ \\
\hline
\end{tabular}




\begin{tabular}{|c|c|c|c|}
\hline & A & $B$ & C \\
\hline 246 & 532 & Des femines[sic] arabes portant de l'eau du Nil & BnF, 40492256, EO-487-BOITE FOL B \\
\hline 247 & 534 & La chasse du crocodil au bord du Nil & GRI, 2008_r_3_4636 \\
\hline 248 & 534 & La Chasse du crocodil au bord du Nil & BnF, 40492256, EO-487-BOITE FOL B \\
\hline 249 & 537 & Groupe des crocodiles & GRI, 2008_r_3_3285 \\
\hline 250 & 540 & Saqqieh Egyptiene[sic] & GEH, 2000:0814:0015 \\
\hline 251 & 540 & Saqqiah Egyptienne[sic] & The Iznik Gallery Berlin \\
\hline 252 & 540 & Saqqieh egyptiene[sic] & Gr. Inst. 4095 \\
\hline 253 & 540 & Saqqieh egyptiene[sic] & Ebay, photobazaar \\
\hline 254 & 545 & Ecole[sic] arabe & NYPL, 85374 \\
\hline 255 & 545 & Ecole[sic] arabe & UCL, 379-95 \\
\hline 256 & 546 & Saqqiah & The Iznik Gallery Berlin \\
\hline 257 & 547 & des femmes arabes portant de l'eau du[...] & BnF, 40492256, EO-487-BOITE FOL B \\
\hline 258 & 547 & Sakihe tournée par une chameau & The University of Tennessee \\
\hline 259 & 553 & Coifeur[sic] arabe & BnF, 40492256, EO-487-BOITE FOL B \\
\hline 260 & 555 & Le[sic] someille profond[sic] & NYPL, 85375 \\
\hline 261 & 559 & [Women on horse-drawn cart] & NYPL, 85373 \\
\hline 262 & 560 & Chalouf a[sic] la Aute[sic] Egypte[sic] & Gr. Inst. 6263 \\
\hline 263 & 561 & {$[\ldots]$ du Caire } & BnF, 40492256, EO-487-BOITE FOL B \\
\hline 264 & 562 & Invitation d'un marriage arab & NYPL, 88431 \\
\hline 265 & 562 & Inn[...] tion d'un mariage arabe & BnF, 40492256, EO-487-BOITE FOL B \\
\hline 266 & 562 & Charmeur des serpents & NYPL, 88437 \\
\hline 267 & 564 & Bords du Nil porteurs de'eau & $\mathrm{BnF}, 40589982$, IFN- 7702164 \\
\hline 268 & 564 & Porteurs d'au[...] & BnF, 40492256, EO-487-BOITE FOL B \\
\hline 269 & $564 ?$ & Caire chameau avec un musicien sur le dos & BnF, 40590054, FN-7702237 \\
\hline 270 & $57 ?$ & Groupe de femmes & $\mathrm{BnF}, 40590054, \mathrm{FN}-7702237$ \\
\hline 271 & 565 & Remouleur arabe et son client & BnF, 40589982 , IFN- 7702164 \\
\hline 272 & 571 & Derviche $[\ldots]$ & Ebay, photobazaar \\
\hline 273 & 572 & Marchand d'arghissous & UCL, 312-92 \\
\hline 274 & 572 & Assouan des jardins [...] du Nil & Ebay, eyall-com \\
\hline 275 & 573 & Porteur d'eau & $\mathrm{BnF}, 40492256$, EO-487-BOITE FOL B \\
\hline 276 & 574 & Groupe des Sous & $\mathrm{BnF}, 40492256$, EO-487-BOITE FOL B \\
\hline 277 & 576 & Femmes arabes sur Baudet & GRI, 2008_r_3_3282 \\
\hline 278 & 576 & Grand derviche de Soudan & GRI, 2008_r_3_3297 \\
\hline 279 & 576 & Femmes arabes sur Baudets & GEH, 1983:1317:0003 \\
\hline 280 & 579 & Musique egyptienne[sic] & BnF, 40589991, IFN- 7702173 \\
\hline
\end{tabular}




\begin{tabular}{|c|c|c|c|}
\hline & A & $\mathrm{B}$ & C \\
\hline & 580 & Chanteuses arabes & BnF, 40492256, EO-487-BOITE FOL B \\
\hline & 581 & Epicurie[sic] Arab[sic] & GEH, 1978:1297:0029 \\
\hline 283 & 583 & Marchands de curiosites[sic] & $\mathrm{BnF}, 40589982$, IFN- 7702164 \\
\hline 284 & 585 & Untitled & BnF, 40492256, EO-487-BOITE FOL B \\
\hline 285 & 587 & Danseuses rabes[sic] & $\mathrm{BnF}, 40492256$, EO-487-BOITE FOL B \\
\hline 286 & 597 & Abanchards des[...] & BnF, 40492256, EO-487-BOITE FOL B \\
\hline 287 & 597 & Boutiques des ferblantiers & Francis Amin Mohareb Coll. \\
\hline 288 & 598 & Danse de Soudan & GRI, 2008_r_3_3293 \\
\hline 289 & 598 & Danse de Doudan & $\mathrm{BnF}, 40590054, \mathrm{FN}-7702237$ \\
\hline 290 & 598 & Danse de Soudan & $\mathrm{BnF}, 40492256$, EO-487-BOITE FOL B \\
\hline 291 & 598 & Diner arabe & UCL, 381-95 \\
\hline 292 & 602 & Groupe de Bedouines & GRI, unknown \\
\hline 293 & 603 & Panorama d'Assiout & NYPL, 85371 \\
\hline 294 & 604 & Nubie Prise d'un Crocodil & $\mathrm{BnF}, 40492256$, EO-487-BOITE FOL B \\
\hline 295 & 606 & Nubie, Richurins en voyage & $\mathrm{BnF}, 40492256$, EO-487-BOITE FOL B \\
\hline 296 & 608 & Epicerie[sic] arabe & AGO, $2008 / 121.8$ \\
\hline 297 & 608 & Nubee[sic] Bicharins & GEH, 1978:1297:0028 \\
\hline 298 & 608 & Épicérie arabe & $\mathrm{CCP}, \mathrm{T} 247 / \mathrm{S} 14 \mathrm{~B}, 78: 111: 021$ \\
\hline 299 & 608 & Epicerie[sic] arabe & $\mathrm{BnF}, 40492256$, EO-487-BOITE FOL B \\
\hline 300 & 613 & Louqsor[sic] Pylonade du grand[...] & $\mathrm{BnF}, 40492256$, EO-487-BOITE FOL B \\
\hline 301 & 613 & Dahabie[...] & Ebay, Pump Park Vintage Photography \\
\hline 302 & 616 & [A Syrian Shepherd] & National Galleries of Scotland, PGP R873 \\
\hline 303 & 617 & Des femmes arabes portant de l'eau du Nil & AUB, Jafet Library, $1 / 753$ \\
\hline 304 & 618 & Exportation dans le Nil & GEH, 1981:2125:0005 \\
\hline 305 & 619 & $\begin{array}{l}\text { Les arabes remplissant leurs crûches dans le } \\
\text { Nil }\end{array}$ & 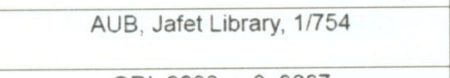 \\
\hline 306 & 620 & La prier[sic] & GRI, 2008_r_3_3287 \\
\hline 307 & 624 & Rue du Caire & GRI, 2008_r_3_3288 \\
\hline 308 & 624 & Rue du Caire & $\mathrm{CCP}, \mathrm{T} 247 / \mathrm{S} 14 \mathrm{~B}, 78: 111: 020$ \\
\hline 309 & 624 & Rue du Caire & Francis Amin Mohareb Coll. \\
\hline 310 & 625 & Arrosage des jardins au bord du Nil & $\mathrm{BnF}, 40590054, \mathrm{FN}-7702237$ \\
\hline 311 & 628 & Edfu Le[...] & GEH, 1978:1297:0025 \\
\hline 312 & 630 & Chadoufs de la Houte[sic] Egypte[sic] & AGO, 2008/121.41 \\
\hline 313 & 630 & Chadoufs de la Haute Egypte[sic] & GRI, 2008_r_3_3283 \\
\hline 314 & 630 & Chadoufs de la Haute Egypte[sic] & GEH, 2000:0817:0002 \\
\hline & 630 & Chadoufs de la haute Egypte[sic] & UCL, 313-92 \\
\hline
\end{tabular}




\begin{tabular}{|c|c|c|c|}
\hline & A & $\mathrm{B}$ & $\mathrm{C}$ \\
\hline 316 & 630 & Chadeof a[sic] la Haute Egypt[sic] & The Iznik Gallery Berlin \\
\hline 317 & 630 & Bords du Nil troupeau de buffles & BnF, 40589982, IFN- 7702164 \\
\hline 318 & 630 & Chadoufs de la Haute Egypte[sic] & Gr. Inst. Somers Clarke MSS. 11.144 \\
\hline 319 & 630 & Chadoufs de la Haute Egypt[sic] & LOC, LOT 13549-15, no. 2 [P\&P] \\
\hline 320 & 634 & Denderah Temple Athor & Gr. Inst. 6275 \\
\hline 321 & 635 & Karmak yalle & AUC, 19th Century photographs \\
\hline 322 & 637 & Edfou Pylone du temple de Horus & GEH, 1978:1297:0024 \\
\hline 323 & 638 & Les boeufs dans le Nil & GEH, 1981:2125:0002 \\
\hline 324 & 639 & Dahabie montant le Nil & GEH, 1981:2125:0001 \\
\hline 325 & 642 & [....]d'un mariage arabe & GRI, 2008_r_3_3280 \\
\hline 326 & 642 & Haute Eqypte[sic] Bateau postale & GEH, 2001:1522:0011 \\
\hline 327 & 642 & Obelisque[sic] d'Heliopolis & Gr. inst. 4100 \\
\hline 328 & 643 & Arabe prenant son caffe[sic] & AGO, 2008/121.6 \\
\hline 329 & 643 & Statue de Memphis a[sic] Sakkara & GEH, 1986:0309:0102 \\
\hline 330 & 643 & Saqquieh [wheel-operated well] & CCP, T247/S14B, 78:111:003 \\
\hline 331 & 644 & Sakkara tombeau Titi & BnF, 40589991, IFN- 7702173 \\
\hline 332 & 644 & Sakkara tombeau Titi & NYPL, 88442 \\
\hline 333 & 646 & Statue de Ramses a[sic] Louqsor[sic] & GEH, 1978:1297:0020 \\
\hline 334 & 646 & Assiout & GEH, 2001:1522:0008 \\
\hline 335 & 646 & Statue de Ramses a[sic] Louqsor & Gr. Inst.Somers Clarke MSS. 11.91 \\
\hline 336 & 646 & Thebes Memorium de Ramses III & Gr. Inst. 262 \\
\hline 337 & 646 & Assiut $[\ldots]$ & $\begin{array}{c}\text { Department of Egyptian and Classical Art. } \\
\text { The Brooklyn Museum }\end{array}$ \\
\hline 338 & 647 & Panoram $[\ldots]$ & GEH, 2001:1522:0014 \\
\hline 339 & $648 ?$ & Isis Osiris et Seti Abydos & $\mathrm{BnF}, 40589991$, IFN-7702173 \\
\hline 340 & 648 & illeg & AUC, 19th Century photographs \\
\hline 341 & 648 & Thebes Statue brisée de Ramses & Gr. Inst. 235 \\
\hline 342 & 651 & Thebes Colosses de Memnon & Gr. Inst. 244 \\
\hline 343 & 652 & Thiles Jombeau de Pboi Entrée du Caveau & Marta Braun Coll. \\
\hline 344 & 654 & [Group of Bedouins] & GRI, 2008_r_3_3284 \\
\hline 345 & 656 & Dervishes tourneurs & $\mathrm{BnF}, 40492256$, EO-487-BOITE FOL B \\
\hline 346 & 657 & $\begin{array}{l}\text { Karmak Procession des lengeres duns[sic] } \\
\text { I'aprirlement[sic] de granit[...] }\end{array}$ & Marta Braun Coll. \\
\hline 347 & 658 & Untitled & BnF, 40492256, EO-487-BOITE FOL B \\
\hline 348 & 658 & $\begin{array}{l}\text { Thebes Medinet Abu Vue generale[sic] } \\
\text { triangulaire du temple de Touthmes II et }\end{array}$ & Gr. Inst. 6261 \\
\hline 349 & 660 & Thebes colosses de Memnon & GEH, 1978:1297:0021 \\
\hline 350 & 661 & $\begin{array}{l}\text { Thebes Ramsseon Vue panoramique avec } \\
\text { tombeaux des Rois }\end{array}$ & GEH, 1978:1297:0019 \\
\hline
\end{tabular}




\begin{tabular}{|c|c|c|c|}
\hline & A & B & C \\
\hline 351 & 662 & Diner arabe & CCP, T247/S14B, 78:111:017 \\
\hline 352 & 662 & Diner arabe & $\mathrm{BnF}, 40590054, \mathrm{FN}-7702237$ \\
\hline 353 & 662 & $\begin{array}{c}\text { Thebes Abeninet Abou historique du temple de } \\
\text { Touthires }\end{array}$ & BnF, 40492256, EO-487-BOITE FOL B \\
\hline 354 & 663 & Thèbes Daìr el Bahri & Gr. Inst. 205 \\
\hline 355 & 664 & Épicérie arabe & CCP, T247/S14B, 78:111:009 \\
\hline 356 & 664 & Epicerie[sic] arabe & LOC, LOT $13549-15$, no. 3 [P\&P] \\
\hline 357 & 666 & illeg & BnF, 40588367, MFILM SG W-115 \\
\hline 358 & 666 & $\begin{array}{c}\text { Thebes Abedinet Abou vue generale triangularie } \\
\text { du temple de Touffines de[...] }\end{array}$ & BnF, 40492256, EO-487-BOITE FOL B \\
\hline 359 & 667 & Thebes Interieur[sic] de Tombe Roi N [...] & Ebay, jibooks \\
\hline 360 & 669 & Loucsor[sic] Jardin de Loucsor Hotel & GEH, 2001:1522:0002 \\
\hline 361 & 670 & Thebes temple $[\ldots]$ & Ebay, jibooks \\
\hline 362 & 671 & Louqsor[sic] Le pylone les statues de Ramses & GEH, 1978:1297:0018 \\
\hline 363 & 672 & Chadouf a[sic] la haute Egypte[sic] & UCL, 314-92 \\
\hline 364 & 672 & Chadeof[sic] a[sic] la Haute Egypt[sic] & BnF, 40492256, EO-487-BOITE FOL B \\
\hline 365 & 672 & Chadouf a[sic] la Haute Egypte[sic] & Gr. Inst. Somers Clarke MSS. 11.130 \\
\hline 366 & 672 & Chadouf a[sic] la Haute Egypte[sic] & Ebay, photobazaar \\
\hline 367 & 674 & $\begin{array}{l}\text { Louqsor[sic] propylone du temple de[.... Jet les } \\
\text { statues de[...] }\end{array}$ & GEH, 2001:1522:0004 \\
\hline 368 & 676 & Thebes tableau dans la tombe du roi $\mathrm{N}$ & BnF, 40589991, IFN- 7702173 \\
\hline 369 & 677 & Fileurs de sois & Gr. Inst. 4102 \\
\hline 370 & 678 & illeg & BnF, 40588367, MFILM SG W- 115 \\
\hline 371 & 678 & Temple de Louqsor.[sic] & NYPL, 88432 \\
\hline 372 & 678 & Temple de Louqsor & Marta Braun Coll. \\
\hline 373 & 679 & Thebes Entree de tombe de roi No 6 & Gr. Inst. 4D \\
\hline 374 & 682 & Karnak grand temple salle hypostyle intérieur & NYPL, 88435 \\
\hline 375 & 683 & Karnak Obelisque[sic] et ruines du 4 me pylone & Gr. Inst. Somers Clarke MSS. 11.70 \\
\hline 376 & 685 & Vue generalle[sic] de Louqur[sic] & Gr. Inst. 175 \\
\hline 377 & 688 & Karnak Interieur[sic] du temple de K & GEH, 1978:1297:0016 \\
\hline 378 & 690 & Ane de race & $\mathrm{BnF}, 40590054, \mathrm{FN}-7702237$ \\
\hline 379 & 692 & $\begin{array}{c}\text { Karmak Façade grand temple pris du l'avenue } \\
\text { de Beluns }\end{array}$ & BnF, 40492256, EO-487-BOITE FOL B \\
\hline 380 & 692 & Luksor[sic] Grande colonnade prise de profil & Gr. Inst. 6268 \\
\hline 381 & 695 & Karnak Salle hypostyle interieur[sic] & GEH, 1978:1297:0030 \\
\hline 382 & 696 & Le sommeil profond & CCP, T247/S14B, 78:111:011 \\
\hline 383 & 696 & $\begin{array}{l}\text { Karnak Courdes colonnies du temple de } \\
\text { Khoui[...] }\end{array}$ & AUC, 19th Century photographs \\
\hline 384 & 696 & Le troi Ramses de Louqso[sic]r & Gr. Inst. 199 \\
\hline 385 & 697 & Karmak Interieur[sic] du temple de Kohons & BnF, 40492256, EO-487-BOITE FOL B \\
\hline
\end{tabular}




\begin{tabular}{|c|c|c|c|}
\hline & A & $\mathrm{B}$ & $\mathrm{C}$ \\
\hline 386 & 698 & Karmak Ruins obelisques[sic] de & $\mathrm{BnF}, 40492256, \mathrm{EO}-487-\mathrm{BOITE}$ FOL B \\
\hline 387 & 699 & Louksor[sic] Obelisque[sic] de Tothmes Ire & Gr. Inst. 6265 \\
\hline 388 & 701 & Colonade a[sic] Louqsor[sic] & Gr. Inst. 181 \\
\hline 389 & 702 & Karnak Temple le Khons Interieur[sic] & GEH, 1986:0310:0001 \\
\hline 390 & 703 & Statue de Ramses a[sic] Louqsor & BnF, 40589991, IFN- 7702173 \\
\hline 391 & 707 & Karnak temple de Khons & BnF, 40588367, MFILM SG W-115 \\
\hline 392 & 708 & $\begin{array}{l}\text { Haute-Egypte[sic] Jeunes filles vendeuses } \\
\text { d'eau }\end{array}$ & The University of Tennessee \\
\hline 393 & 710 & Karnak Temple le Khons Phumses au femme & AUC, 19th Century photographs \\
\hline 394 & 711 & Colonade a[sic] Louqsar[sic] & GEH, 2001:1522:0006 \\
\hline 395 & 712 & Louksor[sic] colonnades du temple & $\mathrm{BnF}, 40589991, \mathrm{IFN}-7702173$ \\
\hline 396 & 713 & $\begin{array}{l}\text { Vue generale[sic] du temple et de lac sacre[sic] } \\
\text { Karmak }\end{array}$ & Marta Braun Coll. \\
\hline 397 & 723 & Des femmes arabes portant leau du Nil & GRI, 2008_r_3_3281 \\
\hline 398 & 723 & Abydos Offrande Soli & NYPL, 87080 \\
\hline 399 & 723 & Karnak Temple [...] & Ebay, jibooks \\
\hline 400 & 725 & Abydos Tableau des 76 Rois d' Egypte[sic] & GEH, 1986:0309:0084 \\
\hline 401 & 729 & Pylon du temple d'Athor a[sic] Denderah & Ebay, bb1913 \\
\hline 402 & 730 & Temple Athor Denderah & Gr. Inst. Somers Clarke MSS. 11.104 \\
\hline 403 & 731 & Karnak Salle hypostyle du grand temp[le & Gr. Inst. 114 \\
\hline 404 & 737 & Deux femmes arabes & UCL, 259-61 \\
\hline 405 & 738 & Vendeuses de fruits & $\mathrm{BnF}, 40590054, \mathrm{FN}-7702237$ \\
\hline 406 & 738 & Karnak Grande porte de Ptolemée & Gr. Inst. 93 \\
\hline 407 & 740 or 140 & $\begin{array}{l}\text { Phylae Temple d'Isis Interieur[sic] du premier } \\
\text { pylons }\end{array}$ & GEH, 1978:1297:0017 \\
\hline 408 & 743 & $\begin{array}{l}\text { Karnak Grand temple Salle hypostyle } \\
\text { intérieure[sic] d[...] }\end{array}$ & Gr. Inst. 6260 \\
\hline 409 & 747 & Philae façade du temple d'Isis & $\begin{array}{l}\text { Bassenge Kunst- Und Buchauktionen, LOT } \\
\qquad 4278\end{array}$ \\
\hline 410 & 749 & Jeunes filles fellah & $\mathrm{BnF}, 40590054, \mathrm{FN}-7702237$ \\
\hline 411 & $750 ?$ & $\begin{array}{c}\text { Pyramide de Cheops le Sphinx et les } \\
\text { catacombes }\end{array}$ & BnF, 40589991, IFN-7702173 \\
\hline 412 & 750 & [Two Women] & Marcuse Pfeifer Gallery, New York \\
\hline 413 & 751 & Vue du Caire et Mosquee[sic] de Mohamed Aly & BnF, 40492256, EO-487-BOITE FOL B \\
\hline 414 & 752 & Nurrice[sic] de negrus[sic] d'Abyssine & BnF, 40492256, EO-487-BOITE FOL B \\
\hline 415 & 753 & Ile. de rocher Konosso & GEH, 2001:1522:0003 \\
\hline 416 & 754 & Assouan Gare du chemin de fer & $\begin{array}{c}\text { Department of Egyptian and Classical Art, } \\
\text { The Brooklyn Museum }\end{array}$ \\
\hline 417 & 755 & Le Caire porte de la citadelle & $\mathrm{BnF}, 40589982$, IFN- 7702164 \\
\hline 418 & 756 & Assouan premier Cataracte & $\begin{array}{l}\text { Bassenge Kunst- Und Buchauktionen, LOT } \\
\qquad 4278\end{array}$ \\
\hline 419 & 757 & Caire vue d'ensemble & BnF, 40492256, EO-487-BOITE FOL B \\
\hline 420$]$ & 757 & Assouan vue panoramique & BnF, 40492256, EO-487-BOITE FOL B \\
\hline
\end{tabular}




\begin{tabular}{|c|c|c|c|}
\hline & A & $\mathrm{B}$ & C \\
\hline 421 & 758 & Vue generale[sic] du Caire & BnF, 40589991, IFN- 7702173 \\
\hline 422 & $759 ?$ & Groupe de femmes fellahs au bord du Nil & $\mathrm{BnF}, 40589982$, IFN-7702164 \\
\hline 423 & 763 & Assouan Tombeau d' Amenhotep 1466 a. J.C. & GEH, 2001:1522:0009 \\
\hline 424 & 764 & Edfou Interieur[sic], premiere cour & Gr. Inst. 754 \\
\hline 425 & 765 & Assouan vue panoramique & GEH, 2001:1522:0010 \\
\hline 426 & 765 & Assouan vue panoramique & Marta Braun Coll. \\
\hline 427 & 766 & Assouan Cataracte segonde[sic] porte & GEH, 1978:1297:0026 \\
\hline 428 & 766 & Femme arabe sur un baudet avec son enfant & $\mathrm{BnF}, 40590054, \mathrm{FN}-7702237$ \\
\hline 429 & 767 & Assouan Bains de Cleopatra et ile Elephantine & GEH, 2001:1522:0013 \\
\hline 430 & 767 & Assouan Bains de Cleopatra et ile Elephantine & Marta Braun Coll. \\
\hline 431 & 767 & Edfou Coure du temple de Horous & Gr. Inst. 751 \\
\hline 432 & 768 & Saqquieh Egypte[sic] & NYPL, 81454 \\
\hline 433 & 769 & Edfou Bas-relief du temple de Horus & Gr. Inst. 6274 \\
\hline 434 & 770 & Tombeaux des Mamelouks Caire & GEH, 1981:2126:0005 \\
\hline 435 & 771 & Moulet-el-Neby fête arabe & NYPL, 88439 \\
\hline 436 & 772 & Passage au Pont de Kasr el Nil & GEH, 1981:2125:0006 \\
\hline 437 & 773 & Femme arabe avec le jep & GRI, 2008_r_3_4752 \\
\hline 438 & 774 & Edfou Interieur[sic] du temple de Horous & Gr. Inst. 757 \\
\hline 439 & 775 & Inondation au Pyramides & GEH, 1981:2125:0007 \\
\hline 440 & 777 & Vendeuse d'eau & $\mathrm{BnF}, 40590054, \mathrm{FN}-7702237$ \\
\hline 441 & 777 & Pyramide de Chefken & $\mathrm{BnF}, 40492256$, EO-487-BOITE FOL B \\
\hline 442 & 779 & Edfou interieur[sic]. Barque [...] & Gr. Inst. 763 \\
\hline 443 & 780 & Jeune fille arabe & $\mathrm{BnF}, 40590054, \mathrm{FN}-7702237$ \\
\hline 444 & 780 & Jeune fille arabe & UCL, 364-95 \\
\hline 445 & 781 & Vue du Caire et Mosque[sic] Soillon Hassan & AUC, 19th Century photographs \\
\hline 446 & 782 & Bord du Nil et Pyramides & BnF, 40492256, EO-487-BOITE FOL B \\
\hline 447 & $784 ?$ & Saqqieh & NYPL, 81450 \\
\hline 448 & 785 & Nil de Boulak Caire & NYPL, 81489 \\
\hline 449 & $786 ?$ & Le Caire Halig & $\mathrm{BnF}, 40589982$, IFN-7702164 \\
\hline 450 & 787 & Bord du Nil a[sic] Boulaq & GEH, 1981:2125:0008 \\
\hline 451 & 792 & Assouan Nile $[\ldots]$ & Marta Braun Coll. \\
\hline 452 & 792 & Inundation du Nil et palmiers & NYPL, 88440 \\
\hline 453 & 793 & Palmiers et pyramides & BnF, 40589982, IFN- 7702164 \\
\hline 454 & 793 & Palmiers et Pyramides & Ebay, jibooks \\
\hline 455 & $794 ?$ & Le Caire vue generale[sic] & $\mathrm{BnF}, 40589982$, IFN-7702164 \\
\hline
\end{tabular}




\begin{tabular}{|c|c|c|c|}
\hline & A & $\mathrm{B}$ & $\mathrm{C}$ \\
\hline 456 & $794 ?$ & Le Caire Ziker fete[sic] arabe & $\mathrm{BnF}, 40589982$, IFN-7702164 \\
\hline 457 & 796 & Sphynx decouvert[sic] & BnF, 40492256, EO-487-BOITE FOL B \\
\hline 458 & 800 & Dame turque sur divan & $\begin{array}{l}\text { The Oriental Institute of University of } \\
\text { Chicago, lost egypt catalog }\end{array}$ \\
\hline 459 & 802 & Entree[sic] du Pont de Kasr-el-Nil & UCL, $183-86$ \\
\hline 460 & 803 & Femme arabe femme turque & BnF, 40492256, EO-487-BOITE FOL B \\
\hline 461 & 804 & Femme turque voilee[sic] & $\mathrm{BnF}, 40590054, \mathrm{FN}-7702237$ \\
\hline 462 & 805 & Femme turque & $\begin{array}{l}\text { The Oriental Institute of University of } \\
\text { Chicago, lost egypt catalog }\end{array}$ \\
\hline 463 & 806 & Deuse[sic] femmes turques & BnF, 40492256, EO-487-BOITE FOL B \\
\hline 464 & 807 & Rue mosquee[sic] des pharaons Caire & BnF, 40589991, IFN- 7702173 \\
\hline 465 & 808 & Phylae cote[sic] nrod[sic] & NYPL, 85369 \\
\hline 466 & 810 & Philae façade du temple d'Isis & Gr. Inst. 801 \\
\hline 467 & 812 & Le Caire & BnF, 40589982, IFN- 7702164 \\
\hline 468 & 813 & Caire Vue Panoramique & UCL, $182-86$ \\
\hline 469 & $813 ?$ & Marchand de curiosites[sic] & BnF, 40589982, IFN-7702164 \\
\hline 470 & 814 & $\begin{array}{l}\text { Groupe des minarees[sic] Mosquee[sic] EI } \\
\text { eAzhur Cairo }\end{array}$ & Marta Braun Coll. \\
\hline 471 & 817 & Phylae panorama du nord & NYPL, 85370 \\
\hline 472 & 818 & Phylae La Kiosque d'Isis & Gr. Inst. 813 \\
\hline 473 & 820 & Philae Temple d'Isis et le Nil & Gr. Inst. 814 \\
\hline 474 & 825 & Mosquee[sic] Saida Zeynab Caire & GEH, 1981:2125:0003 \\
\hline 475 & 825 & Le Caire mosquee[sic] Saida-Zeynab & BnF, 40589982, IFN-7702164 \\
\hline 476 & 829 & Mosquee[sic] El- Husseni Caire & GEH, 1981:2126:0003 \\
\hline 477 & 834 & Souk-el Selah Cairo & Marta Braun Coll. \\
\hline 478 & 835 & Grand bazar[sic] de Kasr-el-Nil Caire & GRI, 2008_r_3_3276 \\
\hline 479 & 845 & Almee[sic] arabe dansant & BnF, 40589991, IFN- 7702173 \\
\hline 480 & 849 & Arivee[sic] du M[ahme]l Caire & GEH, 1981:2126:0002 \\
\hline 481 & 852 & La Mosquee[sic] Sultan Bebars Caire & GEH, 1981:2126:0001 \\
\hline 482 & $852 ?$ & Thebes tombeau du roi entrée du caveau & NYPL, 88434 \\
\hline 483 & 854 & Deux femmes egyptiennes[sic] avec enfant & BnF, 40589991 , IFN-7702173 \\
\hline 484 & 855 & Panorama du Vieux Caire et Pyramides & GEH, 1981:2125:0012 \\
\hline 485 & 855 & Panorama du Vieux Caire et pyramide & UCL, $181-86$ \\
\hline 486 & 858 & Chanteuse felah & AUB, Jafet Library, $1 / 732$ \\
\hline 487 & 862 & Grand Chech arabe & AUB, Jafet Library, $1 / 460$ \\
\hline 488 & $862 ?$ & Le Caire rue de Boulaq & $\mathrm{BnF}, 40589982$, IFN-7702164 \\
\hline 489 & 863 & Jeune fille sur balansoine[sic] & $\mathrm{BnF}, 40492256$, EO-487-BOITE FOL B \\
\hline 490 & 865 & Voyage d'une Desespere[sic] & $\mathrm{BnF}, 40492256$, EO-487-BOITE FOL B \\
\hline
\end{tabular}




\begin{tabular}{|c|c|c|c|}
\hline & A & $\bar{B}$ & $\bar{C}$ \\
\hline 491 & 869 & Panorama d'Asseout & UCL, 40-85 \\
\hline 492 & 871 & Bazar[sic] d'Assout & Gr. Inst. 6206 \\
\hline 493 & 875 & Marchand d'arghissous[...] & $\mathrm{BnF}, 40589991, \mathrm{IFN}-7702173$ \\
\hline 494 & 875 & Abydos Facade du temple & Gr. Inst. 6029 \\
\hline 495 & 876 & Abydos Colonnade du Memnonium & Gr. Inst. 4107 \\
\hline 496 & 876 & Abydos Colonnade du Memnonium & Gr. Inst. 6032 \\
\hline 497 & 878 & Dompteur arabe avec un ane[sic] et un baboun & $\mathrm{BnF}, 40589991$, IFN- 7702173 \\
\hline 498 & 878 & Seti[sic] Osiris à Abydos & Gr. Inst. 6030 \\
\hline 499 & 879 & Musique Egyptienne[sic] & AUB, Jafet Library, $1 / 746$ \\
\hline 500 & 880 & Abydos Interieur[sic] & AGO, 2008/ 121.4 \\
\hline 501 & 880 & Abydos interieur[sic] & GRI, 2008_r_3_3259 \\
\hline 502 & 880 & Sous l'hombre & BnF, 40492256, EO-487-BOITE FOL B \\
\hline 503 & 880 & Abydos Interieur[sic] & Gr. Inst. 6036 \\
\hline 504 & 881 & Deux femmes abyssines & BnF, 40589991, IFN- 7702173 \\
\hline 505 & 881 & $\begin{array}{l}\text { Abydos Seti[sic] reçoi[sic] les homages[sic] de } \\
\text { Chnubis }\end{array}$ & Gr. Inst. 6031 \\
\hline 506 & 883 & Abydos Offrande de Seti[sic] & Gr. Inst. 6035 \\
\hline 507 & 884 & Abydos Interieur[sic] du temple & Gr. Inst. 6039 \\
\hline 508 & 885 & illeg & $\mathrm{BnF}, 40588367, \mathrm{MFILM}$ SG W-115 \\
\hline 509 & 886 & Isis offrande[sic] Seti les ablemes[sic] de la [...] & Gr. Inst. 6033 \\
\hline 510 & 892 & Prier[sic] arabe & UCL, 315-92 \\
\hline 511 & 892 & Abydos Horus et Osiris $[\ldots]$ & Gr. Inst. 4108 \\
\hline 512 & 893 & Abydos Anubis et Horus & Gr. Inst. 6034 \\
\hline 513 & 894 & Abydos Interieur[sic] du temple & Gr. Inst. 6038 \\
\hline 514 & 894 & Abydos Interieur[sic] du temple & Gr. Inst. 6208 \\
\hline 515 & 895 & Abydos Ramses II et Petit & AGO, 2008/121.3 \\
\hline 516 & 897 & Isis Osiris et Seti[sic] Abydos & Gr. Inst. 6037 \\
\hline 517 & 898 & Le someille[sic] proude & BnF, 40492256, EO-487-BOITE FOL B \\
\hline 518 & 900 & Denderah temple Athor & AGO, $2008 / 121.1$ \\
\hline 519 & 901 & Denderah Entrée d'antinaos & AGO, 2008/ 121.43 \\
\hline 520 & 901 & Denderah Entrée d'antinaos & Gr. Inst. 6041 \\
\hline 521 & 902 & Denderah Colonnade & UCL, $100-85$. \\
\hline 522 & 903 & Obelisque[sic] [...] la salle hypostyle & Gr. Inst. 6225 \\
\hline 523 & 904 & Femmes arabes sur baudets & NYPL, 88441 \\
\hline 524 & 904 & façade temple de Denderah & Gr. Inst. 6042 \\
\hline 525 & 905 & Isis & BnF, 40589991, IFN- 7702173 \\
\hline
\end{tabular}




\begin{tabular}{|c|c|c|c|}
\hline & A & B & C \\
\hline 526 & 905 & Denderah [...] & Gr. Inst, 6209 \\
\hline 527 & 906 & Offrande de Ramsis Denderah & UCL, 95-85 \\
\hline 528 & 909 & Rue du vieux Caire & BnF, 40589991, IFN- 7702173 \\
\hline 529 & $916 ?$ & Elyados Taeade du temple & BnF, 40492256, EO-487-BOITE FOL B \\
\hline 530 & 920 & Thebes e[sic] Memorium de Ramses III & AGO, 2008/ 121.44 \\
\hline 531 & 922 & $\begin{array}{l}\text { Thebes Medinet Abou grand temple Touthmes II } \\
\text { salle des colonnes }\end{array}$ & Gr. Inst. 6237 \\
\hline 532 & 926 & $\begin{array}{l}\text { Statue de Ramses III [...see] du Ramesseum } \\
\text { Thebes }\end{array}$ & AGO, 2008/ 121.9 \\
\hline 533 & 927 & Thebes Madinat Abou cour des Garyulides & UCL, $120-85$ \\
\hline 534 & 928 & Colonade du grand tonyide de Louqor[sic] & AUC, 19th Century photographs \\
\hline 535 & 930 & $\begin{array}{c}\text { Thebes Vue de Temple de Touthmes II et de } \\
\text { Ramses III }\end{array}$ & UCL, 121-85 \\
\hline 536 & 932 & Medinet Abou. Péristyle du temple de[...] & AUB, Jafet Library, 1/676 \\
\hline 537 & 933 & Thebes Tableaux dans le tombe de roi No 6 & Gr. Inst. 5 \\
\hline 538 & 934 & Thebes Interieur[sic] de tombe roi No. 6 & AGO, 2008/ 121.7 \\
\hline 539 & 936 & Thebes Interieur[sic] de tombe [...] No. 6 & UCL, $122-85$ \\
\hline 540 & 937 & Thèbes Interieur[sic] [...] No 9 & Gr. Inst. 6211 \\
\hline 541 & 937 & Thèbes Interieur[sic] [...] No 9 & Gr. Inst. 6215 \\
\hline 542 & 941 & Panorama du Vieux Caire et [Pyramides] & BnF, 40588367, MFILM SG W-115 \\
\hline 543 & 943 & Femme Armeniere[sic] & BnF, 40492256, EO-487-BOITE FOL B \\
\hline 544 & 944 & $\begin{array}{c}\text { Tombe de roi cartouches de Ramessou- } \\
\text { Meramen }\end{array}$ & Musée d'Orsay \\
\hline 545 & 945 & Dame Armenienne[sic] & BnF, 40492256, EO-487-BOITE FOL B \\
\hline 546 & 945 & Thebes Entree de tombe de noi[sic] N. 6 & BnF, 40492256, EO-487-BOITE FOL B \\
\hline 547 & 945 & Thebes Entrée de tombe de roi No 6 & Gr. Inst. $4 \mathrm{C}$ \\
\hline 548 & 946 & Thebes tombe de roi No.9 & AGO, 2008/ 121.46 \\
\hline 549 & 946 & Dame tuque[sic] sur divan & BnF, 40492256, EO-487-BOITE FOL B \\
\hline 550 & 946 & Thèbes, tombe de roi No. 9 & AUB, Jafet Library, $1 / 710$ \\
\hline 551 & 947 & Thèbes Tombe N.17 Seti N.1 & Gr. Inst. 4110 \\
\hline 552 & 947 & Thèbes Tombe N.17 Seti N.1 & Gr. Inst. 6219 \\
\hline 553 & 948 & Dame Syrienne & BnF, 40492256, EO-487-BOITE FOL B \\
\hline 554 & 949 & Thebes Tombe de roi $\mathrm{N} 15[\ldots]$ & Gr. Inst. 6216 \\
\hline 555 & 950 & Karmak Palle Hiyerospyle di s touler[...] & Marta Braun Coll. \\
\hline 556 & 950 & Phylae Interieur[sic] du temple d'[...] & BnF, 40492256, EO-487-BOITE FOL B \\
\hline 557 & 953 & Vue generalle[sic] de Louqur[sic] & AGO, 2008/ 121.17 \\
\hline 558 & 956 & Luksor Stastue de la femme de $[\ldots]$ & Gr. Inst. 6232 \\
\hline 559 & 957 & Danseuse turque & $\mathrm{BnF}, 40492256, \mathrm{EO}-487-\mathrm{BOITE}$ FOL B \\
\hline 560 & 959 & Luksor[sic] Colonnade du Temple & UCL, 124-85 \\
\hline
\end{tabular}




\begin{tabular}{|c|c|c|c|}
\hline & A & $\mathrm{B}$ & $\mathrm{C}$ \\
\hline 561 & 966 & L'arbre Doum a[sic] la Aute Egypte[sic] & Gr. Inst. 6207 \\
\hline 562 & 968 & Louxor Statue de Ramsis III & UCL, 70-85 \\
\hline 563 & 970 & Danceuse du theatre[sic] & GRI, unknown \\
\hline 564 & 970 & Louqsor[sic] colonnade du petit temple & GRI, 2008_r_3_4149 \\
\hline 565 & 973 & Colonnade du grand temple de Louksor[sic] & UCL, 69-85 \\
\hline 566 & 975 & Louxor ensemble des colonnades & AGO, 2008/ 121.12 \\
\hline 567 & 976 & Luxor Grande colonnade prise de profil & BnF, 40492256, EO-487-BOITE FOL B \\
\hline 568 & 977 & Louksor[sic] Colonnade du temple & Gr. Inst. 6287 \\
\hline 569 & 978 & Louksor[sic] Obelisque[sic] de Tothmes I & UCL, 68-85 \\
\hline 570 & 980 & Louqsor[sic] Ensemble de Colonnade & UCL, $123-85$ \\
\hline 571 & 980 & Luqsor[sic] Ensemble de colonnade & Gr. Inst. 4113 \\
\hline 572 & 980 & Luqsor[sic] Ensemble de colonnade & Gr. Inst. 6233 \\
\hline 573 & 980 & Danseuses turques & $\begin{array}{l}\text { Arnold H. Crane Collection, Doug Munson } \\
\text { Photos }\end{array}$ \\
\hline 574 & 983 & Karnak Temple de Khous, intérieur & AUB, Jafet Library, 1/641 \\
\hline 575 & 984 & Salle hypostyle de grand temple a[sic] Karnak & Gr. Inst. 6227 \\
\hline 576 & 985 & Karnak salle hypostyle & UCL, $103-85$ \\
\hline 577 & 986 & Karnak Salle hypostyle [...] & Gr. Inst. 6226 \\
\hline 578 & 987 & Karnak temple de Khons interieur[sic] & Gr. Inst. 6228 \\
\hline 579 & 988 & Vue générale du temple et le lac sacre[sic] & GRI, 2008_r_3_3258 \\
\hline 580 & 989 & Karnak Grand temple et Colonne penchee[sic] & UCL, $117-85$ \\
\hline 581 & 995 & Karnak Temple de Khons Ramses sa femme & Gr. Inst. 6229 \\
\hline 582 & 997 & Karnak Salle $[. .$.$] colonne de[...]De Sud-Ouest$ & UCL, $118-85$ \\
\hline 583 & $? 50$ & Palais du sultan au Caire[...] & $\mathrm{BnF}, 40589991, \mathrm{IFN}-7702173$ \\
\hline 584 & 1000 & $\begin{array}{l}\text { Karnak Tableau de Victoire sur les ruines du } \\
\text { petit temple }\end{array}$ & Gr. Inst. 6210 \\
\hline 585 & 1002 & Vue de Jerusalem[sic] prise de Bethesda & UCL, $111-85$ \\
\hline 586 & 1003 & $\begin{array}{l}\text { Karnak Ruine obelisque[sic] de Touthmes ler et } \\
\text { de sa fille Hatasu }\end{array}$ & AGO, 2008/ 121.39 \\
\hline 587 & 1004 & Mosquee[sic] d'Omar interieur[sic] (Le Rocher) & UCL, 394-95 \\
\hline 588 & 1005 & Karnak Ruines et colonnes de[...] & AUB, Jafet Library, 1/626 \\
\hline 589 & 1005 & Karnak [...] & Ebay, photobazaar \\
\hline 590 & 1008 & Untitied & BnF, 40492256, EO-487-BOITE FOL B \\
\hline 591 & 1008 & (Jérusalem) Olivier de Jardin de Gethsémané & AUB, Jafet Library, 1/339 \\
\hline 592 & 1009 & $\begin{array}{l}\text { Karnak Grand te[n]le avec Obelisque[sic] de } \\
\text { Touthmes }\end{array}$ & AGO, 2008/121.35 \\
\hline 593 & 1009 & (Jérusalem) Gethsemani, Arbre de l'agonie & AUB, Jafet Library, $1 / 338$ \\
\hline 594 & 1011 & Jerusalem [Valley of Jehoshapha] & GEH, 1973:0230:0026 \\
\hline 595 & 1012 & (Jerusalem)[sic] Village de Siloam & GEH, 1973:0230:0036 \\
\hline
\end{tabular}




\begin{tabular}{|c|c|c|c|}
\hline & A & $B$ & C \\
\hline 596 & 1012 & Karnak Intérieur du Temple de[...] & AUB, Jafet Library, $1 / 642$ \\
\hline 597 & 1013 & Karnak Salle hypostyle du grand temple & AUB, Jafet Library, 1/619 \\
\hline 598 & 1014 & Karnak Interieur[sic] [...] & Ebay, photobazaar \\
\hline 599 & 1016 & $\begin{array}{l}\text { (Jérusalem) Eglise[sic] Russe sur le mont de } \\
\text { Oliviers }\end{array}$ & AUB, Jafet Library, 1/386 \\
\hline 600 & 1017 & [Village] & UCL, $151-85$ \\
\hline 601 & 1018 & Esneh Colones du temple & Gr. Inst. 6043 \\
\hline 602 & 1020 & Esneh Parroi demierement[sic] deteré & Gr. Inst. 6044 \\
\hline 603 & 1022 & Jerusalem [The Grotto of Jeremiah] & GEH, 1973:0230:0025 \\
\hline 604 & 1024 & Edfou Interieur[sic] du temple & AGO, 2008/ 121.27 \\
\hline 605 & 1025 & Edfou Vue generale[sic] du temple & AGO, 2008/121.13 \\
\hline 606 & 1025 & [Jerusalem] & BnF, 40589747, MFILM SG WD-286 \\
\hline 607 & 1025 & Edfou Vue generale[sic] du temple & $\mathrm{BnF}, 40492256$, EO-487-BOITE FOL B \\
\hline 608 & 1025 & Edfu Vue generale[sic] du temple & UCL, $104-85$ \\
\hline 609 & 1025 & Edfou Vue generale[sic] du temple & Gr. Inst. 6045 \\
\hline 610 & 1026 & Edfou Pyione du temple de Horus & AGO, 2008/ 121.28 \\
\hline 611 & 1026 & Vue generale[sic] du Jerusalem[sic] & UCL, $110-85$ \\
\hline 612 & $1027 ?$ & Vue de Jérusalem prise sur le Bethesda & AUB, Jafet Library, $1 / 344$ \\
\hline 613 & 1032 & Edfou Interieur[sic] & AGO, 2008/ 121.26 \\
\hline 614 & 1032 & Panorama de Jerusalem[sic] & GEH, 1973:0230:0003 \\
\hline 615 & 1032 & Edfou Interieur[sic] & Gr. Inst. 6289 \\
\hline 616 & $1034 ?$ & (Jérusalem). Tour de David & AUB, Jafet Library, 1/365 \\
\hline 617 & 1034 & Edfou Bas-relief du temple de Horus & Gr. Inst. 6046 \\
\hline 618 & 1037 & Edfou Bas-relief du temple de Horus & AGO, 2008/ 121.30 \\
\hline 619 & 1037 & (Jérusalem) Porte dorée & AUB, Jafet Library, 1/360 \\
\hline 620 & 1038 & $\begin{array}{l}\text { (Jerusalem) Porte de Damas The Damascus } \\
\text { State }\end{array}$ & GEH, 1973:0230:0024 \\
\hline 621 & 1038 & Edfou Interieur[sic] du temple de Horous & Gr. Inst. 6243 \\
\hline 622 & 1040 & (Jerusalem)[sic] Porte de Saint-Etienne[sic] & GEH, 1973:0230:0012 \\
\hline 623 & 1040 & (Jérusalem) Porte de Sainte-Etienne & AUB, Jafet Library, 362 \\
\hline 624 & 1042 & (Jérusalem) Couvent Arménien & AUB, Jafet Library, $1 / 387$ \\
\hline 625 & 1043 & Bas-relief du temple de Horous & AGO, 2008/121.31 \\
\hline 626 & $1043 ?$ & Une Rue à Jérusalem & AUB, Jafet Library, 1/366 \\
\hline 627 & 1044 & Une Rue à Jérusalem & AUB, Jafet Library, 1/367 \\
\hline 628 & 1045 & Vue generale[sic] de Jerusalem[sic] & UCL, 395-95 \\
\hline 629 & 1052 & Assouan Tombeau d'Amenhotep. 1466 a. J.C. & Gr. Inst. 6028 \\
\hline 630 & 1053 & Assouan [...]cataracte rapide & AUB, Jafet Library, 1/678 \\
\hline
\end{tabular}




\begin{tabular}{|c|c|c|c|}
\hline & A & $\mathrm{B}$ & C \\
\hline 631 & 1056 & Assouan premier caracte[sic] & AGO, 2008/121.34 \\
\hline 632 & 1058 & $\begin{array}{c}\text { Jerusalem The Mosque of Omar (Mosquee[sic] } \\
\text { d'Omar et Tribunal de [...]) }\end{array}$ & GEH, 1973:0230:0017 \\
\hline 633 & 1058 & Cataracte d'Assouan & GRI, 2008_r_3_3260 \\
\hline 634 & 1062 & Elephantine au[sic] est & GRI, 2008_r_3_3499 \\
\hline 635 & 1066 & $\begin{array}{l}\text { (Jerusalem)[sic] Maison de Pilate Temple } \\
\text { enclosure The House of Pilate }\end{array}$ & GEH, 1973:0230:0023 \\
\hline 636 & 1066 & $\begin{array}{c}\text { (Jérusalem) Maison de Pilate } \\
\text { Houses }\end{array}$ & AUB, Jafet Library, $1 / 390$ \\
\hline 637 & $1067 ?$ & (Jérusalem) Intérieur de la maison du Kaiphe & AUB, Jafet Library, 1/389 \\
\hline 638 & 1069 & $\begin{array}{c}\text { (Jerusalem) Maison de Pilate Temple enclosure } \\
\text { The House of Pilate }\end{array}$ & GEH, 1973:0230:0021 \\
\hline 639 & 1069 & [...]Phylae. Panorama & AUB, Jafet Library, 1/507 \\
\hline 640 & 1070 & Phylae. Pointe de l'île & AUB, Jafet Library, $1 / 505$ \\
\hline 641 & 1073 & [Phylae] & AUB, Jafet Library, $1 / 510$ \\
\hline 642 & 1074 & $\begin{array}{c}\text { Phylae Façade du pylone Auguste Imp. Isis et } \\
\text { H[...] }\end{array}$ & Gr. Inst. 6049 \\
\hline 643 & 1077 & $\begin{array}{l}\text { Philae Vue d'ensemble de colonnade temple } \\
\text { d'lsis }\end{array}$ & AGO, 2008/ 121.37 \\
\hline 644 & 1077 & $\begin{array}{l}\text { Philae Vue d'Ensemble de Colonnade Temple } \\
\text { d'isis }\end{array}$ & UCL, $107-85$ \\
\hline 645 & $1078 ?$ & Phylae intérieur du temple d'Isis & AUB, Jafet Library, $1 / 513$ \\
\hline 646 & 1082 & $\begin{array}{l}\text { Philae Vue d'ensemble de colonnude[sic] } \\
\text { temple d'Isis }\end{array}$ & AGO, 2008/121.33 \\
\hline 647 & 1082 & Phylae Le Kiosque d'Isis & Gr. Inst. 4114 \\
\hline 648 & 1083 & Philae Temple d'Isis et le Nil & UCL, 159-85 \\
\hline 649 & 1084 & {$[\ldots]$} & Gr. Inst. 6050 \\
\hline 650 & 1086 & Phylae porte coté est du temple Isis & Gr. Inst. 6047 \\
\hline 651 & 1087 & Phylae Interieur[sic] de la Bibliotheque & Gr. Inst. 6048 \\
\hline 652 & $1087 ?$ & Jerusalem[sic] Pierre de l'onction & BnF, 40492256, EO-487-BOITE FOL B \\
\hline 653 & 1089 & Wadi Halfah 2 me cataracte & UCL, 307-91 \\
\hline 654 & $1091 ?$ & ( & $\mathrm{BnF}, 40588367$, MFILM SG W-115 \\
\hline 655 & 1093 & (Jerusalem)[sic] Prison de Jesus Christ & GEH, 1973:0230:0008 \\
\hline 656 & 1095 & (Jerusalem)[sic] Interieur[sic] de la Sainte-Croix & GEH, 1973:0230:0009 \\
\hline 657 & 1097 & (Jérusalem) Ruelle allant au palais d'Hèrode & AUB, Jafet Library, 1/369 \\
\hline 658 & 1099 & (Jérusalem) Arc de l'Ecce Homo & AUB, Jafet Library, 1/371 \\
\hline 659 & 1101 & Tombeaux de Rachel pris Bethlehem & GEH, 1973:0230:0035 \\
\hline 660 & 1101 & Tombeau de Rachel près Bethlehem & AUB, Jafet Library, 1/287 \\
\hline 661 & 1101 & $\begin{array}{l}\text { (Jérusalem) Voie douloureuse et maison de } \\
\text { Pilate }\end{array}$ & AUB, Jafet Library, $1 / 370$ \\
\hline 662 & 1103 & Colonie Allemande sur la route de Bethlehem & AUB, Jafet Library, $1 / 273$ \\
\hline 663 & 1105 & Hopital Anglais, route de Bethlehem & UCL, $108-85$ \\
\hline 664 & 1106 & Mar Elias, route de Bethlehem & UCL, $109-85$ \\
\hline 665 & 1113 & $\begin{array}{c}\text { Bethlecem Interieur[sic] du l'eglise[sic] de ka } \\
\text { Vabiase[...] }\end{array}$ & $\mathrm{BnF}, 40492256$, EO-487-BOITE FOL B \\
\hline
\end{tabular}




\begin{tabular}{|c|c|c|c|}
\hline & A & B & $\mathrm{C}$ \\
\hline 666 & 1113 & Jericho Panorama [Ariha] & AUB, Jafet Library, 1/322 \\
\hline 667 & 1117 & $\begin{array}{l}\text { (Bethleem) Interieur[sic] de la Grotte de la } \\
\text { Nativitie }\end{array}$ & GEH, 1973:0230:0033 \\
\hline 668 & 1118 & Bethlehem, Entrée de la Grotte du Laib[...] & AUB, Jafet Library, 1/285 \\
\hline 669 & 1119 & Intérieur de la Grotte du Lait & AUB, Jafet Library, 1/280 \\
\hline 670 & 1121 & Environs of Bethlehem [The Pool of Soloman] & GEH, 1973:0230:0034 \\
\hline 671 & 1121 & Vasques de Salomon près Bethlehem & AUB, Jafet Library, 1/274 \\
\hline 672 & 1128 & $\begin{array}{c}\text { Le bain a[sic] la Mer Morte [The Shore of the } \\
\text { Dead Sea] }\end{array}$ & GEH, 1973:0230:0040 \\
\hline 673 & 1130 & On the Edge of the Jordan & GEH, 1973:0230:0039 \\
\hline 674 & $113 ?$ & Vue de Jéricho [Ariha] & AUB, Jafet Library, $1 / 323$ \\
\hline 675 & 1131 & lle dans le Jordain & AUB, Jafet Library, $1 / 418$ \\
\hline 676 & 1132 & Road to Bethlehem from Jerusalem & GEH, 1973:0230:0029 \\
\hline 677 & 1135 & Montagne de la Quarantaine & AUB, Jafet Library, $1 / 523$ \\
\hline 678 & 1136 & La Fontaine d'Elisée & AUB, Jafet Library, $1 / 325$ \\
\hline 679 & 1137 & Tombeau des Apótres sur la route de Jéricho & AUB, Jafet Library, $1 / 327$ \\
\hline 680 & 1139 & Béthanie Vue Generale & Ebay, quaintday \\
\hline 681 & 1140 & Béthanie Panorama & AUB, Jafet Library, 1/268 \\
\hline 682 & 1144 & (Jerusalem) Tombeau de Juifs & AUB, Jafet Library, $1 / 350$ \\
\hline 683 & 1146 & $\begin{array}{l}\text { (Jerusalem) [The Tombs of the Kings] Tombeau } \\
\text { des Rois }\end{array}$ & GEH, 1973:0230:0027 \\
\hline 684 & 1149 & [On the road to Jaffa the Village of Emmans] & GEH, 1973:0230:0037 \\
\hline 685 & 1149 & Village d'Emmaus, route de Jaffa [Amwas] & AUB, Jafet Library, 1/299 \\
\hline 686 & 1150 & Village d'Abrigos route de Jaffa & AUB, Jafet Library, $1 / 256$ \\
\hline 687 & 1153 & [On the Road to Jaffa The town of Ramleh] & GEH, 1973:0230:0038 \\
\hline 688 & 1155 & (Jaffa) Fontaine d'Abou-Nabout & AUB, Jafet Library, $1 / 315$ \\
\hline 689 & 1157 & Bazar[sic] de Jaffa & GEH, 1973:0230:0002 \\
\hline 690 & 1158 & Maison de Saint Pierre & AUB, Jafet Library, $1 / 314$ \\
\hline 691 & 1160 & Panorama de Bethle[h]em & AUB, Jafet Library, $1 / 278$ \\
\hline 692 & 1161 & Jaffa, Vue d'Ensemble & GEH, 1973:0230:0001 \\
\hline 693 & 1162 & Jaffa prise de de[sic] mer & $\mathrm{BnF}, 40492256, \mathrm{EO}-487-\mathrm{BOITE}$ FOL B \\
\hline 694 & $1195 ?$ & [Jerusalem] & BnF, 40589747, MFILM SG WD-286 \\
\hline 695 & 1410 & Arc de triomphe, Damasc[us] & CCA, PH1987:0405 \\
\hline 696 & 1439 & [Jerusalem] & BnF, 40589747, MFILM SG WD-286 \\
\hline 697 & 1569 & Grand palmier au Medrechen & Marta Braun Coll. \\
\hline 698 & 1583 & Guezire[sic palas[sic] HotelCaire & CCA, PH1984:0145 \\
\hline 699 & 1586 & Boeuf et pyramides & CCP, T247/S14B, 78:111:019 \\
\hline 700 & 1612 & Hótel d'Angleterre & GRI, 2008_r_3_3261 \\
\hline
\end{tabular}




\begin{tabular}{|c|c|c|c|}
\hline & A & $\mathrm{B}$ & C \\
\hline 701 & 1618 & Interieur[sic] Mosquee El Azhar & The University of Tennessee \\
\hline 702 & 1619 & Vue du Nil près de Kasr-el-Nil & GRI, 2008_r_3_3245 \\
\hline 703 & 1647 & Station de chemin de fer à Heluan & GRI, 2008_r_3_3262 \\
\hline 704 & 1649 & Le sacrifice des boeufs à Sakkara & CCP, T247/S14B, 78:111:005 \\
\hline 705 & 1650 & Exportation des produit de la Haute Egypte[sic] & Gr. Inst. 6291 \\
\hline 706 & 1651 & Tombeau du [...] Sakkara & CCP, T247/S14B, 78:111:004 \\
\hline 707 & 1651 & Tombeau de Tet à Sakkara & Gr. Inst. Gardiner MSS. 28.1088 \\
\hline 708 & 1656 & Le Casino de Heluan & GRI, 2008_r_3_3264 \\
\hline 709 & 1672 & Paime de doum Kamt Egypt[sic] & Barry Iverson Coll. \\
\hline 710 & illeg & [Boys on Donkeys] & GRI, 2008_r_3_3255 \\
\hline 711 & illeg & Jerusalem[sic], prix de l'Hotel Hovarts & GEH, 1973:0230:0004 \\
\hline 712 & illeg & Jerusalem Via Dolorosa and House of Divas & GEH, 1973:0230:0013 \\
\hline 713 & illeg & Jerusalem, The tomb of the Virgin & GEH, 1973:0230:0014 \\
\hline 714 & illeg & $\begin{array}{l}\text { Jerusalem, From the Mount of Olives } \\
\text { (Panorama de Jerusalem No. } 3 \text { ) }\end{array}$ & GEH, 1973:0230:0015 \\
\hline 715 & illeg & $\begin{array}{l}\text { (Mosquee[sic] d'Omar interieur[sic] (le rocher)) } \\
\text { Jerusalem[sic] }\end{array}$ & GEH, 1973:0230:0016 \\
\hline 716 & illeg & Jerusalem Mosque of Omar & GEH, 1973:0230:0019 \\
\hline 717 & illeg & [Egyptian columns] & GEH, 1978:1297:0027 \\
\hline 718 & illeg & [Tomb interior with four Egyptians] & GRI, 2008_r_3_3257 \\
\hline 719 & illeg & [Cairo street] & GRI, 2008_r_3_3274 \\
\hline 720 & illeg & [Steamship at anchor] & GRI, 2008_r_3_3292 \\
\hline 721 & illeg & [Man with a white beard] & GRI, 2008_r_3_3295 \\
\hline 722 & illeg & [African boy] & GRI, 2008_r_3_4148 \\
\hline 723 & illeg & Colonnade de Temple d'isis & NYPL, 88427 \\
\hline 724 & illeg & [Caire New Hotel] & NYPL, 88430 \\
\hline 725 & illeg & Kom Ombo Temple de Sebek et Horus & NYPL, 88433 \\
\hline 726 & illeg & Charmeur des [serpents] & NYPL. 88436 \\
\hline 727 & illeg & Jeune fille en costume d'interieur[sic] & $\mathrm{BnF}, 40590054, \mathrm{FN}-7702237$ \\
\hline 728 & illeg & [Jeune fille egyptienne][sic] & $\mathrm{BnF}, 40590054, \mathrm{FN}-7702237$ \\
\hline 729 & illeg & $\begin{array}{l}\text { [femme egyptienne[sic] voilee[sic] tenant une } \\
\text { poterie a[sic] la main] }\end{array}$ & $\mathrm{BnF}, 40590054, \mathrm{FN}-7702237$ \\
\hline 730 & illeg & [Femme egyptienne[sic] voilee[sic]] & $\mathrm{BnF}, 40590054, \mathrm{FN}-7702237$ \\
\hline 731 & illeg & Charmeur de serpent & $\mathrm{BnF}, 40590054, \mathrm{FN}-7702237$ \\
\hline 732 & illeg & Repos d'un chameau & $\mathrm{BnF}, 40590054, \mathrm{FN}-7702237$ \\
\hline 733 & illeg & [Un jeune anier et sa bete] & $\mathrm{BnF}, 40590054, \mathrm{FN}-7702237$ \\
\hline 734 & illeg & Canal de Suez & BnF, $40590054, F N-7702237$ \\
\hline 735 & illeg & $\begin{array}{l}\text { Le Cairem fontaine aux ablutions a[sic] la } \\
\text { mosquee[sic] de Hassan Pacha }\end{array}$ & $\mathrm{BnF}, 40589982$, IFN- 7702164 \\
\hline
\end{tabular}




\begin{tabular}{|c|c|c|c|}
\hline & A & B & C \\
\hline 736 & illeg & $\begin{array}{l}\text { Le Caire rue de la mosquee[sic] de Touloun } \\
\text { Moucharabis }\end{array}$ & BnF, 40589982, IFN- 7702164 \\
\hline 737 & illeg & [Le Caire] & $\mathrm{BnF}, 40589982$, IFN- 7702164 \\
\hline 738 & illeg & Master Lolo a[sic] la chasse au crocodile & BnF, 40589982, IFN- 7702164 \\
\hline 739 & illeg & Le Sphinx et la pyramide de Chephren & BnF, 40589982, IFN- 7702164 \\
\hline 740 & illeg & Porte de la grande pyramide de Cheops & $\mathrm{BnF}, 40589982$, IFN- 7702164 \\
\hline 741 & illeg & Alexandrie moulins de Mex & $\mathrm{BnF}, 40589982$, IFN- 7702164 \\
\hline 742 & illeg & Rade de Port-said[sic] & $\mathrm{BnF}, 40589982$, IFN- 7702164 \\
\hline 743 & illeg & $\begin{array}{l}\text { Groupe de dattiers a[sic] La fontaine de Moise } \\
\text { pres[sic] de Suez }\end{array}$ & BnF, 40589982, IFN- 7702164 \\
\hline 744 & illeg & $\begin{array}{l}\text { Fontaine de Moise el Suez [groupe d'hommes } \\
\text { et de chameaux au pied de palmiers] }\end{array}$ & $\mathrm{BnF}, 40589982$, IFN- 7702164 \\
\hline 745 & illeg & Voiture arabe charette tire[sic]e par un ane[sic] & $\mathrm{BnF}, 40589982$, IFN- 7702164 \\
\hline 746 & illeg & Anier et moucharabi & $\mathrm{BnF}, 40589982$, IFN- 7702164 \\
\hline 747 & illeg & Chameau du desert[sic] & $\mathrm{BnF}, 40589982$, IFN- 7702164 \\
\hline 748 & illeg & Caravane de chameaux & BnF, 40589982 , IFN- 7702164 \\
\hline 749 & illeg & Nubie Bicharines & BnF, 40589982, IFN- 7702164 \\
\hline 750 & illeg & Nubie Bicharine & BnF, 40589982, IFN- 7702164 \\
\hline 751 & illeg & Rade de Port-Said[sic] & $\mathrm{BnF}, 40589991, \mathrm{IFN}-\mathbf{7 7 0 2 1 7 3}$ \\
\hline 752 & illeg & Canal & BnF, 40589991, IFN- 7702173 \\
\hline 753 & illeg & Tombeaux des Mameluks et citadelle & $\mathrm{BnF}, 40589991, \mathrm{FN}-7702173$ \\
\hline 754 & illeg & Passage au Pont de Kasr-el-Nil & BnF, 40589991, IFN- 7702173 \\
\hline 755 & illeg & Le Sphinx decouvert[sic] & BnF, 40589991, IFN- 7702173 \\
\hline 756 & illeg & Fontaine de Moise[sic] & $\mathrm{BnF}, 40589991, \mathrm{IFN}-7702173$ \\
\hline 757 & illeg & $\begin{array}{l}\text { Panorama d'Alexandrie, pres[sic] du fort } \\
\text { Napoleon[sic] }\end{array}$ & BnF, 40589991, IFN- 7702173 \\
\hline 758 & illeg & Femmes arabes portant de l'eau & $\mathrm{BnF}, 40589991, \mathrm{FNN}-7702173$ \\
\hline 759 & illeg & Yach Anglais a[sic] toussoux & AUC, 19th Century photographs \\
\hline 760 & illeg & Quai de Port-Said & AUC, 19th Century photographs \\
\hline 761 & illeg & Femmes arabes portant de l'eau & BnF, 40589991, IFN-7702173 \\
\hline 762 & illeg & Egypte[sic] colonade souteraine[sic] & NYPL, 88438 \\
\hline 763 & illeg & Vue d'Alexandrie[...] & NYPL, 81453 \\
\hline 764 & illeg & Les boeufs dans le Nil & NYPL, 81456 \\
\hline 765 & illeg & [Study of water buffaloes] & NYPL, 81457 \\
\hline 766 & illeg & [Pyramid, trees and camels with handlers] & NYPL, 87083 \\
\hline 767 & illeg & Bethlehem, vue d'ensemble & NYPL, 119077 \\
\hline 768 & illeg & [Jerusaiem. Church of the Holy Sepulchre] & AUB, Jafet Library, 1/375 \\
\hline 769 & illeg & (Jérusalem) Mosquée d'Omar et Quartier Turc & AUB, Jafet Library, $1 / 394$ \\
\hline 770 & illeg & [Jérusalem] & AUB, Jafet Library, $1 / 410$ \\
\hline
\end{tabular}




\begin{tabular}{|c|c|c|c|}
\hline & A & $\mathrm{B}$ & $\mathrm{C}$ \\
\hline 771 & illeg & $\begin{array}{c}\text { Vue generale[sic] des Tombeaux des } \\
\text { Mamelouks Caire }\end{array}$ & UCL, 347-93 \\
\hline 772 & illeg & Port et radde de Port Said[sic] & UCL, 305-91 \\
\hline 773 & illeg & $\begin{array}{l}\text { Personnages avec des ânes devant une } \\
\text { palmeraie[sic] }\end{array}$ & Musée d'Orsay, PHO 1996527 \\
\hline 774 & Unknown & [Water Buffaloes in Nile] & GRI, 2008_r_3_3006 \\
\hline 775 & Unknown & [Sailboats near the bank of the Nile] & GRI, 2008_r_3_3243 \\
\hline 776 & Unknown & [The road of Sphinx] & AGO, 2008/ 121.18 \\
\hline 777 & Unknown & H. M. troopship Euphrates & GRI, 2008_r_3_3248 \\
\hline 778 & Unknown & [Ships in dock] & GRI, 2008_r_3_3249 \\
\hline 779 & Unknown & [The road of Sphinx] & AGO, 2008/ 121.24 \\
\hline 780 & Unknown & [Le Sphinx] & AGO, 2008/ 121.29 \\
\hline 781 & Unknown & Place de Lesseps à Port Saĩd & GRI, 2008_r_3_3253 \\
\hline 782 & Unknown & Alexandrie & GRI, 2008_r_3_3267 \\
\hline 783 & Unknown & Village arabe à Port Saìd & GRI, 2008_r_3_3269 \\
\hline 784 & Unknown & [Tree of the virgin] & GRI, 2008_r_3_4151 \\
\hline 785 & Unknown & Dinar arabe & GEH, 1988:0355:0001 \\
\hline 786 & Unknown & Marchand d'eau & GEH, 1988:0355:0002 \\
\hline 787 & Unknown & Ensemble du Ramseum Thebes & GEH, 1988:0355:0003 \\
\hline 788 & Unknown & Statue de Ramses a[sic] Lougsor[sic] & GEH, 1988:0355:0004 \\
\hline 789 & Unknown & Karnak Grande porte de [...]olomee & GEH, 1988:0355:0005 \\
\hline 790 & Unknown & [...] de mariage arabe & GEH, 1988:0355:0006 \\
\hline 791 & Unknown & Femme Turque Voilee[sic] & GEH, 1988:0355:0007 \\
\hline 792 & Unknown & Haute Egypte[sic] - Bateau postal & MET, 1970.760 .3 \\
\hline 793 & Unknown & Edfou Interieur[sic] du temple de Horous & MET, 1981.1194 .9 \\
\hline 794 & Unknown & Colonnade du temple & MET, 1981.1194.10 \\
\hline 795 & Unknown & Medinet Abou Premier piliers a caryatides & MET, 1981.1194.11 \\
\hline 796 & Unknown & Famille bichurine & MET, 1981.1194.12 \\
\hline 797 & Unknown & Chadoufs, Haute Egypte[sic] & MET, 1981.1194 .13 \\
\hline 798 & Unknown & $\begin{array}{l}\text { Groupe de bicharis au champ des cannes de } \\
\text { sucre }\end{array}$ & MET, 1981.1194.14 \\
\hline 799 & Unknown & Tourneur du bois & MET, 1981.1194.15 \\
\hline 800 & Unknown & Voiture arabe & MET, 1981.1194.16 \\
\hline 801 & Unknown & [Two Girls in Front of Wall] & MET, 1981.1194 .17 \\
\hline 802 & Unknown & Venteuse d'eau & MET, 1981.1194 .18 \\
\hline 803 & Unknown & Coifeur[sic] arabe & MET, 1981.1194.19 \\
\hline 804 & Unknown & Famille fellahine & MET, 1981.1194 .20 \\
\hline 805 & Unknown & An[sic] du Cous & MET, 1981.1194.21 \\
\hline
\end{tabular}




\begin{tabular}{|c|c|c|c|}
\hline & A & B & C \\
\hline 806 & Unknown & Marchand de noix & MET, 1981.1194.22 \\
\hline 807 & Unknown & [Boat on the Nile] & MET, 1981.1194 .23 \\
\hline 808 & Unknown & [Turkish Woman] & AlF, 0010sa00064 \\
\hline 809 & Unknown & Diner arabe & AlF, 0010sa00065 \\
\hline 810 & Unknown & [By the shadow] & AlF, 0010sa00132 \\
\hline 811 & Unknown & [Two Abyssinians] & AlF, 0010 sa00133 \\
\hline 812 & Unknown & Tourneur du bois & AlF, 0010 sa00134 \\
\hline 813 & Unknown & [Snake Charmer] & AlF, 0010 sa00135 \\
\hline 814 & Unknown & [Whirling Dervishes] & AIF, 0010 sa00137 \\
\hline 815 & Unknown & Chadoof a[sic] la Haute Egypt & AlF, 0010 sa00142 \\
\hline 816 & Unknown & [A water seller and a woman] & AlF, 0010 sa00138 \\
\hline 817 & Unknown & [Three men] & AlF, 0010sa00139 \\
\hline 818 & Unknown & [Nubian] & AlF, 0010 sa 00140 \\
\hline 819 & Unknown & [Carriage transporting Arab women] & AIF, 0010sa00199 \\
\hline 820 & Unknown & [Arab women carrying water from the Nile] & AlF, 0010 sa00079 \\
\hline 821 & Unknown & [Fighting the crocodile] & AlF, 0010 sa00041 \\
\hline 822 & Unknown & [Water carriers] & AlF, 0010sa00141 \\
\hline 823 & Unknown & [Salam-Alik] & AlF, 0010sa00054 \\
\hline 824 & Unknown & [Water carrier] & AIF, 0010 sa00055 \\
\hline 825 & Unknown & [Nubian family] & AlF, 0010 sa00056 \\
\hline 826 & Unknown & [Peasants] & AlF, 0010 sa000058 \\
\hline 827 & Unknown & [Grand Turkish Dervish] & AlF, 0010 sa000036 \\
\hline 828 & Unknown & [Initerant coffee maker] & AlF, 0010 sa00053 \\
\hline 829 & Unknown & [Crocodile merchants] & AlF, 0010 sa00057 \\
\hline 830 & Unknown & [Peasants on the river bank] & AlF, 0010sa00059 \\
\hline 831 & Unknown & [Woman in traditional clothing holding a jar] & AlF, 0010 sa00060 \\
\hline 832 & Unknown & [Arab women carrying water from the Nile] & AlF, 0010 sa00061 \\
\hline 833 & Unknown & [Arab woman carrying a jar] & AlF, 0010sa00062 \\
\hline 834 & Unknown & [Fellah woman and a child] & AlF, 0010 sa00063 \\
\hline 835 & Unknown & [Bishareen Family Portrait] & $\begin{array}{l}\text { The Oriental Institute of University of } \\
\text { Chicago, lost egypt catalog }\end{array}$ \\
\hline 836 & Unknown & Cairo Panorama I & Harvard University Library \\
\hline 837 & Unknown & [Arab Singers] & Harvard University Library \\
\hline 838 & Unknown & [The grand hall and obelisk at Karnak] & Harvard University Library \\
\hline 839 & Unknown & [Place Muhammad Ali] & Harvard University Library \\
\hline 840 & Unknown & [Thebes Entry to the Tomb of the King] & Harvard University Library \\
\hline
\end{tabular}




\begin{tabular}{|c|c|c|c|}
\hline & A & B & C \\
\hline 841 & Unknown & [Colonnade of the Temple at Luxor] & Harvard University Library \\
\hline 842 & Unknown & Le Sphinx et Pyramide & Ebay, photobazaar \\
\hline 843 & Unknown & Caire. Ziker Fete[sic] arabe & $\begin{array}{l}\text { The University of Texas at Austin, } \\
964: 3410: 0001\end{array}$ \\
\hline 844 & Unknown & [...] pyramides & $\begin{array}{l}\text { The University of Texas at Austin, } \\
964: 3410: 0002\end{array}$ \\
\hline 845 & Unknown & [Man standing on top ofSphynx] & Collection of François Lepage, Paris \\
\hline 846 & Unknown & [Four men standing infront of the Sphynx] & Collection of François Lepage, Paris \\
\hline 847 & Unknown & [Thebes colosses de Memnon] & AGO, 2008/ 121.5 \\
\hline 848 & Unnumbered & Philae Vue prise de l'ile Bique & GEH, 1978:1297:0015 \\
\hline 849 & Unnumbered & Quai du Port-Said[sic] & GEH, 2001:1522:0001 \\
\hline 850 & Unnumbered & [Date merchant] & NYPL, 88443 \\
\hline 851 & Unnumbered & Untitled & Marta Braun Coll. \\
\hline 852 & Unnumbered & $\begin{array}{l}\text { Obelisque[sic] d'Heliopolis (Matarie No.21 } \\
\text { Pluotag Artisticine[...]) }\end{array}$ & Marta Braun Coll. \\
\hline 853 & Unnumbered & Gourbe el Guins Crocodil[....] & Marta Braun Coll. \\
\hline 854 & Unnumbered & Entrée du canal a[sic] Port-Said & Marta Braun Coll. \\
\hline 855 & Unnumbered & Entrée de Port-Said[sic] & CCP, T247/S14B, 78:111:002 \\
\hline 856 & Unnumbered & Rue du $[\ldots]$ à Port-Said & $\mathrm{CCP}, \mathrm{T} 247 / \mathrm{S} 14 \mathrm{~B}, 78: 111: 012$ \\
\hline 857 & Unnumbered & [Le Sphinx] & AUC, 19th Century photographs \\
\hline 858 & Unnumbered & Untitled & AUC, 19th Century photographs \\
\hline 859 & Unnumbered & Untitled & AUC, 19th Century photographs \\
\hline 860 & Unnumbered & Untitied & AUC, 19th Century photographs \\
\hline 861 & Unnumbered & Untitled & AUC, 19th Century photographs \\
\hline 862 & Unnumbered & [Egyptiennes] & BnF, 40492256, EO-487-BOITE FOL B \\
\hline 863 & Unnumbered & Untitled & $\mathrm{BnF}, 40492256$, EO-487-BOITE FOL B \\
\hline 864 & Unnumbered & [...] de la grande Pyramide & $\mathrm{BnF}, 40492256$, EO-487-BOITE FOL B \\
\hline 865 & Unnumbered & appartement de chant & $\mathrm{BnF}, 40492256$, EO-487-BOITE FOL B \\
\hline 866 & Unnumbered & Drague Derochuese N'14 & BnF, 40492256, EO-487-BOITE FOL B \\
\hline 867 & Unnumbered & Canal de Suez & $\mathrm{BnF}, 40492256$, EO-487-BOITE FOL B \\
\hline 868 & Unnumbered & Port Said et stations du canal & $\mathrm{BnF}, 40492256$, EO-487-BOITE FOL B \\
\hline 869 & Unnumbered & vue d'Somailia et Hotel Victoria & BnF, 40492256, EO-487-BOITE FOL B \\
\hline 870 & Unnumbered & Untitled & $\mathrm{BnF}, 40492256, \mathrm{EO}-487-\mathrm{BOITE}$ FOL B \\
\hline 871 & Unnumbered & Malabar a[sic] Chartier II & BnF, 40492256, EO-487-BOITE FOL B \\
\hline 872 & Unnumbered & Grande courte[sic] d El [...] & BnF, 40492256, EO-487-BOITE FOL B \\
\hline 873 & Unnumbered & [Zangaki Freres Suez Canal plan] & BnF, 40492256, EO-487-BOITE FOL B \\
\hline 874 & Unnumbered & Pont du Kasr-el-nil-caire & GEH, 1986:0309:0089 \\
\hline
\end{tabular}




\section{APPENDIX D:}

\section{HOUSING MATERIALS}

All housing materials were ordered from Carr McLean Archival \& Museum Supplies.

Items:

45 albumen prints

Housing: (Sleeves)

Archival Polyester Envelopes (3 mil)

M95-431 9" x 12" (\$39.70 pkg)

2 packages ( 25 per package)

(Backing Board) Alpharag Museum Board with Microchamber Technology

Colour: white ( 5 sheets per package)

M8649 1-Ply $32^{\prime} \times 40^{\prime} \quad(\$ 29.95 \mathrm{pkg})$

2 packages

(Hollinger Drop 3"H x 12-1/2"W x 9-1/2"D

Front Print Box) MH-10610 Hollinger Grey (\$14.85 each)

Item: $\quad$ Album shell

Housing: (Hollinger 1-1/2"H x 20-1/2"W x 16-1/2"D

Drop Front MH 10640 Hollinger Grey (\$24.35 each

Print Box) 